\title{
المسؤولية المدنية عن همارسة الإضراب عن العمل
}

\author{
shel \\ د/ سامح عبد الواحد التهامى \\ أستاذ القانون المدني المساعد بكسليتالحقوق \\ جامعت الزقازيق
}




\section{الاقدهمة}

إن أحــ أهـــ الإشـكاليات التـي تواجـه المجتمـع المـصري هـي عـدم الممارســة

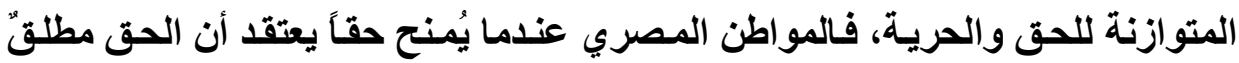
يُمارس بلا قيود، وعندما يمارس حريـة فإنـه يمارسـها بـلا ضوابط؛ معتقداً أن ذلك هو

$$
\text { مقصود هذه الحرية. }
$$

وأحد أهم الحقوق التي مورست دون ضابط هو الحق في الإضراب، خاصـة بعد

إندلاع ثورة الخامس والعشرين من يناير I 1 ـ ب، حيث شـهت مصر إضرابات شبه

يومية في كثير من القطاعات الاقتصادية العامة والخاصة.

والواقع أن الحق في الإضراب يتناز عه فلسفتان، الأولى أن هذا الحق هو حق

أساسي من حقوق الإنسان الاقتصادية والاجتماعية، فلا يجوز حظره أو تقييده، أمسا القلسفة الثانية فتري أن الإضراب هو ترف لا تتحمله اقتصاديات الدول النامية وأنها يجب تقييده بشكل كبير حتى لا يؤدى إلى فوضى في المنشآت الاقتصادية تؤدى لتدهور

(الاقتصاد بتلك الدول. (1)

أولاًا-أهـهية البحث:

نصت المواثيق الدولية على حق العامل في الإضراب عن العمل، فقد نصت

المـادة ^/1 مـن العهــ الـدولى الخـاص بـالحقوق الاقتصادية والاجتماعيـة والثقافيـة

(1) Michel de PONCINS, Le tabou du droit de grève, Le Québécois Libre, 15 février 2012, $\mathrm{N}^{\circ} 297$, disponible sur:www.quebecoislibre.org. 
الصادر عـام 979 أبأن تتعهد الدول الأطراف في هذا العهد بكفالة حق الإضراب، شريطة ممارسته وفقاً لقوانين البلا المعنى.

وكذلك نـصت المـادة هـ/T مـن الميثاق العربـي لحقوق الإنسان الـصادر عـام

؟ . . ب على أن تكفل كل دولة الحق في الإضراب في الحدود التي ينص عليها التشريع

الناقة.

ونص الاستور المصري الصادر عام \& ا ـ ب على الحق في الإضراب في المادة

الخامسة عشرة منه، حيث نصت على (الإضراب السلمى حق ينظمه القانون).

وحيث إن الدستور قد نص على قيام المشرع بتنظيم الحق في الإضراب، فيترتب

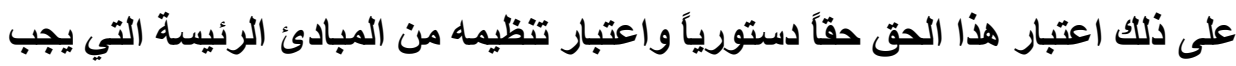

النص عليها في قانون العمل. (1)

فالاستور عندما يمنح حقاً، يأتي التشريع العادى ليهذب هذا الحق، وذلك بوضع

ضوابط ممارسته والجزاء على مخالفة هذه الضوابط، حتى تكون ممارسـة هذا الحق ممارسة سليمة غير ضارة.

وقد نص قانون العمل المصري () على حق العامل في الإضراب وعلى بعض

القواعد التي تنظمه، وذلك في المواد من ب9 19 إلى ه9 19.

(1) Antoine JEAMMAUD, Les principes dans le droit français du travail, Droit social, Dalloz, 1982, p. 618 -629.

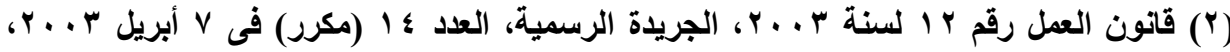


وبالتـالي فـالحق في الإضـراب هو حق دستوري، إلا إن ممارسـة العامـل لهـذا

الحق قد يترتب عليه كثير من الأضرار التي يمكن أن تصيب رب العمل أو تصيب العمال

الآخرين غير المضربين عن العمل تصيب الغير من عملاء المنشأة.

فيظل من حق المضرور أن يطالب بتعويض الأضرار التي أصـابته والتي قد

تكون مترتبة عن هذا الإضراب، ولكن الحكم على العامل بتعويض الأضرار المترتبـة عن إضرابه عن العمل قد يعد جزاءً مدنياً يطبق عليه نتيجة إضرابه عن العمل ممـا قد يؤدى إلى تعطيل هذا الحق الاستوري.

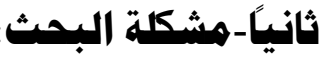

يري العمـال والنقابـات العمالية أن الحق في الإضراب هو إحدى أهم الوسـائل

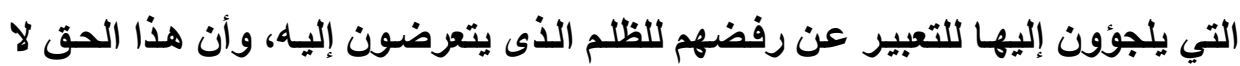
يجوز تقييده بأى قيا ولا يجوز التعويض عن الأضرار المترتبة عليه.

ولكن من ناحيـة أخري فالإضـراب هو واقعة قانونيـة لا يجوز اسـتنـاؤها مـن

تطبيق أحكام القـانون، فيجب أن يتقيد الإضراب بـالقيود القانونيـة الواردة في قانون

العمل وبالقواعد العامة الواردة في القانون المدنى والخاصة بالمسؤولية المدنية.

فالمشكلة الرئيسة في هذه الدراسـة أنتـا نبحث مـدى إمكانية التعويض عن ممارسة حق دستوري يعتبر من حقوق الإنسان الاقتصادية والاجتماعية، ولذلك فالحكم بمدى التزام العامل أو النقابة العمالية بتعويض الضرر المترتب عن الإضراب عن العمل من عدمه هو أمر دقيق جداً؛ لأنه يمس حقاً أساسياً من حقوق الإنسان.

ولكن مـن ناحيـة أخري لا يمكن أن نغفل حق المـضرور في الحصول على

تعويض عن الأضرار التي أصابته من جراء الإضراب عن العمل، وإلانكون قد أغقلنـا مباً هاماً من مبادئ القانون المدنى وهو الإلتزام بجبر الضرر. 
فتثير المسؤولية المدنية عن ممارسة الإضراب عدة تساؤلات هي: 1 - هل يجوز تطبيق قواعد المسؤولية المدنية للتعويض عن الأضرار الناتجة عن

$$
\text { ممارسة حق دستوري؟ }
$$

r - متى تعتبر ممارسة الإضراب ممارسة غير مشروعة؟ وما هي صور الخطأ الذي

يمكن أن يرتكبه العامل أو النقابة العمالية أثناء ممارسة الحق في الإضراب؟

rـ هـل تثيـر الممارسـة غيـر المسشروعة لحـق الإضـراب المسؤولية العقديـة أم

المسؤولية التقصيرية؟

ـ - متى تعتبر ممارسة الإضراب تعسفية؟ وهل من الممكن إقامـة مسؤولية العامـل المدنية عن الأضـرار المترتبـة عن إضـرابه التعسفى عن العـل حتى ولـو لـم

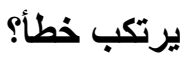

هـ هل المسؤولية عن تعويض الضرر يمكن أن تكون مسؤولية جماعية على جميع العمال المشتركين في الإضر اب أم مسؤولية فردية؟

جـ هل يمكن إقامـة المسؤولية المدنية للنقابـة العمالية عن الأضرار المترتبـة عن

$$
\text { الإضر اب الأى دعت إليه ونظمته؟ }
$$

V- متى تعتبر ممارسة النقابة العمالية للإضر اب ممارسة تعسفية؟ وهل من الممكن إقامة مسؤولية النقابة المدنية عن الأضرار المترتبة على الممارسـة التعسفية

$$
\text { لـلإضر }
$$

\section{ثالثًا-هنهج البحث:}

حتى نجيب على هذه التساؤلات فسوف نرجيع إلى القواعد العامـة فى القـانون المدنى المصري لنبحث مدى إمكانية مساعلة النقابة العمالية أو العامل مدنياً في حالـة إلة 
إصابة الغير بضرر من جراء إضرابه عن العمل، وذلك في ضوء القواعد الواردة في

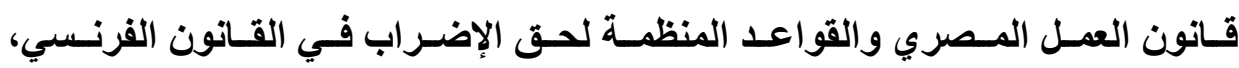
ومستعينين بكثير من أحكام محكمة النقض الفرنسية في هذا الأمر. رابعًا-خطة البمث:

حتى نتناول المسؤولية المدنية عن ممارسة الحق في الإضراب، فيجب أن نبحث مسؤولية النقابـة العماليـة عن أضرار الإضراب الذى دعت إليه ونظمته، ومسؤولية العامل عن الأضرار المترتبة عن إثتراكه في الإضراب. ويناءً على ذلك فسوف نقوم بتقسيم هذه الدراسة إلى: الفصل الأول: ماهية الإضراب. الفصل الثاني: المسؤولية المدنية للنقابة العمالية عن ممارسة الإضراب. الفصل الثالث: المسؤولية المدنية للعامل عن ممارسة الإضراب. 


\section{الفصل الأول \\ هاهية الإضراب}

\section{تمهيد وتقسيم:}

وفقاً لنص المادة ب 19 من قانون العمل المصري فإن العمال لهم حق الإضراب

السلمى، ويكون إعلانه وتنظيمه من خلال منظماتهم النقابية دفاعا عن مصالحهم

المهنية والاقتصادية والاجتماعية، وذلك في الحدود وطبقا للضوابط والإجراءات

$$
\text { المقررة في هذا القانون. }
$$

فالمشرع المصرى قد أقر بحق العمال فى الإضراب عن العمل ولكنهـه وضع لهذا

$$
\text { الحق ضوابط وإجر اءات لممارسته. }
$$

فالحق في الإضر اب هو حق دستوري، ولكن هذا الحق ليس بحق مطلق بل يجب

أن تكون هناك ضوابط لممارسته حتى يكون متو افقاً مـع بقية الحقوق والحريـات التى

لهـا نفس القيمـة الدستورية مثل حريـة العمل وحق الملكيـة، فـالتوفيق بين الحقوق

المتعارضة لا يؤدي لإنكار الحق أو منعه ولكن فقط تنظيم ممارسته. ( )

وتطبيقاً لألك، فقد أكد المجلس الاستورى الفرنسي على هذا المعنى عندما قرر

أنه (عندما يقوم المشرع بتنظيم الحق فى الإضراب، فإن مهمته تكون بإجراء الموازنـة

(1) Birame DIOUF, Les Responsabilités à l'occasion des conflits collectifs de travail : une étude du droit sénégalais des conflits collectifs à la lumière du droit français, Thèse pour le Doctorat d'Etat en droit, Fac de Droit, Univ de Cergy-Pontoise, 2010, P 60. 
بين المصالح المهنية ــ التى يهدف الإضر اب للافاع عنهـاـ وبين المصلحة العامـة التى يمكن أن يعتدى الإضراب عليها). (1)

والقيود التي يجوز وضعها على الحق في الإضراب هي القيود اللازمة لضمان

احترام حقوق وحريات الأفراد الآخرين، أو لحماية النظام العام أو الأمن القومي أو لإدير

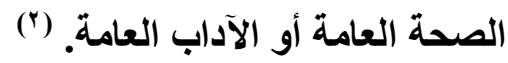

فهذا الإضراب يجب أن يكون مقيداً بضوابط معينة، بحيث تتم ممارسة هذا الحق

$$
\text { في إطار هذه الضوابط حتى تكون هذه الممارسة مشروعة. }
$$

حتى نقوم بتناول ماهيـة الحق في الإضراب، فسوف نتنـاول المقصود من هذا

الحق وعناصره وضوابط ممارسته، وذلك من خلال تقسيم هذا الفصل إلى:

$$
\text { المبحث الأول:تعريف الإضراب. المبحث الثاني: عناصر الإضراب. }
$$

(1) CC, décision $n^{\circ}$ 2012-650 DC du 15 mars 2012, J.O du 20 mars 2012, p 5028, texte $n^{\circ} 4$ Recueil, p. 149, et disponible sur: www.conseilconstitutionnel.fr.

(2) Birame DIOUF, Les Responsabilités à l'occasion des conflits collectifs de travail, Op.cit, $P$ ฯ. 


\section{المبحث الأول

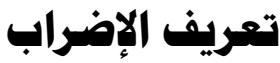

تقوم فكرة الإضراب على أنه لا يكفى الاعتر اف للعمـال بحقوقهم قبل رب العمل وإعطاؤهم الحق فى المفاوضة الجماعية مع رب العمل، ولكن يجب أن يمتلكوا الأداة التى تسمح لهم بالضغط على رب العمل لتتفيذ مطالبهم، أحد أهم هذه الوسـائل هو

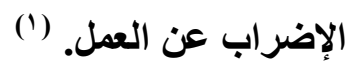

سنتناول تعريف الإضر اب فى كل من القانون الفرنسي والقانون المصرى، كل

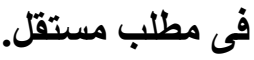

\section{المطلب الأول}

تعريف الإضراب فى القانون الفرنسي

لم يضع المشرع الفرنسي تعريفاً للاضراب، وترك وضع التعريف لاجتهادات

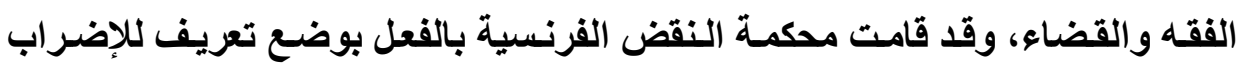

استقرت عليه فى الكثير من أحكامها.

(1) Alain SUPIOT, Revisiter les droits d'action collective, Droit Social, 2001, nº 7-8, pp. 687-704. 
فالإضراب- وفقاً لتعريف محكمة النقض الفرنسيةــ هو توقف العمـال كلياً عن

العمل للضغط على صاحب العمل بهدف تلبية مطالب مهنيـة يستطيع صساحب العمل أن

ومن ناحية أخرى فقد تصدى الفقه الفرنسي من جانبه لتعريف الإضراب، حيث

يرى رأي فى الفقه الفرنسي أن الإضراب هو وسيلة ضغط يستخدمها العمال للتعبير عن

(ץ) رأيهم وللافاع عن مصالحهم المهنية.

ويرى رأي آخر أن الإضراب هو قيام العـال بـالتوقف عن العمل رغماً عن رب

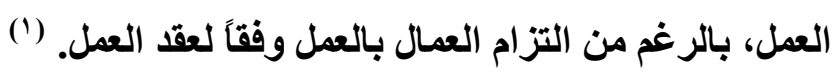

(1) Cass. Soc, 21 octobre 2009, $\mathrm{N}^{\circ}$ de pourvoi: 08-14490, Bull. civ. V, $\mathrm{n}^{\circ} 225$, et disponible sur: www.legifrance.gouv.fr.

- Cass. Soc, 23 octobre 2007, $N^{\circ}$ de pourvoi: 06-17802, Bull. civ. V, $\mathbf{N}^{\circ}$ 169. et disponible sur: www.legifrance.gouv.fr.

- Cass. Soc, 2 février 2006, $N^{\circ}$ de pourvoi: 04-12336, Bull. civ. V No 52 p. 46 . et disponible sur: www.legifrance.gouv.fr.

- Cass. Soc, 23 janvier 1969, Bull. civ. V, p. 41, n50 . et disponible sur: www.legifrance.gouv.fr.

- Cass. Soc, 18 janvier 1995, Bull. civ. V, No 27 p. 18. et disponible sur: www.legifrance.gouv.fr.

- Cass. Soc, 18 juin 1996, Bull. civ, $V, N^{\circ} 243$ p. 171. et disponible sur: www.legifrance.gouv.fr.

- Cass. Soc, 26 janvier 2000, Bull. civ, $\mathrm{V}, \mathrm{N}^{\circ} 38$, p. 28. et disponible sur: www.legifrance.gouv.fr.

- Cass. Soc, 18 décembre 2001, Bull. civ, $\mathrm{V}, \mathrm{n}^{\circ}$ 387, p. 311. et disponible sur: www.legifrance.gouv.fr.

(2) Céline LAURICHESSE, La grève en droit international privé, Thèse Pour obtenir le grade de Docteur, Faculté de droit et de science politique, Université de Bourgogne, 2014, P 33, nº 18. 


\section{الاطلب الثاني \\ تعريف الإضراب فى القانون المصري}

إذا كـان المشرع المـصرى قـ أقر بمشروعية الإضـراب فـى الاستور ووضـع

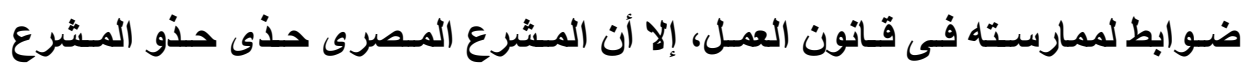
الفرنسي فى عدم وضع تعريف للإضراب تاركاً ذللك للفقه والقضاء.

وعدم وضـع تعريف للإضـراب من جانب المشرع هو أمر محمود؛ لأنـه يفتح

الباب أمام اجتهادات الفقه والقضاء لوضع التعريف المناسب الذَى يواكب التطورات التى تصاحب ممارسة الحق فى الإضراب.

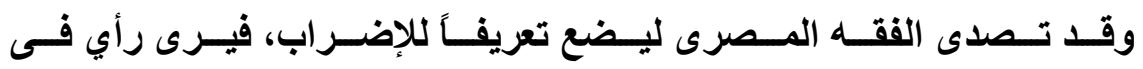

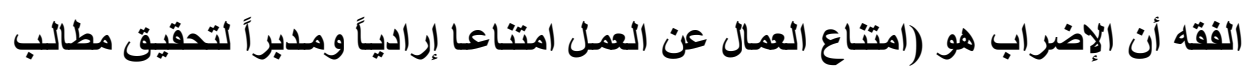

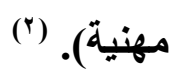

ويـرى رأى آخــر أن الإضــراب هــو (امتــــاع العـــال عـن العــل امتتـاعـــا

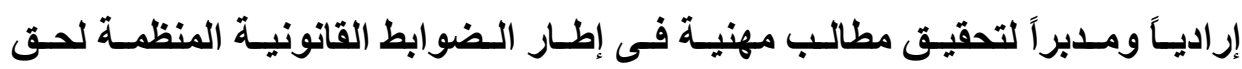

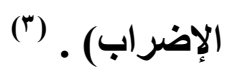

(1) Paul DURAND, La Grève et le lock-out en droit français, en Collection du droit du travail: Le droit du travail dans la communauté, Luxembourg, 1961, p 207.

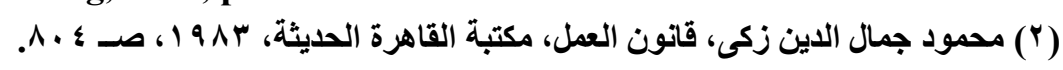

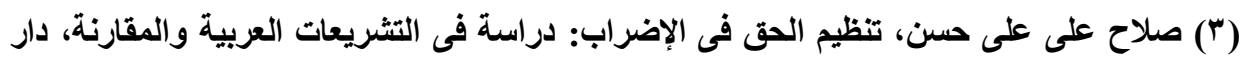

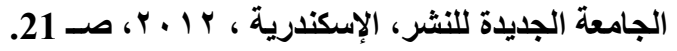


ويرى رأي آخر أن الإضراب هو (امتــاع العمـال عن العمل، بصفة جماعيـة

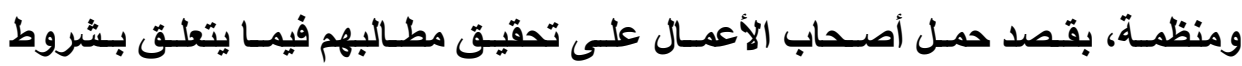

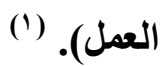

ويرى رأي آخر أن الإضراب هو (امتناع جميع العمال أو فريق منهم عن أداء

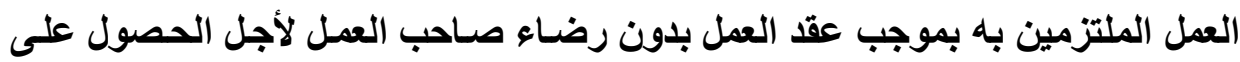

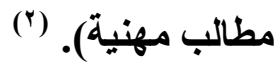

ويرى رأي آخر أن الإضراب هو (توقف مجموعة من العمال عن العمل بقصد

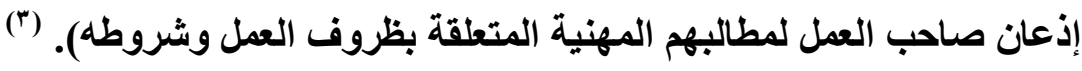

ويرى رأي آخر أن الإضراب هو (التوقف بصورة جماعية ومدبرة عن العمل

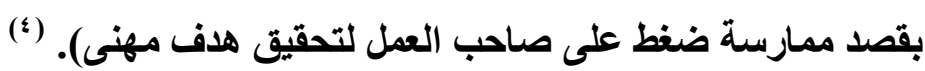
ويرى رأي آخر أن الإضراب هو (توقف جماعى مدبر عن العمل يهلف إلى تائيد

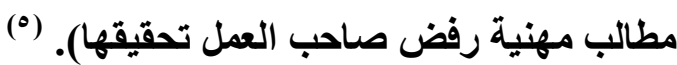

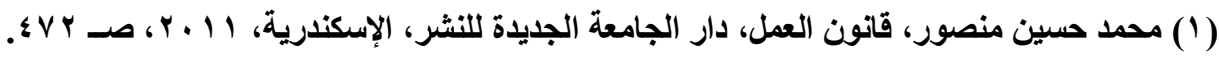

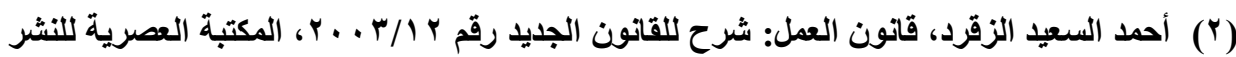

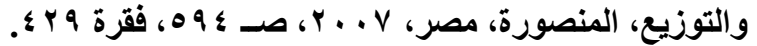

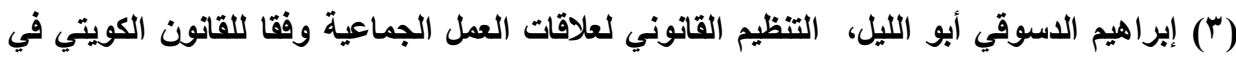

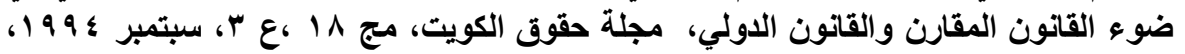

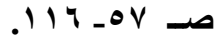

(؛) أحمد حسن البرعي، قانون العمل و قضية التنمية الاقتصادية في مصر: دراسة تحليلية للقانون

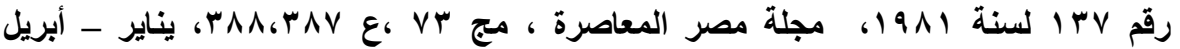

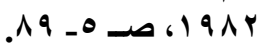

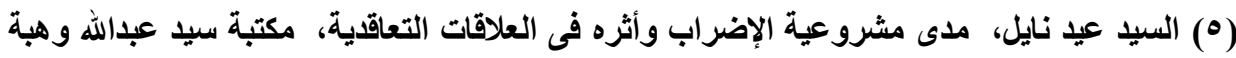

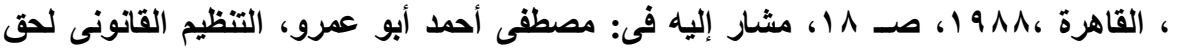
الإضراب فى القانون المصرى والفرنسي والتشريعات العربية، دار الكتب القانونية، مصر، التهرئ 
ويرى رأي أخير أن الإضراب هو (حق يخول للعمـال الامتــاع عن العمل الملزم

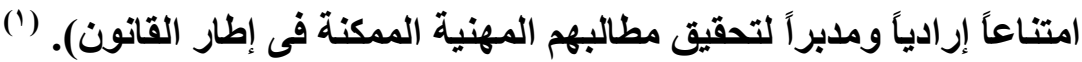

وأميل لهـذا التعريـف لأنسه عرَّف الإضـراب بأنـهـه حق يـتم ممارسـته فـى إطـار

القـانون، وبالتـالى فمن الممكن أن يسأل العامـل عن تعويض الأضــرار المترتبـة عن ممارسة هذا الحق، سواء أكاتت هذه الأضرار ناتجة عن مجاوزة حدود الحق التى نص عليها القانون أو كاتت ناتجة عن التعسف فى ممارسة هذا الحق.

كما أن هذا التعريف قد وضح بأن المطالب المبتغى تحقيقها من الإضراب يجب أن تكون مطالب من الممكن تحقيقها، مما قد يضفى صفة التعسف على الإضراب الذى بلى يتم بغرض تحقيق مطالب غير ممكنة أو صعبة التحقق. أما بالنسبة للقضاء المصري، فقد ورد تعريف للإضراب فى الحكم الصادر من محكمة أمن الدولـة العليـا طوارئ، حيث عرَّف الإضراب بأنـه (هو الامتــاع الجمـاعى

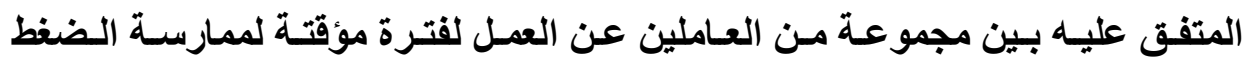
(ن) (لاستجابة لمطالبهم).

(1) مصطفى أحمد أبو عمرو، التنظيم القانونى لحق الإضراب فى القانون المصرى والفرنسي

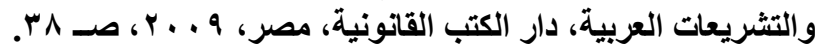

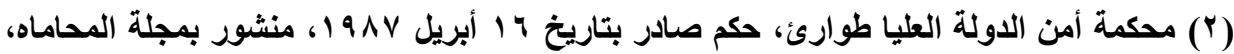

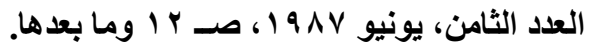




\section{المبمث الثاني \\ عناصر الإضراب}

هنايك عدة عناصر يجب أن تتوفر حتى يمكن القول أن ماقام به العمال من امتناع عن العمل يعد إضراباً، هذه العناصر هى التوقف عن العمل، و أن يكون هذا التوقف جماعيّا، وأن تكون هناك مطالب للعمال المتوقفين عن العمل، وسوف نتناول كل عنصر من هذه العناصر فى مطلب مستقل.

\section{المطاب الأول \\ التوقف عن العمل}

يعد التوقف عن العمل هو العنصر الجوهرى للإضراب عن العمل، والتوقف عن العمل يكون بعدم تتفيذ العمال للعمل الملتزمين به وفقاً لعقد العـل الفردى أو الجمـاعى أو وفقاً لقانون العمل. (1) ويجب أن يكون التوقف عن العمل بدون رضـاء صـاحب العمل، فامتــاع العمـال عن العمل باتفاق بينهم وبين صاحب العمل لإصلاح الآلات أو صياتتها، أو لإعادة ترميم

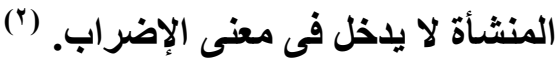




$$
\begin{aligned}
& \text { ويجب أن يكون الإضراب توقفاً صريحاً كاملاً عن العدل ولو لمدة محدودة، } \\
& \text { أما مجرد محاولة تقليل الإنتاجية أو تقليل جودة المنتج، أو تقديم الخدمة بشكل بطيء، } \\
& \text { فلا يعد ممارسة مشروعة للإضر اب وفقاً لقضاء محكمة النقض الفرنسية. (') } \\
& \text { ولا توجد مدة محدة للتوقف عن العمل حتى يوصف هذا التوقف بأنها إضراب، } \\
& \text { فالتوقف لمدة ساعة مثل التوقف عن العمل لعدة أيام. (广) } \\
& \text { ولا يشترط أن يبقى العمال المضربون فى مكان العل، فمن حقهم أن يذهبوا إلى } \\
& \text { بيوتهم أو إلى أى مكان آخر طالما اختاروا أن يتوقفوا عن العمل. (") } \\
& \text { ومن ناحية أخري فإن محكمة النقض الفرنسية قد أقرت بمشروعية الإضراب } \\
& \text { المتتابع، أي أن الإضراب لا يكون في كل مكان العمل في آن واحد، وإنمـا يحدد وقت الت }
\end{aligned}
$$

(1) Cass. Soc, 25 janvier 2011, $\mathbf{N}^{\circ}$ de pourvoi: 09-69030, Bull. civ. $\mathrm{V}, \mathrm{n}^{\circ} 28$, Et disponible sur: www.legifrance.gouv.fr

- Cass. Soc, 2 février 2006, Bull. civ. V, $n^{\circ}$ 52, p. 46 . Et disponible sur: www.legifrance.gouv.fr

- Cass. Soc, 10 octobre 1962, Bull. Civ, $n^{\circ}$ 702. Et disponible sur: www.legifrance.gouv.fr

- Cass. Soc, 25 février 1998, $N^{\circ}$ de pourvoi: 95-45457, Non publié au bulletin, disponible sur: www.legifrance.gouv.fr

- Cass. Soc, 16 juillet 1964, Bull.Civ.IV, $n^{\circ}$ 620, p 508, et disponible sur: www.legifrance.gouv.fr.

(2) Paul DURAND, La Grève et le lock-out en droit français, Op.cit.

(3) Maxence VERVOORT, L'exercice du droit de grève dans le secteur privé, Thèse Pour obtenir le grade de Docteur en Droit, Faculté de droit et de science politique, Université de nice sophia-antipolis, 2015, P iv. 


$$
\text { معين لكل قسم من أقسام العمل ليقوم بالإضراب بحيث ينتهى الإضراب في قسم ليبدأ في }
$$

وأقرت محكمـة النقض الفرنسية بمشروعية الإضـراب المتقطع، حيث يقوم

العمال بالإضراب عدة مرات فى ذات اليوم أو ذات الأسبوع. (r)

\author{
الإطلب الثانى \\ جماعية التوقف عن العمل \\ إن الإضراب هو حق فردى لكل عامل، فيحق للعامل ممارسـة هذا الحق أو عدم \\ ممارسته، إلا إنه عندما يقرر ممارسة هذا الحق، فيجب أن يمارسه فى جماعة ولا يحق \\ له أن يمارسه منفرداً، فالإضراب هو حق فردى يُمـارس بصورة جماعية. \\ فالإضراب هو عمل جمـاعي ولا يجوز أن يكون عمـلاَ فرديّا، فلا يجوز أن يتم

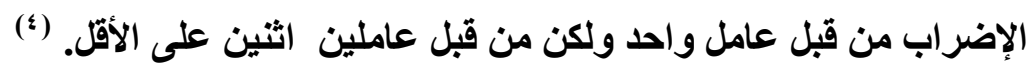

(1) Cass. Soc, 14 janvier 1960, Bull. IV, $N^{\circ} 43$, p. 36. Et disponible sur: www.legifrance.gouv.fr

(2) Cass. Soc, 25 janvier 2011, $\mathrm{N}^{\circ}$ de pourvoi: 09-69030, Bull. civ. $\mathrm{V}, \mathrm{n}^{\circ} \mathbf{2 8}$, Et disponible sur: www.legifrance.gouv.fr

(3) Maxence VERVOORT, Op.cit, P 26.

(4) Roger LATOURNERIE, Le droit français de la grève: étude théorique et pratique,Paris, Ed Sirey, 1972, P 173.

- Mathilde CARON, Grève dans le privé : conséquences pour les salariés, Les Cahiers Lamy, La revue des comités d'entreprise , ${ }^{\circ}{ }^{121}$, 25/12/2012. 
فالإضراب هو حق فردي يمـارس بصورة جماعية؛ لأنها بهذه الصورة يواجها

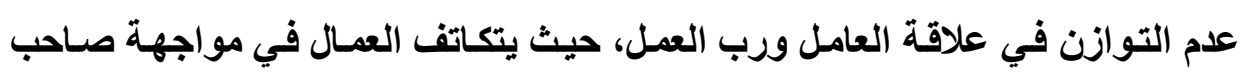

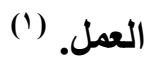

ولذلك اعتبرت محكمة النقض الفرنسية أن توقف أحد العمـال عن العمل ليس

باضضراب، وإنما هو انقطاع عن العمل، فلا يجوز للعامل ممارسة الإضراب منفرداً. (ץ) فالعامـل لا يستطيع أن يقوم بالإضـراب منفرداً، فـإن كـان لايـه مطالب مهنيـة، فيجب أن يقتع بعض العمال الآخرين للانضمام معه حتى يعتبر التوقف عن العمل الذى يقوم به إضراب.

ولكن يجوز للعامل منفرداً أن يشترك في إضراب عام على مستوى الدولة، بـأن

كان الإضراب يخص العاملين في مجال معين وهو الوحيذ الذي يعمل في هذا المجال في هذه الشركه، فرغم أنسه الوحيد المتوقف عن العمل لـدى رب العمل، إلا إن هذا يعد

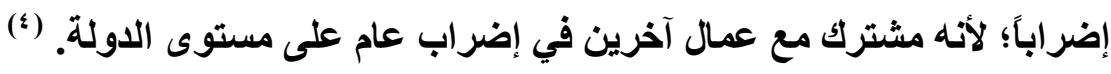

(1) Jacques Le GOFF, Droit du travail et société: Les relations collectives du travail, PUR, 2002, P 393.

- Céline LAURICHESSE, La grève en droit international privé, Op.cit, $P$ $36, n^{\circ} 19$.

(2) Cass.Soc, 17 décembre 1987, $N^{\circ}$ de pourvoi: 84-44339, Non publié au bulletin, disponible sur: www.legifrance.gouv.fr.

- Cass.Soc, 29 mars 1995, $N^{\circ}$ de pourvoi: 93-41863, Bull.civ, $1995 \mathrm{~V}$, $\mathrm{N}^{\circ}$ 111, p. 79, disponible sur: www.legifrance.gouv.fr.

(3) Céline LAURICHESSE, Op.cit, P 36, n 19.

(4) Cass.Soc, 13 novembre 1996, $\mathrm{N}^{\circ}$ de pourvoi: 93-42247, Bull civ. 1996, V, $N^{\circ} 379$, p. 272. disponible sur: www.legifrance.gouv.fr.

$=$ 
ولكن لا يشترط لوصف الامتنـاع عن العمل بأنها إضراب أن ينضم إليهه معظم

العمال، فانضمام مجموعة قليلة للتوقف عن العمل لا يمنع من وصفه بالإضراب. (1) ويالنسبة لقانون العمل المصري، فإنـه قد نص صراحة على أن التوقف عن العمل يجب أن يكون جماعياً، وأن الإضراب يكون إعلانـه وتنظيمـه من خلال النقابـات

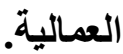

فوفقـا للمـادة ب 9 ا مسن قـانون العمـل المـصري فـإن إعـلان وتنظيم الإضـراب يكون من خلال النقابـــات العماليــهـ دفاعا عن مصالــــح العــــال المهنية والاقتصادية (r) (الاجتماعية.

وكذلك نصت المادة ؛ 1 من قانون النقابـات العمالية ("ّ) نصت على اختصاص النقابة العامة بالموافقة على تنظيم الإضراب للعمـال طبقا للضوابط التى ينص عليها

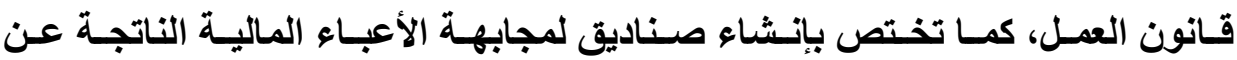

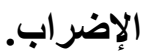

- Cass.Soc, 29 mars 1995, $\mathrm{N}^{\circ}$ de pourvoi: 93-41863, Bull.civ, $1995 \mathrm{~V}$, $\mathrm{N}^{\circ}$ 111, p. 79, disponible sur: www.legifrance.gouv.fr.

(1) Cass.Soc, 3 octobre 1963, Bull. civ. IV, p. 534, $n^{\circ}$ 645. disponible sur: www.legifrance.gouv.fr.

- Cass.Soc, 21 juin 1967, Bull. Civ, $n^{\circ} 498$. disponible sur: www.legifrance.gouv.fr.

(r) النقابة العمالية هى منظمة تتكون بطريقة حرة من جماعة من العمال على وجه دائم ومنظم لتمثيل

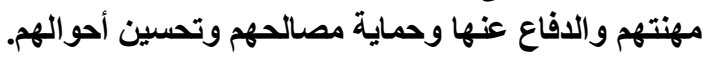

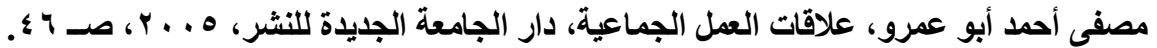

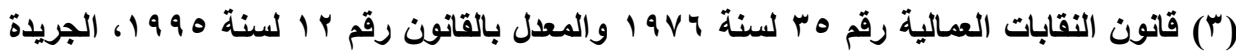

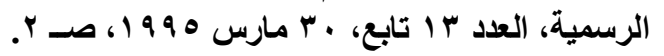

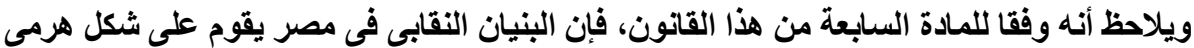

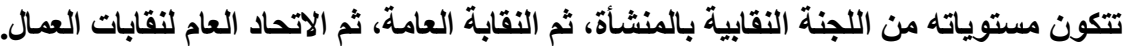


وبالتـالي، فالقـانون المصري يختلف في ذلك عن القـانون الفرنسي، فالقـانون الفرنسي لم يشترط الدعوة للإضراب من قبل النقابة العمالية بالنسبة لعمـال القطاع الخاص، واكتفى فقط بشرط أن يكون التوقف عن العمل جماعياً، أمـا القانون المصرى فقد اشترط أن تتم الدعوة إلى الإضراب وتتظيمه من قبل النقابة العمالية. فوفقا لقانون العمل المصري، فإن الإضراب لا يكون مشروعاً إلا إذا دعت إليه النقابة العمالية، أما قيام مجموعة من العمال بالتوقف عن العمل بدون دعوة من النقابة

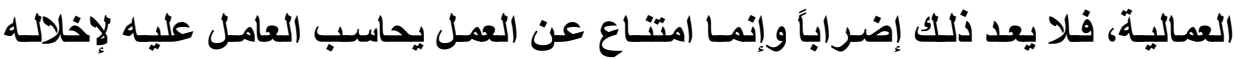

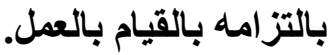

بل إن قيام العامل بالإضراب عن العمل دون دعوة من النقابـة العمالية يعد خطاً جسيماً يجيز فصل العامل وفق نص المادة 9/9/9، حيث إن هذه المادة اعتبرت أن عدم مراعاة ضوابط ممارسة الحق فى الإضراب الواردة فى المواد ب 9 أـ ـ 9 اليعتبر خطأ

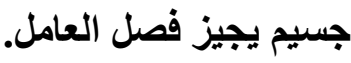
ومسلك المشرع المصرى فى اشتراط أن تتم الدعوة للإضر اب وتتظيمه من قبل النقابة العمالية، يجد تبريره فى أن النقابة العمالية يكون لها إمكانيات تسمح لها بتنظيم

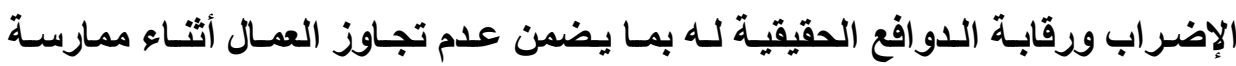
الإضراب أو خروجهم على الضوابط التى نص عليها القانون. أمسا القـانون الفرنسي فلم يشترط دعوة النقابـة للإضـراب أو تنظيمـه بالنسبة للعمال العاملين فى القطاع الخاص، واشترط ذلك فقط بالنسبة للعمال العاملين بـالمرافق العامـة، فهؤلاء العمـال لا يجوز لهم التوقف عن العمل بدون دعوة من قبل نقابـاتهم

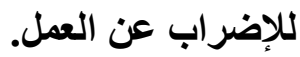




\section{المطالب الثالث}

\section{وجود هطالب للعمال المتوقفين عن العمل}

يجب أن تكون هناك مطالب مهنية محددة للعمال المضربين عن العمل، فلا يجوز

التوقف عن العمل بدون وجود هذه المطالب المتعلقة بالعمل والمطلوبـة من صساحب

العمل، فبدون وجود هذه المطالب لا يعد التوقف عن العمل إضراباً. (')

فتوقف العمـال عن العمـل توقفـا جماعيـا دون أن يكـون هنـاك مطالب يريدون

تحقيقها لا يعد إضرابا، وإنما إخلال بتثفيذ التزام العامل فى قيامه بالعمل.

وقد أكد قانون العمل المصرى على هذا العنصر فى المـادة ب 9 ا منـه، حيث

أكـدت علــى أن حـق الإضــراب الـسلمى للعمـال يكـون دفاعا عن مصالحهم المهنية

والاقتصادية والاجتماعية، فالهـف مـن الإضراب هـو تحقيق هذه المـصالح أو الدفاع

هذا الثرط بضرورة وجود مطالب للعمـال المضربين عن العمل يثير نقطتين، أحدها هو مضمون هذه المطالب والنقطة الأخرى هو مدى جواز الإضراب التضامنى، و سوف نتناول هاتين النقطتين فى فرعين مستقلين.

(1) Cass. Soc, 22 octobre 2014, $\mathrm{N}^{\circ}$ de pourvoi: 13-19858 13-19859 13-19860, Bull.civ V, $\mathbf{n}^{\circ}$ 246. Et disponible sur: www.legifrance.gouv.fr

- Cass. Soc, 28 février 2007, N de pourvoi: 06-40944, Bull.civ V, ํo 33. Et disponible sur: www.legifrance.gouv.fr

- Cass. Soc, 8 avril 1974, $N^{\circ}$ de pourvoi: 73-40450, Bull.civ V, $N^{\circ} 223, P$. 211. Et disponible sur: www.legifrance.gouv.fr 


\section{الفرع الأول \\ هضمون المطالب}

يمكن القول أن المطالب التي تبرر الإضراب يجب أن تكون لها شروط معينة، فليست كل المطالب يمكن أن تبرر الإضراب.

فيجب أن تكون المطالب مهنية، أي متعلقة بالعمل، فـالحق في الإضراب مقرر للاففاع عن المصالح المهنية للعمال، كما أن المطالب المهنية هي المطالب التي يستطيع صاحب العمل الاستجابة لها، أمـا المطالب غير المهنيـة فلا يستطيع صـاحب العمل أن يلبيها لأنها غير متعلقة بالعمل. (1) كما أن هذه المطالب يجب أن تكون مطالب مشروعة أي غير مخالفة للقانون، والمطالب المهنية هي مطالب تتعلق بشروط العمل وظروفه. (r) وهذه المطالب المهنية قد تكون طلب تنفيذ صساحب العمل لالتزاماته كتحسين ظروف العمل، أو الوفاء بمقابـل سـاعات العمل الإضـافية، أو المطالبة بتنظيم انتخابـات نقابية داخل مكان العمل، وكذلك تعد المطالبة بتوفير وسيلة مواصلات أو المطالبة بمنح

بدلات سفر مطالب مهنية.

(1) Jennifer PARASSOL, Le droit de grève, Art disponible sur: www.blogdegerardpicovschi.com, la date de mise en ligne est: 9 novembre 2006.

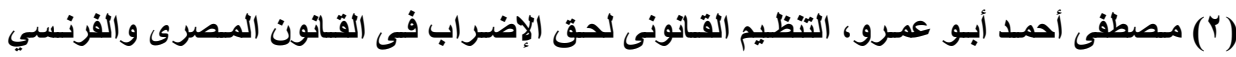

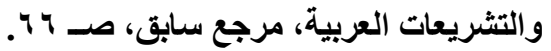

(3) Céline LAURICHESSE, Op.cit, P 38, nº 20. 
وكذلك إضر اب العمال لمطالبة رب العمل بالسماح لهم بممارسـة دورهم النقابى

يعد إضراباً مشروعاً؛ لأن المطالبة بممارسة الدور النقابى هي مطالبة مهنية. (1) وتعتبر مطالب مهنية أية مطالب متعلقة بالأجور مثل طلب زيادتها، أو رفع الحد

الأدنى لها، أو طلب دفع أجر مقابل العمل الإضافى. (؟)

وكذلك تعتبر مطالب مهنية المطالب المتعلقة بظروف العمل مثل تغيير ظروف

العمل، كتحديد وقت بلاية العمل ونهايته أو تحديد وقت الراحة. (َ)

وقد نصت المادة ب 19 من قانون العمل المصري على تحديد مضمون مطالب

العمال بأنها المطالب المهنية والاقتصادية والاجتماعية، أب أن يطالب العمـال بمطالب مهنية أو اقتصادية او اجتماعية، ونرى أن هذه العبارة عبارة واسعه مطاطه، وكـان يكفى المشرع أن يذكر عبارة (المطالب المهنية)؛، لأن المطالب الاقتصادية والاجتماعية قد تكون مطالب غير متعلقة بالعمل ولا يستطيع صاحب العمل أن يلبيها. فقد تقوم النقابة بالدعوة لإضراب لمطالبة الدولة بمطالب اقتصادية أو اجتماعية مما يخرج عن قدرة رب العمل فى تلبيتها، ومما قد يؤدى إلى صبغ الإضراب بالصبغة السياسية، وهو ما يعد مرفوضا فى مكان العمل.

(1) Cass. Soc, 30 mars 1999, $N^{\circ}$ de pourvoi: 97-41104, Bull.civ, $V$, $N^{\circ} 140$, p. 101. Et disponible sur: www.legifrance.gouv.fr.

(2) Cass. Soc, 17 juillet 1996, $\mathrm{N}^{\circ}$ de pourvoi: 94-42964, Et disponible sur: www.legifrance.gouv.fr

(3) Cass. Soc, 26 février 1981, $N^{\circ}$ de pourvoi: 79-41359 79-41376, Bull.Soc, $N^{\circ} 161$, Et disponible sur: www.legifrance.gouv.fr 
لذا نرى أن المشرع المصرى يجب أن يقصر المطالب المبررة للإضراب على المطالب المهنية فقط، وأن ينص المشرع صراحة على حظر الإضراب لدوافع سياسية

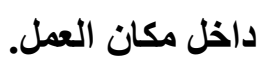

فقد اسـتقرت محكمـة النقض الفرنسية منــ زمسن بعيد على عدم مشروعية الإضراب داخل مكان العمل للمطالبة بمطالب سياسية، وأسست المحكمـة قضاءها على لهـي أن الاستور أعطى للعمال الحق في الإضراب للافاع عن مصالحهم المهنية، فمشروعية الإضراب تتوفر عندما يتم في هذا الإطار للافاع عن هذه المصالح المهنية، أمـا عندما

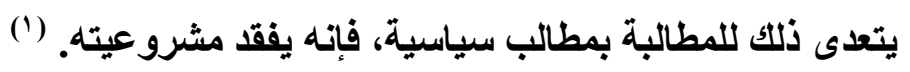

(1) Cass. Soc, 30 janvier 2008, $\mathrm{N}^{\circ}$ de pourvoi: 06-21781, Non publié au bulletin, disponible sur: www.legifrance.gouv.fr.

- Cass. Soc, 23 mars 1953, $N^{\circ}$ de pourvoi: 53-01398, Bull.soc, $N^{\circ} 253, P$. 188, et disponible sur: www.legifrance.gouv.fr.

- Cass. Soc, 14 janvier 1982, $N^{\circ}$ de pourvoi: 79-42669, Bull.soc, $n^{\circ} \quad 16$, et disponible sur: www.legifrance.gouv.fr.

- Cass. Crim, 23 octobre 1969, $N^{\circ}$ de pourvoi: 68-91860, Bull. Crim, ${ }^{\circ}$ 267, et disponible sur: www.legifrance.gouv.fr.

- Cass. Soc, 10 mars 1961, Bull.soc $N^{\circ}$ 333, et disponible sur: www.legifrance.gouv.fr.

- Cass. Soc, 1 mars 1961, Bull.soc, $N^{\circ}$ 270, et disponible sur: www.legifrance.gouv.fr.

- Cass. Soc, 29 janvier 1960, Bull.soc, $N^{\circ}$ 113, et disponible sur: www.legifrance.gouv.fr.

- Cass. Soc, 5 octobre 1960, Bull.soc, $\mathrm{N}^{\circ}$ 818, et disponible sur: www.legifrance.gouv.fr. 
فالتوقف عن العمل لمجرد عقـاب صـاحب العمل على قرار أصدره دون وجود

$$
\text { مطالبات محددة يعد إضر اباً غير مشروع. (') }
$$

ويجب أن يلاحظ أن الإضراب هو وسيلة للضغط على رب العمل لتلبية المطالب

المهنية وليس وسيلة لتحقيق هذه المطالب مباشرة، فلا يجوز للعمال ممارسة الحق في الإضر اب لتحقيق مطالبهم، فمثلاً إذا كاتت مطالبة العمال هي عدم العمل سـاعات زائدة فلا يحق للعمـال ممارسـة الإضراب يوميـا في هذه السـاعات الزائدة؛؛ لأن بـذلك يكون

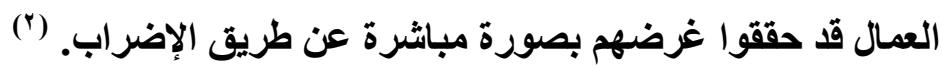

فالحق في الإضراب لا يعطي للعمال الحق في تغيير ظروف العمل وفقاً لرغبتهم،

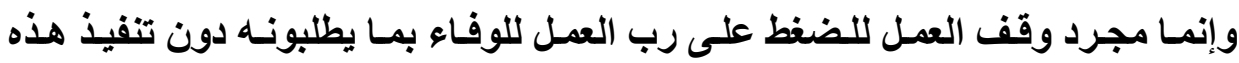
المطالب من خلال الإضراب. (') ومن ناحية أخرى فقد رفضت محكمة النقض الفرنسية إضفاء صفة الإضراب على وقف العمل احتجاجاً على فصل أحد العمال بسبب خطأ شخصي يوجب الفصل؛ لأن قرار صاحب العمل قرار مشروع. (؛)

(1) Cass. Soc, 10 décembre 1986, $\mathrm{N}^{\circ}$ de pourvoi: 83-41502, Bull.civ $\mathrm{V}$, $\mathrm{N}^{\circ}$ 585, p. 444. Et disponible sur: www.legifrance.gouv.fr

(2) Cass. Soc, 21 juin 1989, $\mathrm{N}^{\circ}$ de pourvoi: 88-44240, Bull.civ V, $\mathrm{N}^{\circ} 457$, $\mathrm{p}$. 278. et disponible sur: www.legifrance.gouv.fr

- Cass. Soc, 7 juin 1995, $\mathrm{N}^{\circ}$ de pourvoi: 93-43895, Bull.civ V, $\mathrm{N}^{\circ} 179$, p. 131. et disponible sur: www.legifrance.gouv.fr.

(3) Cass. Soc, 7 novembre 1984, $\mathrm{N}^{\circ}$ de pourvoi: 82-41441, Bull.civ V, $\mathrm{N}^{\circ}$ 418. et disponible sur: www.legifrance.gouv.fr

(4) Cass. Soc, 16 novembre 1993, $\mathrm{N}^{\circ}$ de pourvoi: 91-41024, Bull.civ V, $\mathrm{N}^{\circ}$ 268 P. 183. et disponible sur: $\underline{\text { ww.legifrance.gouv.fr }}$ 
فالحق في الإضراب لا يجوز أن يكون أداة في يد العمال لتعطيل السلطة التأديبية

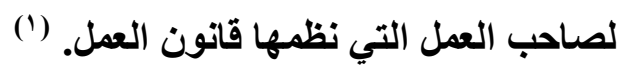

وكنلك فقد نصت المـادة به 19 من قانون العمل المصرى على حظر الإضراب بقصد تعديل اتفاقيـة العمل الجماعيـة أثناء مدة سريانها، فيجب احترام اتفاقيّة العمل الجماعية طالما ماز الت سارية ولا يجوز الإضر اب عن العمل للضغط على صاحب العمل لهل

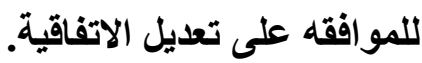

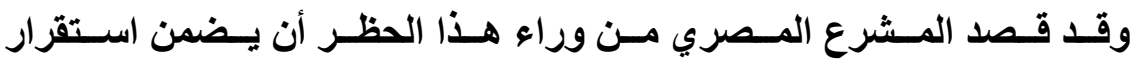

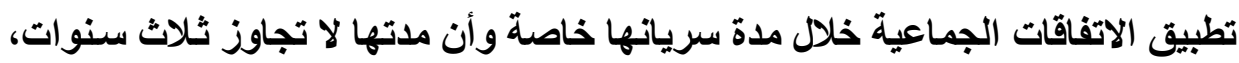

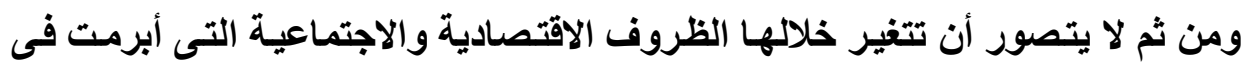

ظשها. (ץ)

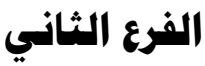

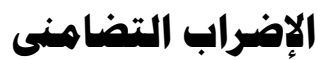

يثور التساؤل عن مدى مشروعية الإضراب التضامنى؛ وهو إضراب العمال في

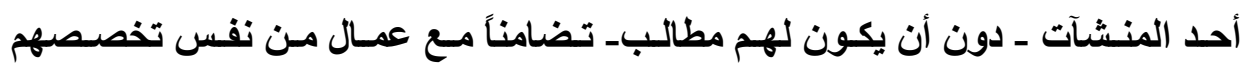

$$
\text { مضربين في منشأة أخرى لصاحب عمل آخر. }
$$

(1) Jean DEPREZ, Grève de solidarité et pouvoir sanctionnateur du chef d'entreprise: vers un assouplissement des conditions de licéité de la grève de solidarité?, Rev Droit social, №2, P 143-152, février 1988.

(ץ) مصطفى أحمد أبو عمرو، التنظيم القانونى لحق الإضراب فى القانون المصرى والفرنسي

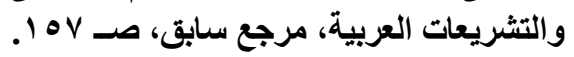

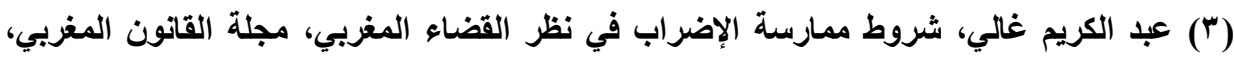

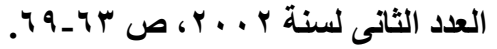


فقد حكم القضاء الفرنسي بعدم مشروعية هذا الإضراب؛ وذلك لأن رب العمل لن يستطيع تلبية مطالب العمال المضربين لأن المطالبات متعلقة بعمال آخرين يعملون للى بلى

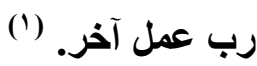

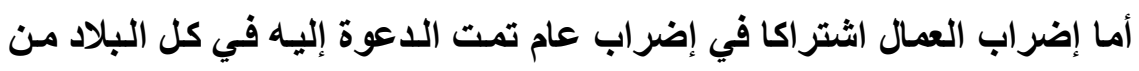
قبل العاملين في نفس المجال، فهذا إضراب مشروع بـالرغم من عدم وجود مطالبات إمبراب

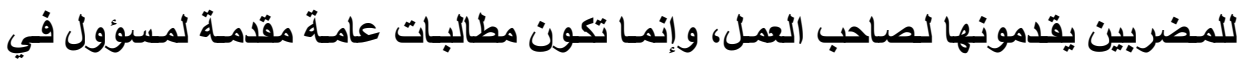

وكذلك يجوز إضراب العمال تضامناً مـع أحد العمـال داخل نفس المنشأة، وذلك

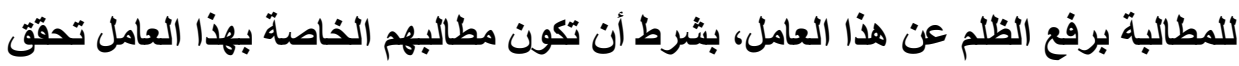

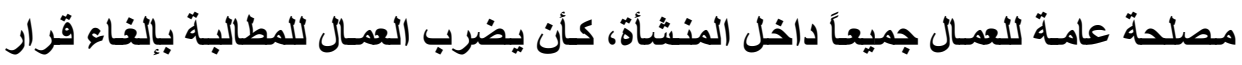

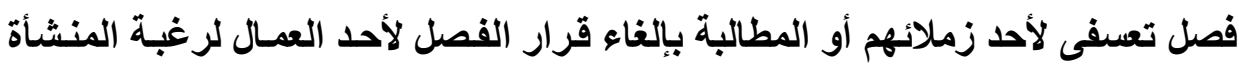
فى تقليل حجم العمالة.

(1) Cass. Soc, 4 mai 1966, $N^{\circ}$ de pourvoi: 82-41441, Bull.civ V, $N^{\circ} 411$, p 347. et disponible sur: $\underline{w w}$.legifrance.gouv.fr

(2) Cass. Soc, 30 mars 1971, $N^{\circ}$ de pourvoi: 69-40333, Bull.civ V, $N^{\circ} 265 \mathrm{P}$. 221. et disponible sur: www.legifrance.gouv.fr

(3) Cass. Soc, 2 juillet 2014, $\mathrm{N}^{\circ}$ de pourvoi: 13-12562, Bull.civ, $\mathrm{V}, \mathrm{n}^{\circ} 158$, et disponible sur: www.legifrance.gouv.fr

- Cass. Soc, 27 novembre 1985, $\mathrm{N}^{\circ}$ de pourvoi: 82-43649, Bull.civ IV, $\mathrm{n}^{\circ}$ 559, p. 405. et disponible sur: www.legifrance.gouv.fr

- Cass. Soc, 22 novembre 1995, $N^{\circ}$ de pourvoi: 93-44017, Bull.civ V, $\mathrm{N}^{\circ}$ 307, p 220. et disponible sur: www.legifrance.gouv.fr

- Cass. Soc, 17 décembre 2003, $\mathrm{N}^{\circ}$ de pourvoi: 01-46251, Bull.civ $\mathrm{V}, \mathrm{N}^{\circ}$ 317, p. 319. et disponible sur: www.legifrance.gouv.fr

- Cass. Soc, 5 janvier 2011, $N^{\circ}$ de pourvoi: 10-10685, Bull.civ V, $N^{\circ} 1$. et disponible sur: www.legifrance.gouv.fr 


\section{المبحث الثالث}

\section{ضوابط همارسة الإضراب}

ذكرنا سابقًا أن حق الإضراب له عدة ضوابط يجب أن تتو افر حتى يعد الإضراب

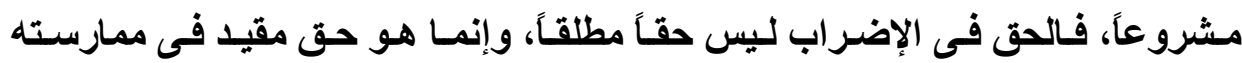
بمجموعه من الثروط والضوابط التى تضمن عدم التجاوز فى ممارسته.

فالإضــراب هـو حـق اجتمــاعى معتـرف بــه دسـتورياً، إلا إن ممارســة هـــا

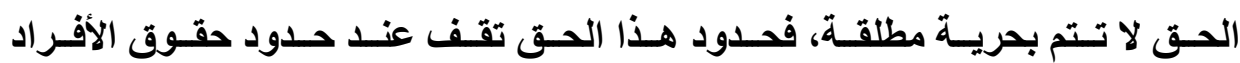

الآخرين. (1)

فضوابط ممارسة الحق فى الإضراب تم النص عليها صراحة فى قانون العمل

المـصري، فهذا القـانون قــ نظم ممارسـة الحق فـى الإضـراب بوضـع مجموعـة مـن الرن الشروط والإجراءات لممارسة هذا الحق.

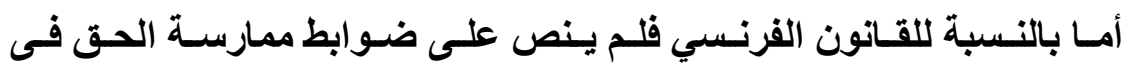
الإضراب فى القطاع الخـاص، حيث أقرت هذه الضوابط محكمة النقض الفرنسية فى في

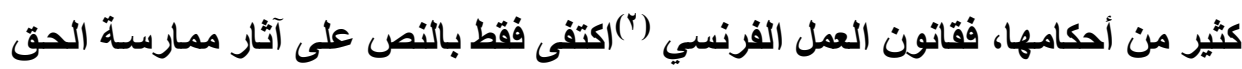
في الإضراب.

(1) عبد الكريم غالي، مرجع سابق.

(2) Code du travail, Version consolidée au 1 février 2017. disponible sur: www.legifrance.gouv.fr 
وحتى نقوم بتناول ضوابط ممارسة الإضراب، فسوف نقوم بتقسيم هذا

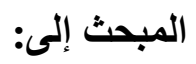

المطلب الأول: حظر الإضراب أثناء الوساطة أو التحكيم.

$$
\text { المطلب الثاني: الإخطار. }
$$

المطلب الثالث: حظر الإضراب في المنشآت الاستراتيجية.

\section{الإطلب الأول}

\section{هظر الإضراب أثناء الوساطة أو التمكيم}

ممــا لا شـك فيـه أن الإضـراب عن العـل لـه آثثار سلبية على العامـل وصـاحب

العمل، فأيام الإضراب تحتسب إجازة بدون أجر بالنسبة للعامل، ويترتب على الإضراب توقف منشأة صاحب العمل مما يسبب خسائر اقتصادية له.

ولذلكك يكون مسن مصلحة العامـل ورب العـل محاولـة حل النزاع وديـاً باتبـاع الوسائل السلمية لحل منازعـات العمل وعدم لجوء العمـال للإضراب إلا كحل أخير فى حالة تعنت رب العمل وعدم إجابته لمطالب العمال. فوفقاً للمادة ب 19 من قانون العمل، فإنه يحظر على العمـال الإضراب أو إعلاتهـه بواسطة منظماتهم النقابية خلال جميع مراحل وإجراءات الوساطة والتحكيم، فالإضراب الأي يمارس خلال مراحل وإجراعات الوساطة والتحكيم يعد إضراباً غير مشروع.

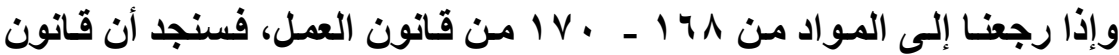
العمل قد أوجب على العامل وصاحب العمل الاخول فى مفاوضة جماعية فى حالة وجود 
نزاع بينهم، فإذا لم تتم تسوية النزاع خلال ثلاثين يوم من بدء المفاوضات جاز للطرفين أو أيهما التقدم بطلب للجهة الإدارية المختصة لاتخاذ إجراءات الوساطة. ووفقا للمادة و ل ا ، فإنه إذا لم يقبل الطرفـان أو أحدهما التوصيات التى قدمها الوسـيط، كـان لأي منهمـا أن يتقدم للجهـة الإداريـة المختصة بطلب لاتخـاذ إجراءات التحكيم.

ويرى رأي فى الفقه أن قانون العمل المصرى قد ألزم العمـال بـاللجوء للوسـائل السلمية لحل النزاع القـائم مـع رب العمـل قبل لجـوئهم للإضـراب عن العمل وإلا كـان الإضراب غير مشروع، ويُعد خطاً جسيماً من جـانبهم، وأنسه لا يجوز للعمـال الإضراب عن العمل قبل التفاوض مـع صـاحب العمل، ولا يجوز لهم الإضراب أثناء الوسـاطة أو (1) التحكيم. (1) ونـرى أن المشرع قــ نص صـراحة على حظر الإضـراب خـلال جميع مراحل و إجراءات الوساطة والتحكيم وفقا لصريح نص المسادة ب 9 أ، ولكن المشرع لم يحظر على العمـال الإضـراب أثنـاء التفـاوض مـع صـاحب العـل، فـإذا كـان العــال ملتزمين بالتفاوض مـ صـاحب العمل فى حالة وجود نزاع إلا إنهم ليس من المحظور عليهم الإضر اب أثناء التفاوض؛ لأن الحق فى الإضراب من الحقوق الدستورية التى لا يجوز حظرها أو تقييدها إلا بنص صريح.

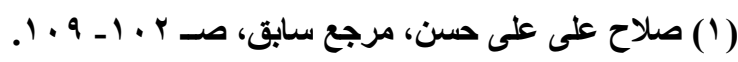

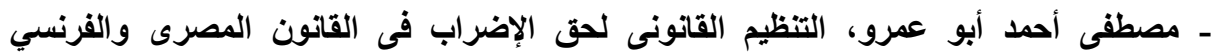
و التثريعات العربية، مرجع سابق، صـ بـ ـ أئ. 
وليس معنى حظر الإضراب خلال مراحل الوسـاطة والتحكيم حظره أيضاً أثنـاء

المفاوضات؛ وذلك لأن الطرفان قد لا يلجـأوا للوسـاطة أو التحكيم، فالنصوص السابقة صريحة فى أن اللجوء للوساطة أو التحكيم جوازى وليس ملزماً. وبالتالى فنرى أن لجوء العمال للإضر اب أثثاء المفاوضات بنـاء على دعوة من النقابة لا يُعد خطاً جسيماً يبرر فصلهم.

\section{الإطباب الثانى}

\section{الإخطار}

الإخطار هو إجراء سابق على الإضراب يكشف عن الرغبة فيه والإصرار عليه،

$$
\text { ويقصد منه إخبار رب العمل بأن العمال تنتوي القيام بإضراب. }
$$

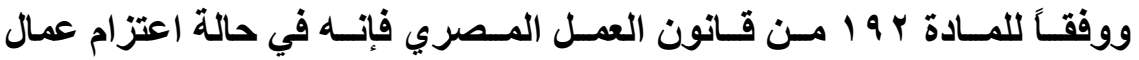

المنشأة ذات اللجنة النقابية الإضراب في الأحوال التى يجيزها هذا القانون، يجب على اللجنة النقابية إخطار كلٍ من صاحب العمل والجهة الإدارية المختصة قبل التاريخ المحدد للإضراب بعشرة أيام على الأقل، وذلك بكتاب مسجل بعلم الوصول. فإذا لم يكن بالمنشأة لجنة نقابية، فيقع على عـاتق النقابـة العامـة المعنيةــ بعد موافقـة مجلس إدارتهـا بالأغلبيـةـــالإخطار باعتزام العمال الإضراب عـن العمـل، وفي جميع الأحوال يتعين أن يتضمن الإخطار الأسباب الدافعة للإضراب، والمدة الزمنية المحدده له.

وهذا الضابط مهم جداً لأنـه يقضى على مـا يطلق عليه (الإضراب المفـاجئ)، بحيث لا يُفاجأ رب العمل بالإضراب، وإنما يكون مستعداً له بحيث يقرر مـا سـوف يفعله 
أيام الإضر اب لتخفيف آثاره، فضلا عن إمكانية التوصل لحل ودى للنزاع خلال فترة العشرة أيام، وقد يمتثل رب العمل لمطالب العمال خلال تلك الفترة. ووفقا لنص المادة ب 9 ا، فإن الالتزام بالإخطار يقع على عـاتق اللجنة النقابية، وذلكك إذا كانـت هنـاك لجنـة نقابيـة بالمنشـأة، أمـا إذا لـم تكن هنـاك لجنـة نقابيـة، فبان الإخطار يقع على عاتق النقابة العامة، وهذا الحكم يتلاءم مـع الحكم المقرر فى قانون العمل بأن الدعوة للإضراب وتنظيمه تكون على عاتق النقابة العمالية، فمن المنطقى أن تلتزم هى بالإخطار. وتلتزم اللجنة النقابية أو النقابة العامة بإخطار رب العمل ومكتب القوى العاملة الأى يقع فى دائرته المنشأة التى ينتوى العمـال الإضراب بها، وقد حدد القانون مدة للإخطار بحيث يكون قبل الإضراب بعشرة أيام على الأقل. وقد ألزم القانون النقابة أن توضح فى الإخطار الأسباب الدافعة إلى الإضراب، وترجيع العلـة فـى ذلك إلى أن المشرع قد قدر بـأن صـاحب العمل عندما يعلـم مسبقاً

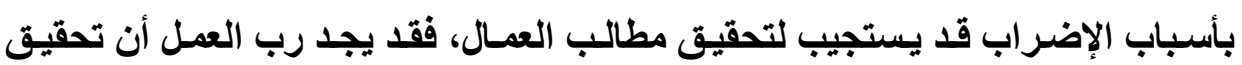
مطالب العمال أمر أقل تكلفه من الخسائر التى قد تترتب على الإضراب، كمـا أن إخطـار

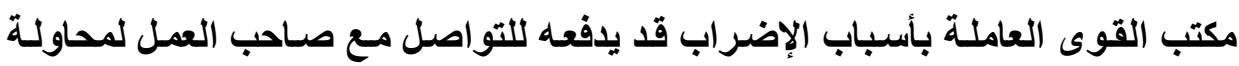
إقناعه بتلبية مطالب العمال. (1) كما يجب أن يشتمل الإخطار على المدة المحددة للإضراب، وقد تطنَب القانون ذلك حتى يكون صـاحب العمل على علـم بالمـدة التى سيستغرقها الإضـراب فيوفق 


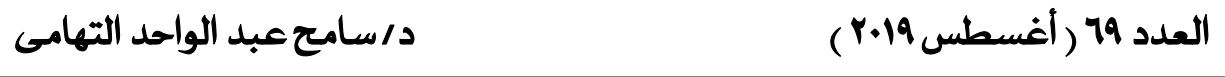

$$
\begin{aligned}
& \text { أوضاعه فيما يكون قد التزم به فى تعاقداته المستقبليه مع عملائه، فيقلل بقدر الإمكان } \\
& \text { من الخسائر الاقتصادية المترتبة على الإضراب. (') } \\
& \text { والإخطار يجب أن يكون كتابياً وأن يتم في شكل خطاب مسجل بعلم الوصول، } \\
& \text { وذلك حتى لا يثار أي نزاع حول القيـام بالإخطـار من عدمـه، فالخطـاب المسجل بعلم } \\
& \text { الوصول يثبت حدوث الإخطار بسهولة. } \\
& \text { ولـم يـص قـانون العـلـل الفرنسـي على شـرط الإخطـار للإضـراب فـى القطـاع }
\end{aligned}
$$

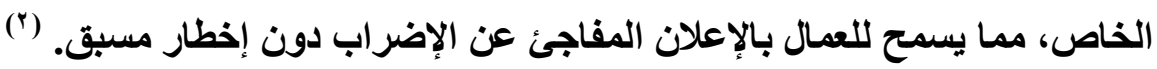

$$
\begin{aligned}
& \text { فكل ماتطلبه القضاء الفرنسي أن يتم إخبار رب العمل بمطالب العمال عند البدء } \\
& \text { فى الإضراب، ولم يحدد القضاء وسيلة معينة لإخبار رب العمل بهذه المطالب. (") }
\end{aligned}
$$$$
\text { (1) (1) المرجع سابق، نفس الصفحة. }
$$

(2) Mathilde CARON, Grève dans le privé, Op.cit.

- Francisco Mananga, L'exercice du droit de grève et du droit de retrait par les personnels du secteur social et médico-social : une question d'équité, Journal du droit des jeunes, 2009/9, n $^{\circ}$ 289, p. 33-39.

(3) Cass. Soc, 30 juin 2015, $\mathrm{N}^{\circ}$ de pourvoi: 14-11077, disponible sur: www.legifrance.gouv.fr.

- Cass. Soc, 28 février 2007, $\mathbf{N}^{\circ}$ de pourvoi: 06-40944, Bull. civ, V, $\mathbf{N}^{\circ} 33$. Et disponible sur: www.legifrance.gouv.fr

- Cass. Soc, 7 juin 1995, $N^{\circ}$ de pourvoi: 93-46448, Bull.civ $V$, $N^{\circ} 180$, p. 132. Et disponible sur: www.legifrance.gouv.fr

- Cass. Soc, 24 mars 1988, $N^{\circ}$ de pourvoi: 85-43604, Non publié au bulletin. disponible sur: www.legifrance.gouv.fr

- Cass. Soc, 19 novembre 1996, $N^{\circ}$ de pourvoi: 94-42631 94-42635, Bull.civ $\mathrm{V}, \mathrm{N}^{\circ}$ 391, p. 280. et disponible sur: www.legifrance.gouv.fr 
فيحق للعمـال البــء في الإضـراب فور إبـلاغ رب العمل بمطالبـاتهم دون حاجـة

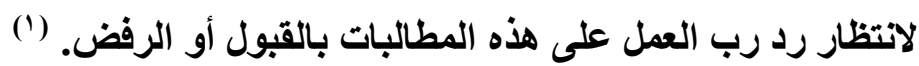

\section{الاملب الثالث \\ هظر الإضراب فى المنشآت الاستراتيمية}

نصت المادة ؟ 9 ا من قانون العمل المصرى على (يحظر الإضراب أو الدعوة

إليسه فـي المنشآت الاستراتيجية التـي يترتب على توقف العدل فيها الإخسلال بـالأمن

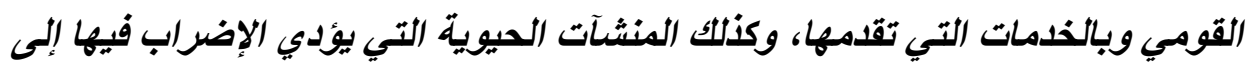

إضطراب في الحيـاة اليوميسة لجمهور المسواطنين. ويصدر قرار مسن رئسيس مجلس

الوزراء بتحديا هذه المنشآت).

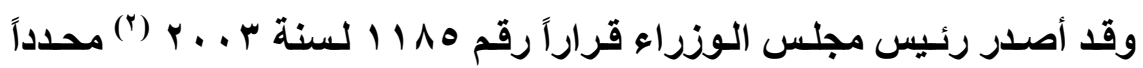

المنشآت الاستراتيجية والحيويـة التى يحظر فيها الإضراب، حيث حدد هذه المنشآت

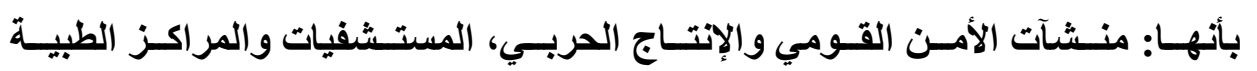

والصيدليات، المخـابز، وسـائل النقل الجمـاعي للركـاب، وسـائل نقل البضائع، منشآت

(1) Cass. Soc, 22 octobre 2014, $\mathrm{N}^{\circ}$ de pourvoi: 13-19858 13-19859 13-19860,

Bull.civ V, $\mathbf{n}^{\circ}$ 246. Et disponible sur: www.legifrance.gouv.fr

- Cass. Soc, 11 juillet 1989, $\mathbf{N}^{\circ}$ de pourvoi: 87-40727, Bull.civ V, $\mathbf{N}^{\circ}$ 509, p. 308. et disponible sur: www.legifrance.gouv.fr

- Cass. Soc, 7 février 1990, $N^{\circ}$ de pourvoi: 87-43566 87-44473 87-44488,

Bull.civ V, $N^{\circ} 42$, p. 27. et disponible sur: www.legifrance.gouv.fr

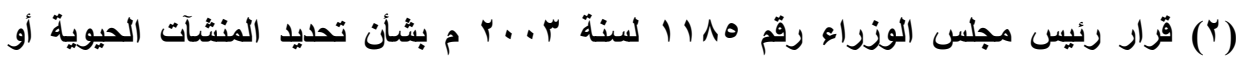

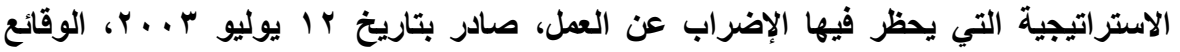

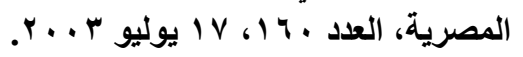


الـدفاع المـدني، منششآت ميـاه الـشرب والكهربـاء والغــاز و الصرف الصحي، منشـآت الاتصالات، منشآت المواني والمنائر والمطار ات، والمؤسسات التعليمية.

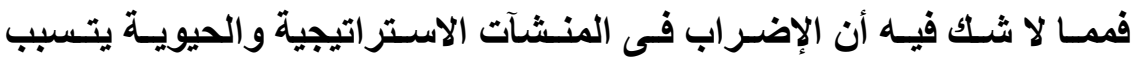
بمشاكل كبيرة لصاحب العمل ولمشاكل أكثر لعملاء هذه المنشأت وقد يتسبب فى شـلل الحياة اليومية للأفراد، مثل الإضراب فى شركات الاتصالات أو شركات النقل الجماعى، بل وقد يؤدى الإضراب لتعريض حياة المواطنين للخطر مثل الإضراب فى المستشفيات والصيدليات الخاصة.

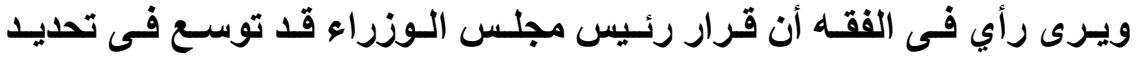
المنشآت الاستراتيجية والحيويـة التى يحظر على العـاملين الإضـراب فيها، وأن هذا القرار يؤدى إلى تضييق ممارسة الحق فى الإضراب. (') ونـرى مـن جانبنــا أن قـرار رئسيس مجلـس الـوزراء لــم يتوسـع فـى تعديـــ

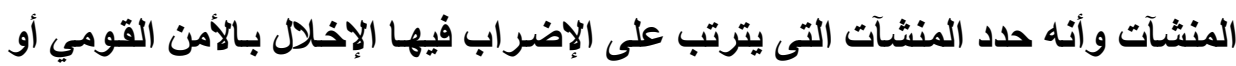
إضطراب في العياة اليومية لجمهور المواطنين مثلمـا نصت المـادة ؛ 9 ، فـالقرار قد أعمل حكم المادة؛ لأن كل المنشآت الواردة فيه تمس الأمن القومى أو الحياة اليومية للمـواطنين ويترتب على الإضـراب فيهـا مخـاطر شــيدة للأمسن القـومى أو لمـصالح

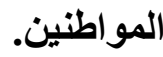




\section{الفصل الثاني}

المسؤولية المدنية للنقابة العمالية

عن همارسة الإضراب

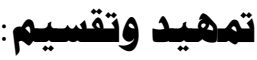

وفقـا للمسادة ب 19 مـن قـانون العـل المـصري فللعــال حق الإضراب السلمى

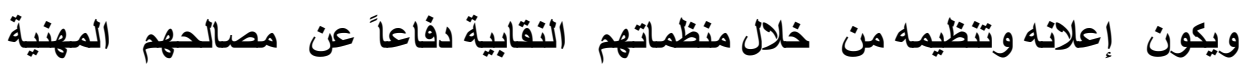

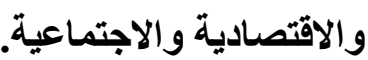

وبالتالي يظهر من هذا النص أن المشرع المصري قد أعطى النقابة العمالية

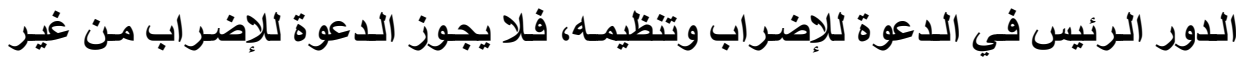

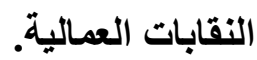

أمسا بالنسبة للقـانون الفرنسي، فِإن النقابـة تلعب الدور الـرئيس فى الدعوة للإضراب وتنظيمه بالنسبة للعاملين فى المرافق العامة فقط دون العاملين فى القطاع

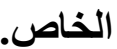

ويرجع ذلك إلى أن النقابة العمالية هي مؤسسة تهدف للافاع عن المصالح

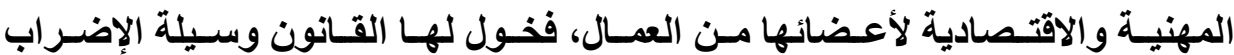

لاستخذ(مها عند الحاجة للافاع عن هذه المصالح. (1)

(1) Adrien LANCIAUX, La responsabilité delictuelle du syndicat à l'occasion d'un conflit collectif, Art disponible sur: www.legavox.fr, La date de mise en ligne est: 28/9/2012. 
ويثور التساؤل عن مدى إمكانيـة الرجوع على النقابـة العمالية بـالتعويض عن الأضرار التى قد تترتب عن الإضراب الذى دعت إليه فى حالة ارتكاب أي خطأ من جاتب النقابة أو فى حالة التعفف من جانبها فى استعمال حقها فى اللاعوة للإضراب وتنظيمه.

حتى نجيب عن هذا التساؤل، فسوف نبحث فى مدى جواز إقامـة المسؤولية

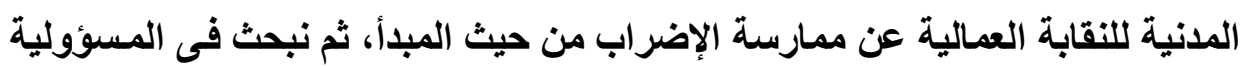
المدنيـة للنقابـة عـن الأخطـاء المرتكبـة فـى الــــوة إلـى الإضــراب أو تنظيمـه، ثـم

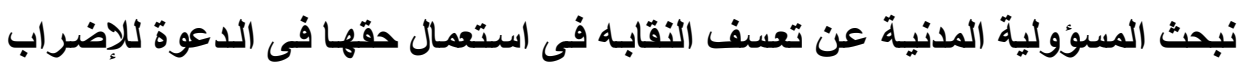
وتنظيمه. وبالتالى فسوف نقوم بتقسيم هذا الفصل إلى: المبحث الأول: مبدأ المسؤولية المدنية للنقابة العمالية عن ممارسة الإضراب. المبحث الثاني: المسؤولية المدنية عن ممارسة النقابة الخاطئة للإضراب. المبحث الثالث:المسؤولية المدنية عن ممارسة النقابة التعفية للإضراب. 


\section{المبحث الأول}

هبدأ المسؤولية المدنية للنقابة العمالية عن همارسة الإضراب

مبدأ المسؤولية المدنية للنقابـات العماليـة من الموضوعات التي شـهـت جدالاً

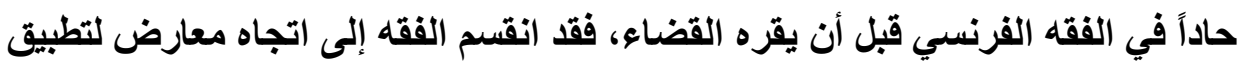

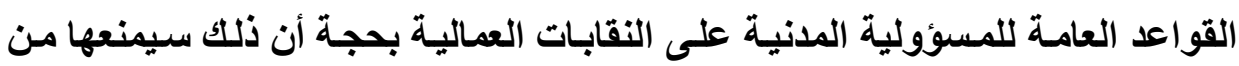

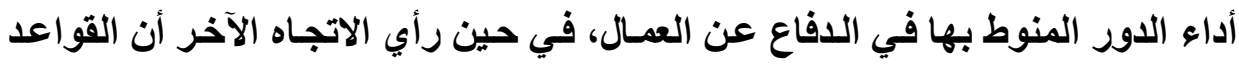
العامة في المسؤولية المدنية يجب أن تطبق على أي فعل يعد خطأ حتى ولو ارتكبته المئه

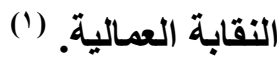

ولكن تم حسم الأمر من قبل المجلس الدستورى حيث رفض إقرار مبدأ (عدم المسؤولية المدنية) للنقابـات العمالية بصفة عامـة وعن وعن ممارسـة الحق في الإضراب

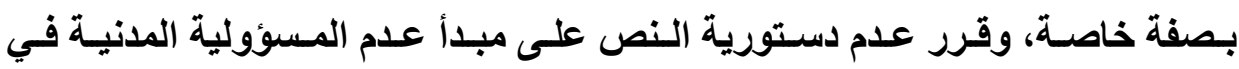

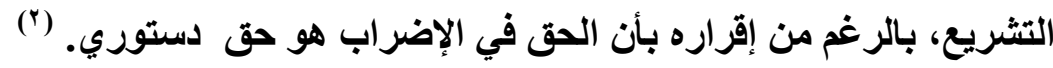
وجاءت محكمة النقض الفرنسية بعد قرار المجلس الاستورى الفرنسي بعدة

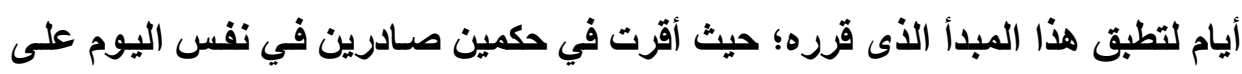

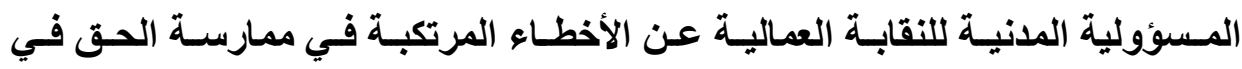
الإضراب والمسؤولية عن التعسف في ممارسة هذا الحق. (")

(1) Birame DIOUF, Op.cit, P 297-302.

(2) CC, décision $n^{\circ}$ 82- 144, 22 Octobre 1982, RCC, p. 61, et disponible sur : http://www.conseil-constitutionnel.fr/conseil-con..decision-n-82-144-dcdu-22-octobre-1982.8004.html.

(3) Cass. Soc, 9 novembre 1982, $N^{\circ}$ de pourvoi: 80-13958 80-14046 8014097, Bull.soc, $N^{\circ}$ 614, Et disponible sur: www.legifrance.gouv.fr. $=$ 
فهذان الحكمان الصادران من الغرفة الاجتماعية لمحكمة النقض الفرنسية قد وضعا المبدأ الذى أقره المجلس الاستورى موضع التطبيق بـالحكم بتأييد المسؤولية

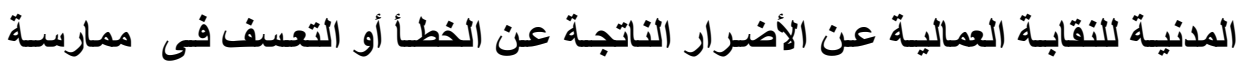

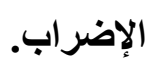

وبالتالي فالقواعد العامـة للمسؤولية المدنية تقبل التطبيق على الأخطاء التي ترتكبها النقابة العمالية أثناء ممارسة دورها في الاعوة للإضراب أو في تنظيمه. ويجب ملاحظة أن القواعد العامـة في المسؤولية المدنية التقصيرية هي التي تنطبق على الأخطاء المرتكبة من قبل النقابة العمالية أثناء ممارسة الحق في في الإضراب؛

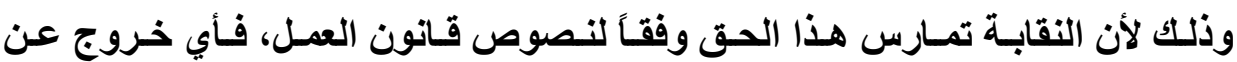
الضوابط المقررة في قانون العمل والخاصـة بممارسـة الحق في الإضر اب يمثل خطاً تقصيريّاً، ممـا يثير المسؤولية التقصيرية للتقابـة في حالة توافر أركـان المسؤولية

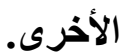

وكذلك الأمر فيما يتعلق بالتعسف في ممارسة الدق في الإضراب، فتنظيم النقابة

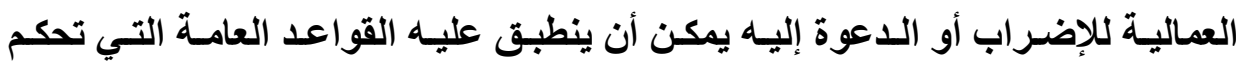

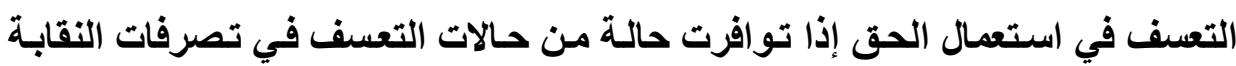
العمالية أثناء الدعوة للإضر اب أو تنظيمه.

فالنقابة العمالية تتمتع بالثخصية القانونية الاعتباريـة، ممـا يؤدى إلى إمكانية

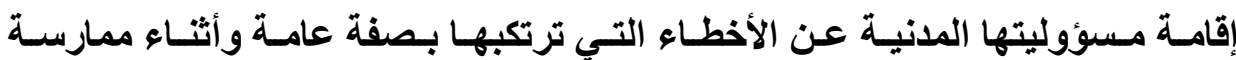

الإضر اب بصفة خاصة. (1)

- Cass. Soc, 9 novembre 1982, $\mathrm{N}^{\circ}$ de pourvoi: 80-16929, Bull.soc, $\mathrm{N}^{\circ} 615$, Et disponible sur: www.legifrance.gouv.fr.

(1) Adrien LANCIAUX, Op.cit. 


\section{المبحث الثاني \\ المسؤولية المدنية عن همارسة النقابة الخاطئة للإضراب}

انتهينا إلى أن القواعد العامة في المسؤولية المدنية التقصيرية ستقبل التطبيق

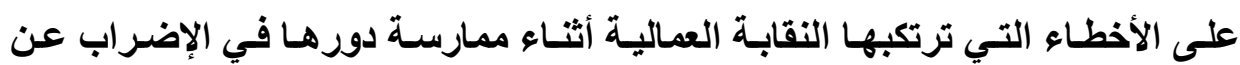

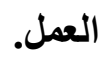

فالنقابة العمالية تلعب دوراً محورياً في ممارسة الحق في الإضراب؛ حيث أنـاط بها القـانون الإعلان عن الإضـراب ثم تتظيمـه بعد ذلك، فدور النقابـة لا يقتصر عن الإنس الإعلان فقط ولكن يستمر لتتظيم الإضراب.

وتطبيقـا للقواعد العامـة في القـانون المـدني، فحتى ثثثور المسؤولية المدنيـة التقصيرية للنقابة العمالية، فيجب توافر الأركان الثلاث للمسؤولية المدنية التقصيرية وهى الخطأ والضرر وعلاقة السببية، فيجب أن ترتكب النقابـة خطاً تقصيريّا يترتب عليه ضرر بالمدعى.

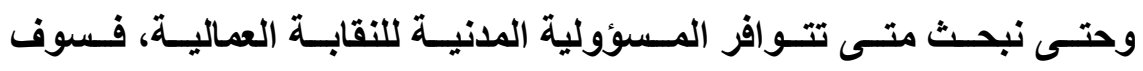
نبحث كل ركن من هذه الأركان، ثم نبحث الأثر المترتب على توافر هذه الأركان في حق النقابة. وبالتالي سنقوم بتقسيم هذا المبحث إلى: المطلب الأول: أركان المسؤولية. المطلب الثاني: أثر المسؤولية. 


\section{المطاب الأول}

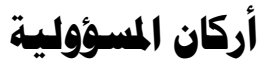

وفقـا للقواعد العامـة، فبإن أركـان المسوؤلية التقصيرية هي الخطأ والضرر

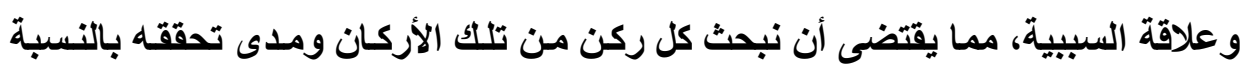

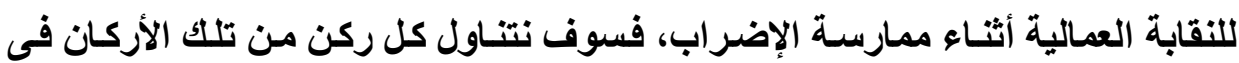
فرع مستقل.

\section{الفرع الأول}

\section{الذطأ}

الخطأ فى المسئولية التقصيرية هو إخلال بالتزام قانوني بـأن يصطنع الثخص

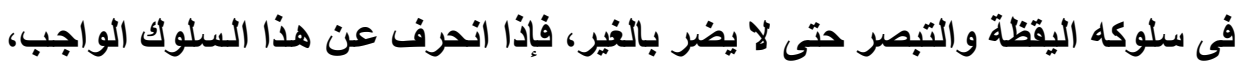
وكان من القدرة على التمييز بحيث يدرك أنسه قد انحرف، كـان هذا الانحراف خطأ

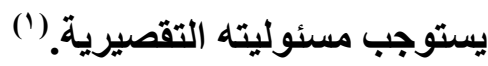
والمبدأ المستقر عليه هو جواز إقامة المسؤولية المدنية للشخص المغنوي عن

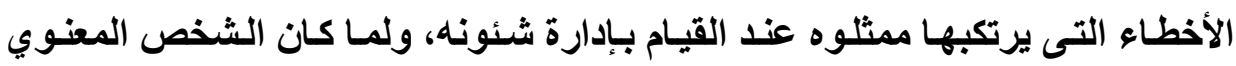

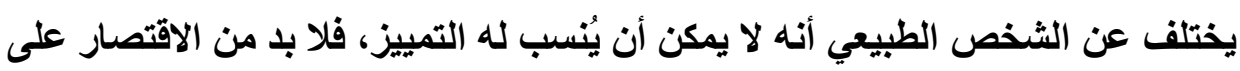

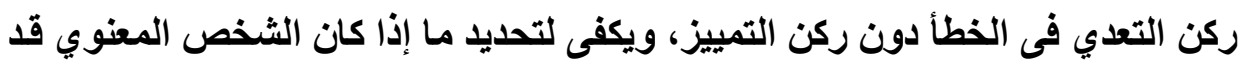

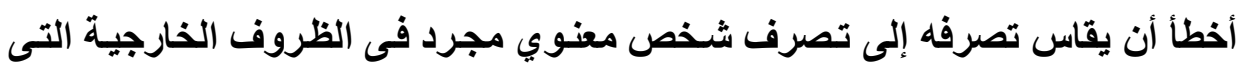


تصرف فيها، فـإذا انحـرف عـن هـذا المقيساس المـادي، كـان هنـاك خطسأ، وتحققت (1) مسئوليته.

وتطبيقا لذلك، فعندما أقرت محكمة النقض الفرنسية المسؤولية المدنيـة للنقابـة العمالية عن ممارسة الحق في الإضرابـ في الحكم السابق الإشـارة إليهـ فقد حددت المحكمة في الحكم الحالات التي يمكن مساعلة النقابة مدنياً عنها، وهى عندما ترتكب الرهب

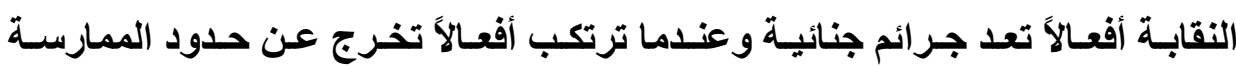
الطبيعية للحق في الإضراب. (ن) وبالتالي فإن أي فعل يمثل جريمة جنائية ترتكبه النقابة أثناء ممارسـة الإضراب يعد خطأ تقصيري، وكذلك يُعد خطأ أي فعل لا يمكن اعتبـاره ممارسـة طبيعيـة للحق في الإضراب، أي يخرج عن حدود الممارسة الطبيعية للحق في الإضراب.

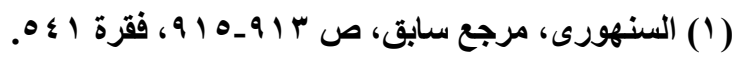

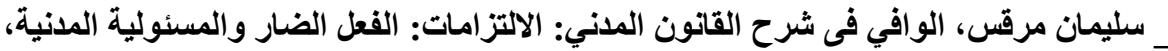

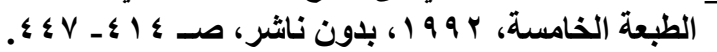

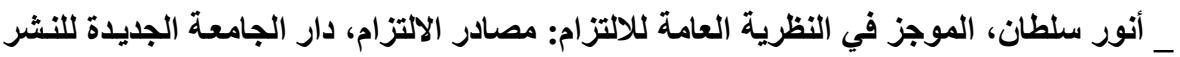

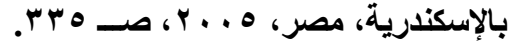

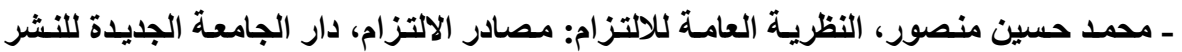

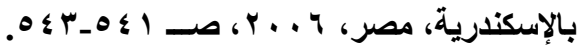

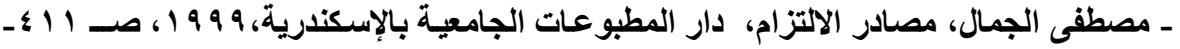
.

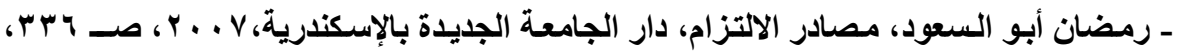
.rTV

(2) Cass. Soc, 9 novembre 1982, $N^{\circ}$ de pourvoi: 80-13958 80-14046 8014097, Bull.soc, $N^{\circ} 614$, Et disponible sur: www.legifrance.gouv.fr. 
أولاً الممارسة غير الطبيعية للإضراب:-

كيف يمكن أن ثُعد الدعوة إلى الإضراب أو تنظيمه ممارسـة غير طبيعية للحق

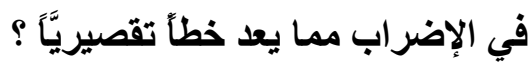

يمكن القول إن النقابة تُعد مرتكبة لخطأ تقصيري عندما تخالف القواعد التي

$$
\text { نص عليها القانون والتي تنظم ممارسة الإضراب. }
$$

وكذلك فالدعوة لإضراب غير مشروع - لمخالفته للقانون - يُعد خطاً تقصيريًّاً من جانب النقابة للخروج عن الممارسـة الطبيعية للإضراب، فالدعوة من قبل النقابة لعمل إضراب لتحقيق مطالب سياسية يعد خطأ؛ لأن هذا الإضر اب يعتبر إضراباً سياسيًاً

غير مشروع. (1)

كمـا أن الـعوة لإضـراب غير سـلمى مـن جانب النقابـة هو خطأ تقصيري؛

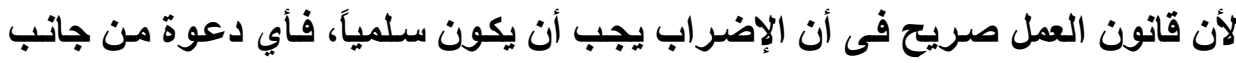

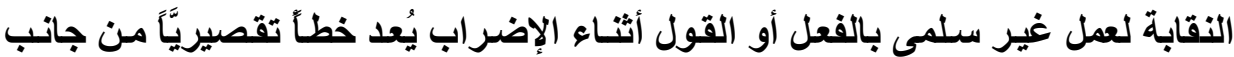

كما أنه وفقاً للمـادة بو 19 من قـانون العمل المصري، يجب على النقابة إخطار كل من صاحب العمل ومديرية القوى العاملة التى يقع فى دائرتها المنشأة التى سيتم

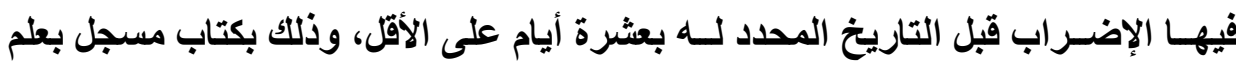

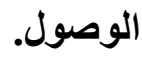

(1) Maxence VERVOORT, Op.cit, $P$ I r . 
فباذذا لـم تقـم النقابـة باخطـار رب العمـل ومديريـة القوى العاملـة قبـل الإضـراب

بعشرة أيام على الأقل، فتكون قد ارتكبت خطاً تقصيريَّاً لمخالفتها نصّاً من النصوص المنظمة لممارسة الحق في الإضراب.

وكـللك الأمسر فـان دعـوة النقابـة للإضـراب فـى إحـدى المنشـآت الحيويـة أو

الاستراتيجية التى حظر القانون الإضر اب بها يُعد خطأ من جانب النقابـة لمخالفة ذلك لنص المادة ؛ 9 ألمن قانون العمل المصري.

وكذلك يُعد خطأ من جانب النقابـة اللدعوة للإضراب بقصد تعديل اتفاقية العمل الجماعية حال سريانها لمخالفة ذلك لنص المادة س 19 من قانون العمل المصري. وكذلك يَعد خطأ من جانب النقابة الدعوة للإضراب فى أي مرحلة من مراحل الوساطة أو التحكيم لمخالفة ذلك لنص المادة بـ 1 من قانون العمل المصري.

ومسن جانبهـا فقد اعتبرت محكمـة النقض الفرنسية أن دعوة النقابـة العمـال لتعطيل النظام المعلوماتى داخل المؤسسة هو نوع من أنواع الممارسـة غير الطبيعية للإضراب عن العمل مما يعتبر خطأ من جاتب النقابة. (') ثانيا- ارتكاب جريمة جنائية:تعتبر النقابة قد ارتكبت جريمـة عندما تحرض العمـال المضربين على ارتكاب جرائم أثناء الإضراب، فالتحريض على الجريمة يُعد في حد ذاته جريمة وفى ذات الوقت خطاً تقصيريّاً.

(1) Cass. Soc, 26 janvier 2000, $\mathrm{N}^{\circ}$ de pourvoi: 97-15291, Bull.civ, $\mathrm{V}, \mathrm{N}^{\circ} 38$, p. 28, Et disponible sur: www.legifrance.gouv.fr. 
فمن الجرائم الشائع ارتكابها في الإضراب جريمـة الاعتداء على حريـة العمل، حيث يقوم العمـال المضربون بمنـع العــال غير المضربين من العمل بـأي طريقة مـن

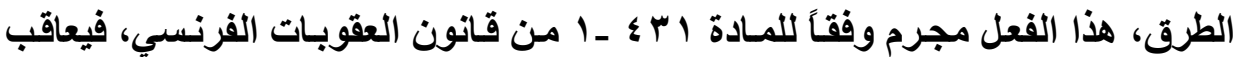
العامل المضرب بعقوبة السجن مدة لا تزيد عن عام وغرامة لا تزيل عن خمسة عشرة ألف يورو إذا اعتدى العامل المضرب على حرية العمل للعمال الآخرين.

ونفس الأمر في قانون العقوبات المصري الذي اعتبر الاعتداء على حرية العمل جريمـة وعاقب فاعلها بـالحبس مدة لا تجـاوز سنتين وغرامـة لا تزيــ عن مائة جنيـه وذللك في المادة ه ه منهـ.

وبالتالي فالنقابة تُعتبر قد ارتكبت خطاً تقصيريًَ إذا نظمت الإضراب وحرضت

العمال المضربين على القيام بمنع العمال غير المضربين من العمل. ( )

وكذلك ثُعد النقابـة قد ارتكبت خطاً إذا حرضت العمـال المضربين على احتلال

مكان العمل بالقوة لإجبار رب العمل على الامتثال لمطالبهم. (؟)

ومن الجرائم التي يمكن أن يرتكبها العمال المضربون احتجاز أفراد داخل مكسان

العمل ومنعهم من الخروج منه مثل احتجـاز عمـلاء المنشأة أو احتجـاز العمـال الآخرين غير المضربين، فهذا الاحتجاز للأشخاص يعد جريمه جنائية وفقا لنص المـادة ؛ Y Y I من قانون العقوبات الفرنسي، حيث يعاقب مرتكبها بالسجن مدة لا تزيد عن عشرين

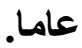

(1) Cass. Soc, 30 janvier 1991, $N^{\circ}$ de pourvoi: 89-17332, Bull.civ, $\mathrm{V}$, № 40, p. 25, Et disponible sur: www.legifrance.gouv.fr.

(2) Cass. Soc, 8 novembre 1984, $\mathrm{N}^{\circ}$ de pourvoi: 82-14816, Bull.civ, $\mathrm{V}, \mathrm{n}^{\circ}$ 423, Et disponible sur: www.legifrance.gouv.fr.

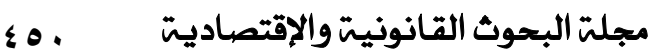


وبالتالي فالنقابة تُعتبر قد ارتكبت خطاً تقصيريَّاً عندما تنظم الإضراب وتحرض اضن العمال المضربين على القيام باحتجاز أفراد داخل مكان العمل.

وهناك كثير من الجرائم الأخرى التي من الممكن ارتكابها من قبل العمـال أثنـاء

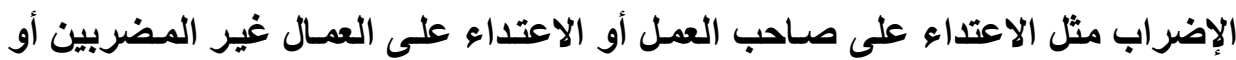
إتلاف أدوات العمل، فكل هذه الأفعال يمثل التحريض عليها من قبل النقابة العمالية خطاً تقصيريَّا ، فأي تحريض للعمال من جاتب النقابة للخروج عن سلمية الإضراب يُعد خطاً تقصيريَّاً.

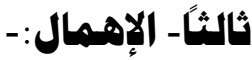

يُعد الإهمال أحد صور الخطأ التقصيري، حيث يخل الشخص بمـا يجب أن يقوم به، وحيث إن النقابة العمالية مسؤولة عن تنظيم الإضراب، فهل من المككن أن يُنسب إليها خطأ الإهمال في تنظيم هذا الإضراب؟ وحله

أجابت محكمة النقض الفرنسية بـالنفي على هذا التساؤل؛ حيث نقضت حكم محكمة استتناف(Angers) الذى أيد الحكم على النقابة بتعويض عن الأضرار التي

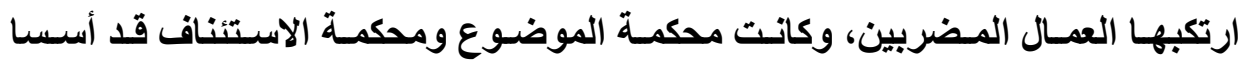
حكمهما على أساس وجود ممثل النقابة في الإضراب وعدم منعه العمـال المضربين من الاعثداء على العمال غير المضربين. فقد نقضت محكمة النقض هذا الحكم مقرة أن (النقابة لا تُسأل إلا عن الأخطاء التـي برتكبها الععـال المضريون، وتكون هـي قد حرضتهم عليها، أمسا الأخطساء التـي يرتكبها العمال ولا تكون قد حرضتهم عليها فلا تُسأل عن عدم منعها). (')

(1) Cass. Soc, 29 janvier 2003, $\mathrm{N}^{\circ}$ de pourvoi: 00-22290, Non publié au bulletin, disponible sur: www.legifrance.gouv.fr. 
وقد أكلدت محكمة النقض هذا الحكم في وقت لاحق مقررة أن النقابة لا تكون

مسؤولة عن متابعة العمال أثناء تنظيم الإضراب مما ينفى عنها المسؤولية المدنية إن

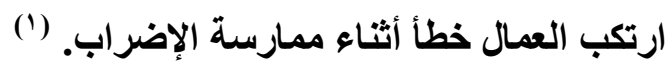

وقد انتقد رأي في الفقه هذا الحكم على أساس أن النقابة هي المنوط بها قانونـاً

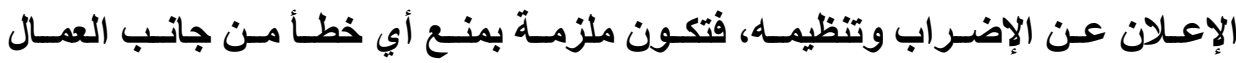

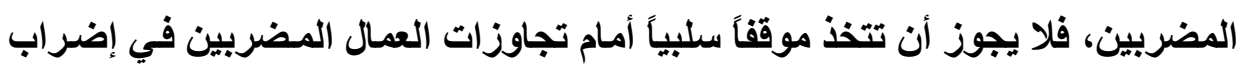

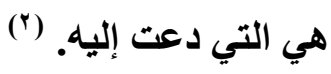

ونـرى أن إهمـال النقابـة أثنـاء تنظيم الإضـراب هو خطأ سلبي يمكن أن تكون

مسؤولة عن الأضرار المترتبة عليه، خاصـة أن قانون العمل المصري صريح في أن

$$
\text { النقابة مسؤولة عن تنظيم الإضراب. }
$$

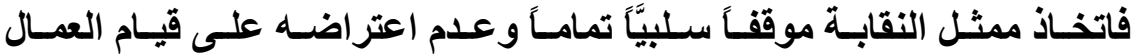

المضربين بالاعتداء على العمال غير المضربين هو إهمال؛ لأنه يجب أن يقوم بأي دور إيجابى في منـع ذلك، فصمته على ذلك يعد إقراراً منـه يشجع العمـال المضربين على التمادى في ذلك.

لـلك نـري أن الموقف السلبى للنقابـة أمسام الأخطـاء الجسيمة للعمـال أثــاء الإضراب هو خطأ تقصيري؛ لأن النقابة منوط بها قانونا تنظيم الإضراب، فسكوتها أمام الأخطاء الجسيمة للعمال هو تثجيع للعمال على القيام بهذا الخطأ.

(1) Cass. Civ, 26 octobre 2006, $\mathrm{N}^{\circ}$ de pourvoi: 04-11665, Bull.civ,II, $\mathrm{n}^{\circ}$ 299, p. 275, disponible sur: www.legifrance.gouv.fr.

(2) Adrien LANCIAUX, Op.cit. 


\section{"المسؤولية عن أخطاء العمال المضربين}

ومن ناحية أخرى، فالنقابة لا تكون مسؤولة عن أخطاء العمال المضربين إن هى قامـت باتخـاذ كل الإجراءات القانونيـة السليمة للاعوة للإضراب، وقامـت بتنظيم الإضر اب بصورة قانونية سليمة خالية من أي خطأ، وقامت بمنع العمـال المضربين من الأخطاء التي يحاولون ارتكابها أثنـاء الإضراب، فقيام العمـال بعد ذلكك بـأي خطأ أثنـاء

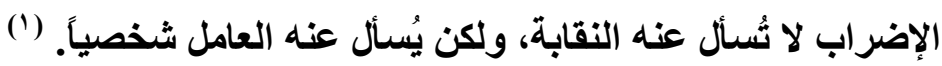
فالنقابة مسؤولة فقط عن الأخطاء التي ترتكبها أثناء الدعوة للإضراب وأثناء

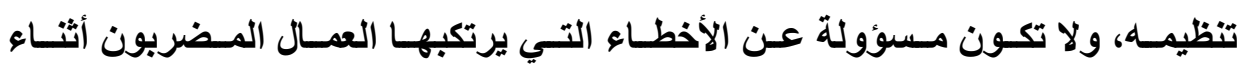
الإضراب، فكون العمال المضربين أعضاء في النقابة لايؤدى إلى توافر علاقة تبعية بين

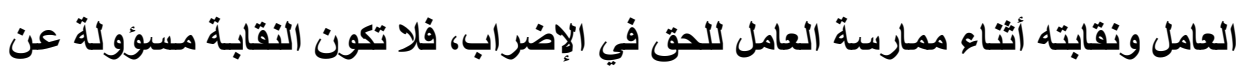

فمجرد انتــاء العامـل للنقابـة لا يكفى لتوافر علاقة التبعيـة بينـه وبين النقابـة التي تعد الثرط الرئيسي لإقامة مسؤولية المتبوع عن أفعال تابعه؛ لأن النقابة لا تملك

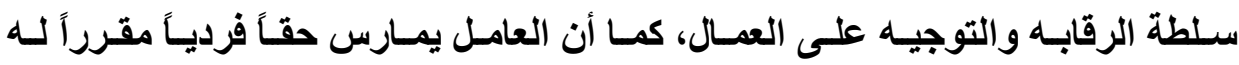
(广) دستوريَّاً

ولقد أكـدت محكمـة الـقضض الفرنسية أن النقابـة لا تكـون مسؤولة مـدنياً عن الأخطاء التي يرتكبها العمال المضربون أعضاء النقابة حتى ولو كانوا يحتلون مناصب

(1) Ibid.

(2) Maxence VERVOORT,Op.cit, $P$ I r . 
تنظيمية بالنقابة، طالما أن ما ارتكبوه من أخطاء لم تأمر به النقابة نفسها أثناء الإعلان عن الإضراب أو أثناء تنظيمه. (1) وقد أكدت محكمة النقض في حكم آخر على عدم مسؤولية النقابة عن الأخطاء التي يرتكبها العمال أثناء الإضراب معللة ذلك بـأن النقابـة لا تملكك سلطة على العمـال الأعضاء فيها، فهى فقط تدافع عن حقوقهم من خلال الدعوة الى الإضراب للدفاع عن مصالحهم، وتقوم بتظيم هذا الإضراب، إلا إنها لا تملك سيطرة تامة عليهم أثناء قيامهم

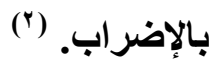

ويتضح من هذه الأحكـام أن محكمة النقض لا تريــ أن توسـع من المسؤولية

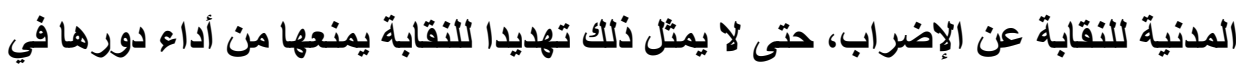
الافاع عن أعضائها من خلال وسيلة الإضراب عن العمل.

فـرب العمـل المـضرور مـن الإضـراب، إذا رفـع دعـى علـى النقابـة للمطالبـة بالتعويض، فيجب أن يثبت الخطأ الذى ارتكبته النقابة ـ على الوجه الذى أوضحناه

(1) Cass. Soc, 22 juin 2004, $N^{\circ}$ de pourvoi: 02-15500,Bull.civ, V, $N^{\circ} 174$, p. 164, disponible sur: www.legifrance.gouv.fr.

- Cass. Soc, 17 juillet 1990, $\mathrm{N}^{\circ}$ de pourvoi: 88-11937, Bull.CIV, V, $\mathrm{N}^{\circ} 375$, p. 224, disponible sur: www.legifrance.gouv.fr.

- Cass. Soc, 21 janvier 1987, ํ de pourvoi: 85-13295, Bull.CIV, V, ํ 27, p. 15, et disponible sur: www.legifrance.gouv.fr.

- Cass. Soc, 23 juin 1988, $N^{\circ}$ de pourvoi: 86-12327, Non publié au bulletin, disponible sur: www.legifrance.gouv.fr.

(2) Cass. CIV 2, 26 octobre 2006, $\mathrm{N}^{\circ}$ de pourvoi: 04-11665, Bull.CIV, 2006, II, $\mathbf{n}^{\circ}$ 299, p. 275, et disponible sur: www.legifrance.gouv.fr. 
سابقا- ولا يكفى أن يثبت خطأ العمـال المضربين لإثبات خطأ النقابة، فكل منهم خطأه

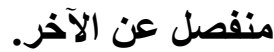

وبالتالي نلاحظ أن محكمة النقض الفرنسية تحساول الحد من مسؤولية النقابـة

عن ممارسة الحق في الإضراب وذلك عن طريق الحد من مفهوم الخطأ الذى ترتكبه النقابة أثناء ممارسة هذا الحق، ويرجع ذلك لرغبة المحكمة في تشجيع النقابـة على

القيام بدورها في الدفاع عن مطالب العمال المهنية.

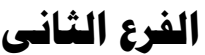

\section{الضرر}

الضرر هو الركن الثاني من أركـان المسئولية التقصيرية، ويقع على عـاتق

المضرور إثبات وقوعه، ويستطيع ذلك باستخدام كافة طرق الإثبات باعتبار أن الضرر

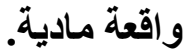

والضرر نوعـان أحدهما مـادي؛ أي الإخلال بحق أو مصلحة مالية للمضرور،

والآخر هو الضرر الأدبي؛ وهو الضرر الذي يصيب الشخص في مصلحة غير مالية حيث يصيبه فى شعوره أو كرامته أو شرفه أو أي معنى آخر من المعاني التى يحرص (1) (الناس عليها. (1)

وفيمـا يتعلـق بممارسـة الإضــراب، فيجب ملاحظـة أن الممارسـة المـشروعة

للإضراب من الطبيعي أن تترتب عليها أضرار مادية لصاحب العمل، وهى الخسارة التي

لحقت به جراء توقف العمل بالمنشأة في وقت الإضراب. (r)

( ) محمد حسين منصور، النظرية العامة للالتزام، مرجع سابق، ص 9 ج".

(2) Adrien LANCIAUX, Op.cit. 
ولكن هذا الضرر لا يمكن التعويض عنـه؛ لأنـه ضـرر مترتب على ممارسـة

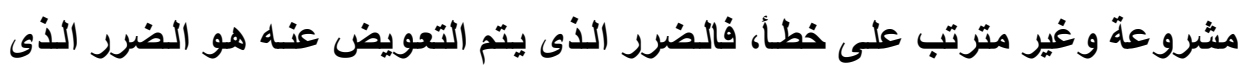
سيترتب على الخطأ الذى ارتكبته النقابة أثناء ممارسة الإضراب. فمن الأضرار التي يمكن أن تترتب على أخطاء النقابـة أثنـاء ممارسـة الإضراب هو الضرر المادى الذى يصيب رب العمل والمتمثل في الخسارة المالية التي أصـابته نتيجة دفع رواتب العمال غير المضربين عن أيام الإضراب رغم عدم عملهم هذه الأيسام؛ لأنهم لم يستطيعوا دخول مكان العمل؛ لأن النقابة حرضت العمال المضربين على إغلاق الق مكان العمل عنوة ومنع العمال من الاخول. (1) وكـنلك قـد يـدعى العــال غيـر المـضربين إصـابتهم بـضرر مــادي أو معنـوي نتيجة الاعتداء عليهم بالسب أو بالضرب من قبل العمال المضربين بناء على تحريض (النقابة.

ومـن ناحيـة أخرى، فقد يـدعى رب العـل بإصـابته بضرر جسيم هو الخسارة المالية نتيجة عدم إخطار النقابة له بالإضراب، مما أدى إلى عدم قدرته على إعداد بديل للعمال المضربين نتيجة لتفاجئه بالإضراب. ومن ناحية ثالثة فقد يدعى الغير المتعامل مع المنشأه إصابته بضرر نتيجة عدم قرتـه على الحصول على الخدمة نتيجة دعوة النقابـة لإضراب غير مشروع، فمثنلاً دعوة النقابة لإضراب الأطباء بالمستثفى الخاص يعد دعوة لإضراب غير مشروع؛ لأن

(1) Cass. Soc, 30 janvier 1991, $\mathrm{N}^{\circ}$ de pourvoi: 89-17332, Bull.civ, $\mathrm{V}, \mathrm{N}^{\circ} 40$, p. 25, Et disponible sur: www.legifrance.gouv.fr.

(2) Cass. Soc, 9 novembre 1982, $\mathrm{N}^{\circ}$ de pourvoi: 80-13958 80-14046 8014097, Bull.Soc, $N^{\circ} 614$, et disponible sur: www.legifrance.gouv.fr. 
المستثفيات لا يجوز فيها الإضراب بناء على قرار رئيس مجلس الوزراء(')، فالمريض الذى تتـدهور حالته جراء عدم حصوله على الخدمـه الطبية يعد مضروراً مـن هذا الإضراب غير المشروع. ودعوة النقابة لإضراب بقصد تعديل اتفاقية العمل الجماعية تعد دعوة لإضراب غير مشروع قد يترتب عليه أضرار مادية جسيمة بصاحب العمل. الفرع الثالثث

\section{علاقة السببية}

لا يكفى لإقامة المسؤولية إثبات ارتكـاب النقابـة لخطأ أثثاء ممارسـة الإضراب وإثبات وجود الضرر الذى أصاب المدعى، ولكن يجب إثبات علاقة السبيية بين الخطأ والضرر، أي يكون الخطأ الذى ارتكبته النقابـة هو الذى أدى إلى إحداث الضرر الذى لى

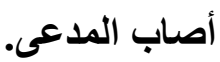

والمشكلة هنـا تتمثل في أن ممارسـة النقابـة للإضـراب يجب أن يترتب عليها

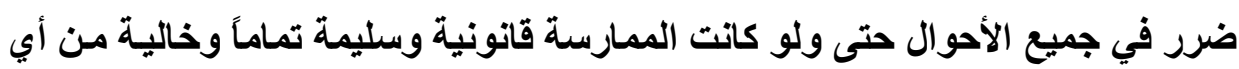
خطأ، ولذلك فعندما ترتكب النقابة خطأ أثنـاء اللدعوة للإضراب أو تنظيمسه، فإنها تكون مسؤولة عن الضرر الذى ترتب عن هذا الخطأ فقطوليس الضرر الذى ترتب عن كل

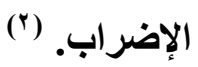

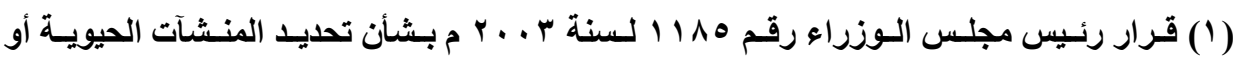

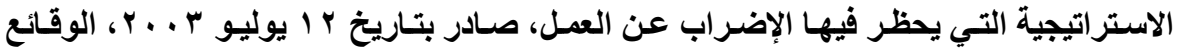

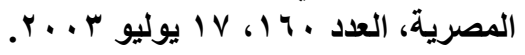

(2) Maxence VERVOORT, Op.cit, P 139. 
وهنـا تكمـن الصعوبة التـي تقع على عـاتق المـدعى في وجوب إثبـات علاقة السببية بين خطأ النقابة أثناء ممارسة الإضراب والضرر المترتب على هذا الخطأ فقط، وليس الضرر المترتب عن كل الإضراب والذى يُعد ضرراً مقبولاً ولن شُسأل النقابـة عن من فئن تعويضه؛ لأنه مترتب عن الممارسة المشروعة للحق في الإضراب. (') فالمدعى يجب أن يثبت علاقة السببية المباشرة بين الخطأ الذى ارتكبته النقابـة والضرر الأى أصابه حتى تُسأل النقابة عن تعويض هذا الضرر.

\section{*اجتماع خطأ النقابة همع خطأ العممال}

من ناحية ثانية يجب أن يثبت المدعى علاقة السببية بين خطأ النقابـة والضرر وليس بين خطأ العمال والضرر، فخطأ النقابة منفصل عن خطأ العمـال، فالأخطاء التي يرتكبها العمال لأُسأل عنها النقابة طالما لم تحرض عليها. (r) فكما ذكرنا سابقاً، فإن النقابة لا تُسأل عن أخطاء العمـال التي يرتكبونها أثناء ممارسـة الإضـراب، طالمـا أن النقابـة لم ترتكب خطـأ أثنـاء اللدعوة للإضـراب أو أثنـاء تنظيمه.

ومن ناحية أخرى فقد تتعدد الأخطاء المسببة للضرر، حيث ترتكب النقابة خطأ معينَاً أثتـاء اللاعوة للإضراب أو تنظيمه،، ويرتكب العمـال خطأ آخر منفصلاً عن خطأ النقابـة أثنـاء ممارسـة ذات الإضـراب، ممـا يثير مسألة إقامـة علاقة السببية بين هذه الأخطاء المتعددة التي ترتب عليها ضرر واحد.

(1) Birame DIOUF, Op.cit, P 332.

(2)Cathy NEUBAUER, L'abus du droit de grève, Art disponible sur: www.village-justice.com/articles/abus-droit-greve,18612.html , La date de mise en ligne est: 5 janvier 2015. 
فهل تقع المسؤولية كاملـة في هذه الحالة على النقابـة أم تتوزع بين النقابـة

للإجابة على هذا التساؤل سنرجع للقواعد العامة في القانون العدنى والتي تحكم حالة اشتراك خطأ الغير مع خطأ المدعى عليه في إحداث الضرر؛ حيث إنه في هذه

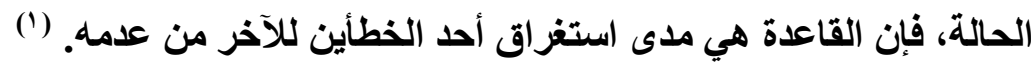
فإذا لم يستغرق خطأ النقابة خطأ العمال اعتبر أن خُلَّا منهمـا سببّ في إحداث الضرر وألتزما بالتعويض متضامنين.

أما إذا استغرق أحل الخطأين الآخر بأن كان خطأ النقابة يفوق في جسامته خطأ

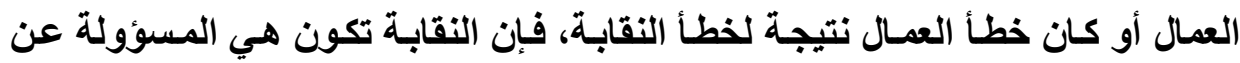
تعويض هذا الضرر.

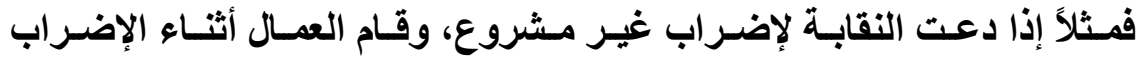
بالتعدى بالسب والقذف على العمـال غير المضربين، فِإن النقابة تكون مسؤولة عن

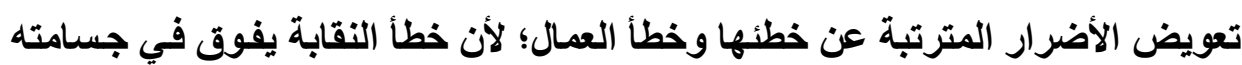

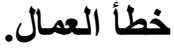

\section{"إثبات علاقة السببية}

ويختلف إثبـات علاقـة السبيبية بـاختلاف الخطأ الذَى ارتكبته النقابـة، فعندما ترتكب النقابة جريمة، فإن علاقة السبيبة تكون سهلة الإثبات من جاتب المدعى، بعكس

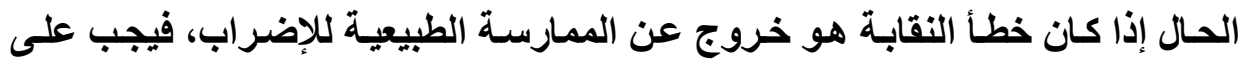
الدعى إثبات علاقة السبيية بين خطأ التظيم والضرر الذى أصابه.

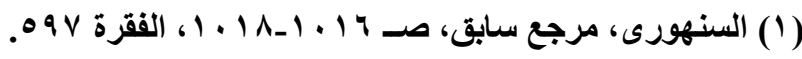


وكذلك الأمر عندما يكون الإضراب الأى دعت إليهه النقابـة غير مشروع - كـأن يكون إضراب للمطالبة بمطالب سياسيةـ فيكون من السهل إثبات إقامـة علاقة السبيية بين الإضراب والضرر الأى يدعيه المدعى.

أمسا عندما يكون الإضراب مشروع وشـابه بعض الأخطـاء مـن جانب النقابـة،

فيكون إثبات علاقة السببية أكثر صعوبة؛ لأنه يجب على المدعى إثبات علاقة السببية بين هذا الخطأ والضرر الذى يدعيه وليس كل الضرر المترتب على الإضراب. وفي حالة إهمال النقابة في تنظيم الإضراب، وعدم قدرتها على منـع العمال من ارتكاب الأخطاء، فإنه من الواجب إثبات علاقة السببية بين إهمال النقابة والضرر الذى الذى أصـاب المـدعى، وهو أمر صعب؛ لأن علاقة السببية تكون واضحة بين خطأ العمـال والضرر وليس بين إهمال النقابة والضرر. (') وهذا قد يكون هو مـا دفع محكمة النقض الفرنسية_كمـا ذكرنـا سـابقاًـ في أن تقرر عدم مسؤولية النقابـة عن الأخطاء السلبية التي ترتكبها أثناء ممارسـة العمـال لملإضر اب. وفيما يتعلق بالضرر المادى الذى يصيب رب العمل والمتمثل في دفعه رواتب العمال غير المضربين الذين تم منعهم من العمل، فبان رب العمل يجب أن يثبت أنهه قـ

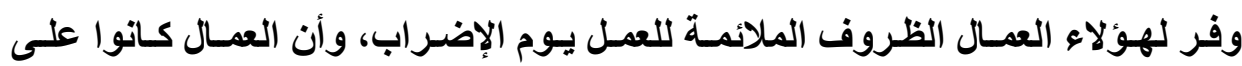
استعداد تام للعمل، وأنهم لم يستطيعوا العمل؛ لأن النقابة قد حرضت العمال المضربين

(1) Jean-Emmanuel RAY, Droit du travail: droit vivant, éd LIAISONS, paris, 17 éd, 2009, P $364, n^{\circ} 340$. 
على غلق مكان العمل ومنع العمال غير المضربين من العمل، أي يجب أن يثبت علاقة السببية بين خطأ النقابة وعدم عمل العمال. (')

وأيضا عندما يدعى العمـال غير المضربين وجود ضرر واقع عليهم نتيجة اعتداء العمال المضربين عليهم، فيجب أن يثبتوا أن تحريض النقابة للعمال المضربين هو الذى أدى إلى الأضرار المادية أو المعنوية التي أصابتهر. وكذلكك الأمر بالنسبة لعـلاء المنشأة المضرورين من هذا الإضراب، فيجب

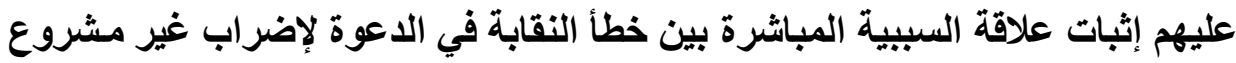

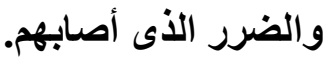

\section{الامطاب الثاني

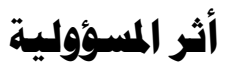

الأثر المترتب على توافر أركان المسؤولية التقصيرية هو حكم القاضي بتعويض المضرور تعويضاً عينياً أو نقدياً.

فإذا قدر القاضي اعتبار دعوة النقابة للإضراب أو تنظيمه بثكل معين يُعد خطأ في ممارسـة الإضراب، فيجوز له أن يحكم بوقف هذا الإضراب إذا كان لم ينته بعدباعتبار أن ذلك يمثل تعويضاً عينياً ـ بجانب الحكم بالتعويض النقدي للمضرور عن الضرر الأى أصابه من هذا الإضراب.

ومقياس التعويض هو الضرر المباثر، فالتعويض سواء أكان تعويضاً نقدياً أو الفوان عينياً يقدر بمقار الضرر المباشر الذى أحثثه سواء أكلان هذا الضرر مادياً أو أدبياً، 
وسواء أكان متوقعاً أو غير متوقع، وسواء أكان حالاً أو مستقبلاً مادام محققاً. ويشتمل

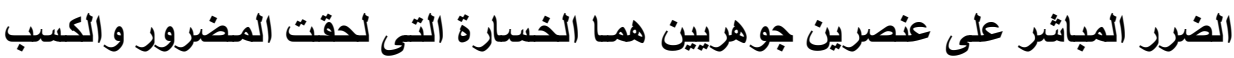

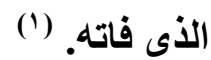

وتكون مهـة القاضسي في تقدير التعويض يسيرة عندما يكون الإضراب غير مشروع - كالإضراب السياسي- حيث يحكم القاضي بتعويض كامل الضرر المترتب على هذا الإضر اب غير المشروع الذى دعت إليه النقابة. فيقوم القاضي بتقير التعويض على أساس الخسارة التي أصابت رب العمل في

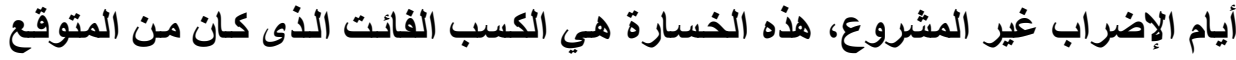

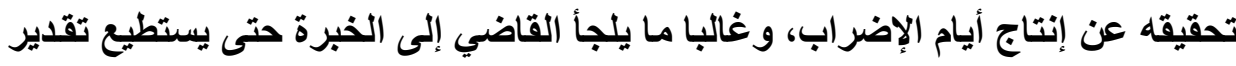

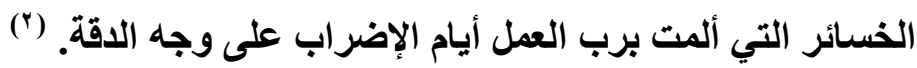

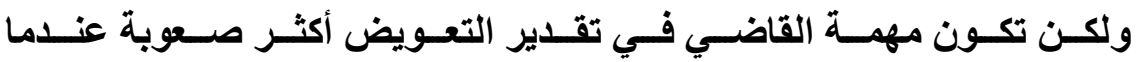

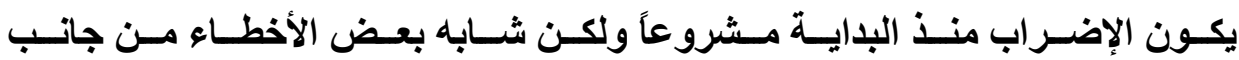

فالفقه يقسم الأضـرار المترتبـة عـن الإضـراب إلـى ضـررين أحـدهـا الضضرر المقبول والآخر هو الضرر غير المقبول، أما الضرر المقبول فهو الضرر المترتب على الاضى الممارسة المشروعة لحق الإضراب، فكما ذكرنا سـابقاً الإضراب يجب أن يترتب عليه ضرر في جميع الأحوال، والضرر غير المقبول هو الضرر الذى يترتب على الممارسة

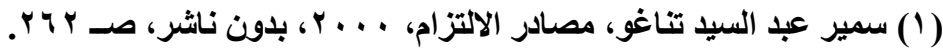
(2) Birame DIOUF, Op.cit, P $3{ }^{r v}$. 
غيـر المشروعة للإضـراب، أي يترتب على الخطـأ مـن جانـب النقابـة في ممارســة

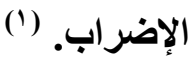

والمشكلة أن الإضراب الواحد قد يترتب عليه ضرر مقبول وضرر غير مقبول، وذلك إذا كان الإضراب مشروعاً وشابه بعض الأخطاء من جانب النقابـة العمالية، فهنـا يجب على القاضسي أن يضع الحد بين الضرر المقبول والضرر غير المقبول ويقوم بتقدير التعويض الذي يجبر الضرر غير المقبول المترتب مباشرة عن خطأ النقابة في ممارسة الإضراب.

فعندما يشوب الإضـراب المـشروع بعض الأخطـاء، يقع على عـاتق القاضـي

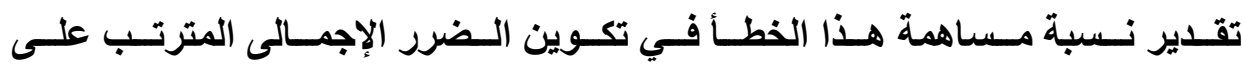
الإضـراب، فعلى أسـاس هـذه النسبة يـتم تحديــ قيمسة التعويض الــى تلتزم النقابـة بالوفـاء بـه، أي أن القاضـي يجب أن يحدد نسبة الـضرر غير المقبـول مـن الـضرر الإجمالى.

وغالبا ما يستعين القاضي في هذه الحالة بالخبير حتى يقوم بتحديد نسبة الضرر غير المقبول المترتب على الخطأ من إجمالي الضرر المترتب على الإضراب بشكل

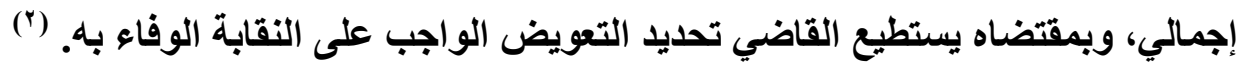
وتطبيقاً لذلك أيدت محكمة النقض الحكم على النقابة العمالية بتعويض الأضرار التي أصابت رب العمل والمتمثلة في دفع أجور العمال غير المضربين بـالرغم من عدم

(1) Blaise HENRY et Chaumette PATRICK, Chronique de Droit social, en: Revue juridique de l'Ouest, 1989-3, pp. 479-492.

(2) Birame DIOUF, Op.cit, P 338. 
قرتهم على العمل يوم الإضراب؛ لأن النقابة قد حرضت العمـال المضربين على منع

العمال غير المضربين من العمل. (1)

فتلتزم النقابة في هذه الحالة بتعويض رب العمل وذلك بأن تدفع له الأجور التي

قام بدفعها للعمال غير المضربين عن الفترة التي قام فيها العمـال المضربون بـإغلاق

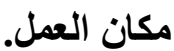

وكذلك تكون مهمة القاضي صعبة عندما يجتمع خطأ النقابة وخطأ العمـال دون أن يستغرق أحدهما الآخر، إذ يجب على القاضي أن يحدد مقدار الضرر المترتب على خطأ النقابة فقط دون الضرر المترتب على خطأ العمال، ويجب أن يحدد مقار التعويض الأي يجبر هذا الضرر المترتب على خطأ النقابة. (r)

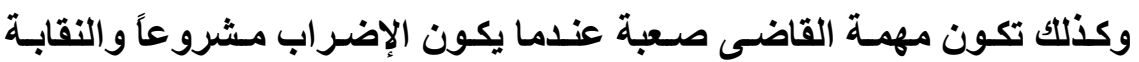
حرضت العمـال على القيام ببعض الأعمـال غير المشروعه، حيث يجب على القاضى تحديد الضرر المترتب على هذا التحريض وتقدير التعويض الكافى لجبره، فالقاضى لن يحكم بجبر كامـل الضرر المترتب على الإضـراب، وإنمسا سـيحم فقط بجبر الضرر المترتب مباشرة على خطأ النقابة.

(1) Cass. Soc, 30 janvier 1991, $\mathrm{N}^{\circ}$ de pourvoi: 89-17332, Bull.civ, $\mathrm{V}, \mathrm{N}^{\circ} 40$, p. 25, Et disponible sur: www.legifrance.gouv.fr.

(2) Maxence VERVOORT, Op.cit, P 140.

(3) Ibid. 


\section{المبحث الثالث}

المسؤولية المدنية عن همارسة النقابة التعسفية للإضراب

بـالرغم مـن أن الحق في الإضـراب هو حق دستورى، إلا أنـه مـن الممكن أن تتوافر حالة أو أكثر من حالات التعسف عند ممارسة هذا الحق، مما يثير التساؤل بمدى إمكانية إثارة مسؤولية النقابة العمالية عن التعسف في ممارسة هذا الحق. (') ولذلك قرر المجلس الاستورى الفرنسي منذ وقت بعيد أن إقرار الدستور للحق في الإضراب لا يعنى إمكاتية الممارسة التعسفية لهذا الحق، فالتعف في ممارسـة هذا

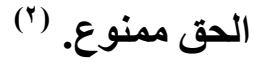
وكذلك أكدت محكمة النقض الفرنسية أن الحق فى الإضراب للمطالبة ببعض المطالب المهنيـة لا يستبعد وجـود قيود على ممارسـة هذا الحق أهمهـا عدم جـواز (التعسف فى ممارستّه. فالعمال ونقاباتهم يجب ألا يتعسفوا فى استعمال حق الإضراب على النحو الذى (كى

يلحق ضرراً بصاحب العمل. (؛)

(1) Cathy NEUBAUER, Op.cit.

(2) CC, décision $n^{\circ} 01645,7$ juillet 1950, RCC, p. 426, et disponible sur : www.conseil-constitutionnel.fr

(3) Cass. Soc, 13 décembre 1962, Bull.civ, IV, $n^{\circ}$ 904, Et disponible sur: www.legifrance.gouv.fr.

(؛) مصطفى أحمد أبو عمرو، التظيم القانونى لحق الإضراب فى القانون المصرى والفرنسي

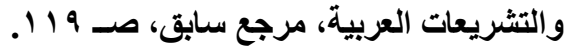


مما لا شك فيه أن دور القاضى فى هذه الحالة يكون فى غايـة الدقة؛ حيث إنـه يـوازن بـين الـضرر الــى أصـاب صـاحب العــل والمطالب المهنيـة التـى تـم الــــوة

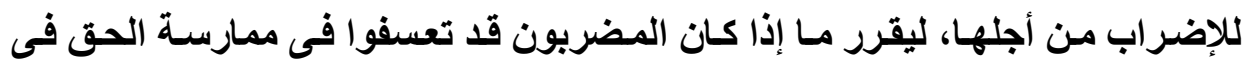
الإضراب من عدمه، ويستعين القاضى فى ذلك بالمعايير التى وضعها القـانون للتعسف فى استعمال الحق. (1) - (1) ومن ناحيته فقد عنى القانون المدني المصري بنظريـة التعسف في استعمال الحق عناية خاصة وأحلها مكاناً بارزاً بين نصوصه، وجعلها نظرية عامة مكانها الباب التمهيدي، حتى يكون لها من العمومية مـا يجعلها تنبسط على جميع نواحي القانون دون أن تكون مجرد تطبيق لفكرة العمل غير المشروع. سنتناول حالات التعف في استعمال الحق ومدى إمكانية انطباقها على ممارسة النقابة لاورها في الدعوة للإضراب وتنظيمه، ثم نتناول أثر تعسف النقابة في ممارسـة الإضراب، وبناء على ذلك، فسوف نقوم بتقسيم هذا المبحث إلى: المطلب الأول: حالات تعسف النقابة في ممارسة الإضراب. المطلب الثاني: أثر تعفف النقابة في ممارسة الإضراب.

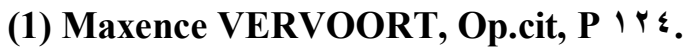
(ץ) المذكرة الإيضاحية للمشروع التمهيدي، مشار إليها فى: السنهورى، الوسيط، مصادر الالتزام،

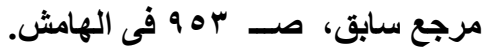




\section{المطلب الأول}

حالات تعسف النقابة في ممارسة الإضراب

وفقاً لنص المادة الخامسة من القانون المدني فإن الثخص يكون قد تعسف في استعمال حقه إذا قصد الإضرار بالغير أو كاتت المصالح التي يرمسي الى تحقيقها غير مشروعة أو كسان الضرر المترتب على ممارسـة هذا الحق تفوق المصلحة المترتبـة عليه.

\section{أولاًّ- قصد الإضرار بالغير:}

إذا كان قصد إحداث الضرر بـالغير هو العامل الأصلي الذي غلب عند صـاحب الحق وهو يستعمل حقه، اعتبر هذا تعسفاً، ولو كـان هذا القصد مصحوباً بنية جلب

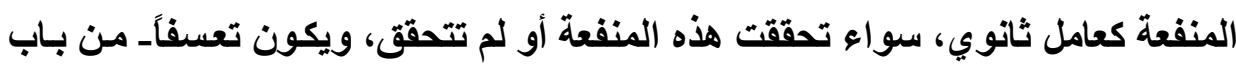
أولىـ قصد إحداث الضرر غير المقترن بنية جلب المنفعة حتى لو تحققت هذه المنفعة عن طريق عرضي. (1) ع (1) فتُعد النقابـة متعسفة في ممارسـة الإضراب إذا دعت لإضراب لمجرد الإضرار برب العمل ودون أن يكون الهدف هو تحقيق المطالب المهنية للعمال؛ وذلك لأن النقابـة تعرف منذ البداية أن هذه المطالب لن يستطيع رب العمل إجابتها. 
فإذا كان الهُف من الإضراب هو مجرد إحداث ارتباك داخل مكان العمل وتعطيل الإنتـاج، فـإن هذا الإضـراب مـن الممكن أن يُعد إضـراباً تعسفياً طالمـا أن الهـف هو

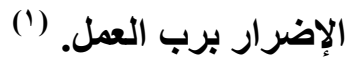

وتطبيقـا لـلكك؛ فقد أكدت محكمـة النقض الفرنسية أن النقابـة العماليـة تكـون

متعسفة في ممارسـة الحق في الإضـراب إذا كـان هدفها مـن هذا الإضـراب هو فقط

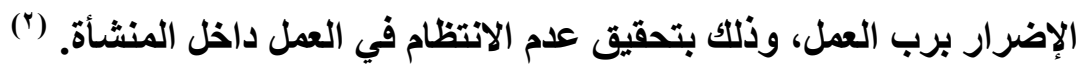

ولكن يجب أن يُلاحظ هنـا أن عدم انتظام العمل في المنشأة لا يعتبر تعسفاً في

ممارسـة الحق في الإضراب في جميع الأحوال؛ لأن الإضـراب في صسورته الطبيعيـة المشروعة من الممكن أن يترتب عليه عدم انتظام في العمل بالمنشأة، فلا يكون ذلك التك

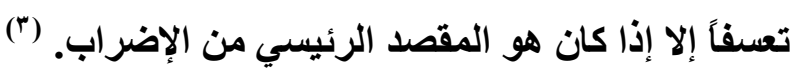

وتظهر الطبيعة التعفية للإضراب جلية عندما تكون المطالب التى قام من أجلها

الإضراب هـ مطالب وهمية، وأن الهـف الحقيقي للإضراب هو فقط الإضرار برب

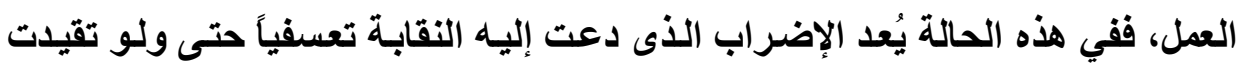

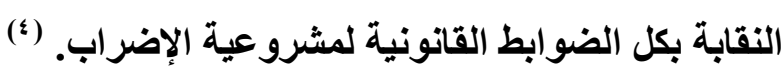

(1) Clara SOUDAN, La Grève: étude comparative en droit français et en droit italien, Art disponible sur; www.u-paris10.fr, La date de mise en ligne est: 14/02/2013.

(2) Cass. Soc, 18 janvier 1995, $\mathrm{N}^{\circ}$ de pourvoi: 91-10476, Bull.civ, $\mathrm{V}, \mathrm{N}^{\circ} 27$, p. 18, Et disponible sur: www.legifrance.gouv.fr.

(3) Cathy NEUBAUER, Op.cit.

(4) Maxence VERVOORT, Op.cit, P 124. 


\section{ثانيًا - رجحان الضرر على الصلحة رجحانًا كبيراً:}

المعيار هنا هو موضوعي، وهو معيار السلوك المألوف للشخص العادي، فليس

من المألوف للشخص العـادي أن يستعمل حقاً على وجهه يضر بـالغير ضرراً بليغاً ولا يكون لـه في ذلك إلا مصلحة قليلة الأهميـة لا تتناسب البتـة مـع هذا الضرر، فيكون استعمال الشخص لحقـه تعسفاً إذا كانت المصالح التي يرمسى لتحقيقها قليلـة الأهمية بحيث لا تنتاسب البتة مع ما يصيب الغير من ضرر بسببها. (1) فقد تُعتبر الدعوة للإضراب تعسفاً إذا لم يكن هنـاك تناسب بين الضرر المترتب على الإضراب والمطالب المرجو تحقيقها من هذا الإضراب، بحيث تكون المطالب تافهة

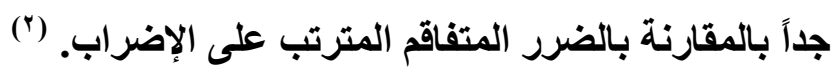
فممارسة الحق فى الإضراب يجب أن تكون فى إطار مراعاة المصالح الأخرى

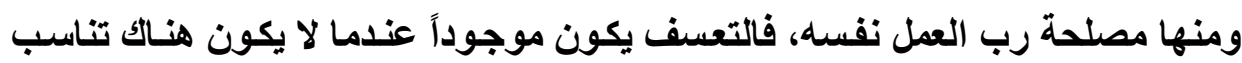

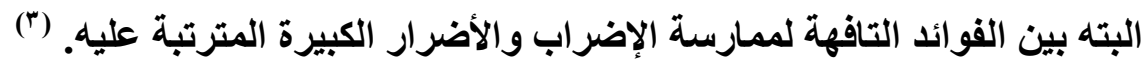
ولذلك تعد النقابة متعففه في ممارسة الحق في الإضراب إذا هي دعت العمـال للإطالـة من مدة الإضراب زيـادة عن الحـ المعقول بمـا يسبب أضرارً لرب العمـل لا تتناسب مع مطالب العمال من هذا الإضراب.

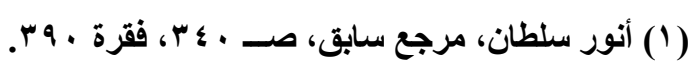

(2) Anne-Lise Mougel-ZABEL, Prérogatives et responsabilités des institutions du personnel d'entreprise : contribution à la théorie des droits-fonctions, Thèse Présentée pour l'obtention du grade de Docteur en droit, Faculté de droit, université paris Est, 2010, P 223.

(3) Ibid, P 216. 
فقد اعتبرت محكمـة النقض الفرنسية النقابـة متعسفة في ممارسـة الحق في

الإضر اب؛ لأنها قامت بالدعوة للإضراب عدة مرات في مدة زمنية قصيرة، حيث نظمت

الإضراب بحيث يكون مرتين يومياً كل مرة لمدة سـاعة وذلك طيلة شهر كامل، ممـا

ترتب عليـه أضـرار لـرب العمـل لا تتناسـب البتهـه مـع المطالب المبتفى تحقيقها مـن

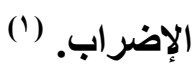

ومن ناحية أخرى فإن الوقت الأى تختاره النقابة يمكن أن يؤدى للقول بوجود

تعسف من ناحيتها فى ممارسة الإضراب، كأن يكون هذا الوقت هو أكثر أوقات السنة

(كتظاظاً بالعملاء فى منشأة رب العمل.

فالتوقيت الذى تختاره النقابة للاعوة إلى الإضراب قد يؤدى إلى وصف الدعوة

للإضر اب بالتعفية، خاصة إذا كان هذا الوقت استثنائياً بالنسبة للمنشأة، كأن تكون

المنشأة فحى حالـة طوارئ وتقوم النقابـة بالـدعوة للإضـراب، فالـضرر المترتب على

الإضر اب في هذه الأحوال لا يتناسب مطلقاً مع المطالب المهنية للعمال. (َ)

(1) Cass. Soc, 13 décembre 1962, Bull.civ, $N^{\circ}$ 904, Et disponible sur: www.legifrance.gouv.fr.

(2) Brill-Venkatasamy TARA, La prévention des dommages et la cessation de la situation illicite en matière de conflits collectifs du travail : comparaison des droits anglais et français, en: Revue internationale de droit comparé, Vol. 46, $\mathrm{N}^{\circ} 4$ ، Octobre-décembre 1994, pp. 1107-1131.

(3) Anne-Lise Mougel-ZABEL, Op.cit, P 216. 
ولذلك اعتبرت محكمة النقض الدعوة للإضراب دعوة تعسفية عندما لا تراعى الأوقـات الحرجـة للمنشأة، لأنها يترتب على هذا الإضراب ضرر كبير لا يتناسب مـع المصالح المبتغى تحقيقها من هذا الإضراب. (1) من ناحيـة أخرى فقد تعد النقابـة متعسفة في الدعوة إلى الإضراب إذا دعت للإضر اب أثناء الوسـاطة أو التحكيم، فقد نصت المـادة (L2522-2) من قـانون العمل الفرنسي على أنه يجب على أطراف المنازعة العمالية أن يقدموا كل التسهيلات الممكنة للوسطاء الذين يقومون بمحاولة حل النزاع حتى تتجح مهتهم.

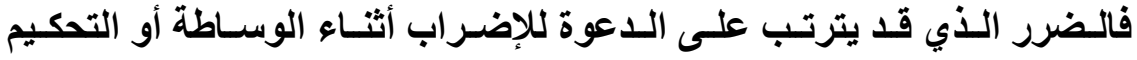
والمتمثل في فثل هذه المساعى الودية لفض النزاع قد يفوق المصالح المبتفى تحقيقها

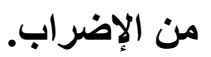
ولذلك حظر قانون العمل المصري اللجوء للاضراب أثناء الوسـاطة أو التحكيم وفقاً لصريح نص المادة به 19، فقيام العمـال بالإضراب أثناء الوسـاطة أو التحكيم هو عمل غير مشروع ويعتبر خطأ يثير المسؤولية المدنية للعامل إذا توافر الضرر وعلاقة السببية بينهما.

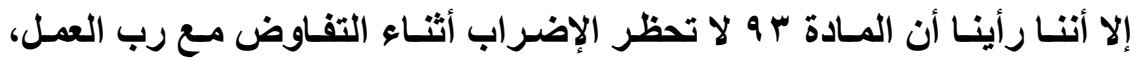
فالإضراب أثناء التفـاوض يُعد أمراً مُباحسا، وإن كـان من الممكن اعتبار هذا الإضراب الإبراب تعسفاً في استعمال الحق؛ وذلك لأن النقابـة العماليـة يجب أن تعـل على نجـاح هذه المفاوضـات وليس عرقتهها، فتعد اللدعوة للإضراب أثناء تلكك المفاوضـات تعسفاً في

(1) Cass. soc. 25 octobre 1979, $n^{\circ}$ 78-13528, Bull.Soc, $n^{\circ}$ 786. Et disponible sur: www.legifrance.gouv.fr. 
استعمال حق الإضراب؛ لأن الضرر الأي قد يترتب عليه والمتمثل في فشل المفاوضـات مع رب العمل قد يفوق المصالح المبتغاة من الإضراب.

\section{ثالثًا- عدم هشروعية المسالج التى يرهى صاحب الحق إلى تمقيقها:}

ليس من السلوك المسألوف للشخص العـادي أن يسعى إلى تحقيق مصالح غير مشروعة تحت ستار أنه يستعمل حقاً له، فذلك يعد تعسفاً في استعمال هذا الحق؛ لأنـه

يهدف من ورائه إلى تحقيق غرض غير مشروع. (')

فقيـام النقابـة بالـدعوة لإضــراب لمطالبـة رب العمـل بـبضض المطالب التـي لا

يفرضـها القـانون على رب العـل هو ممارسـة تعسفية للإضـراب؛ لأن النقابـة تطالب

$$
\text { بمطالب لا يُلزم القانون رب العمل بتحقيقها. }
$$

كذلك قيـام النقابـة بالدعوة لإضـراب دون أن تكون هنـاك مطالب حقيقيـة لهـذا الإضراب، ولكن مجرد مجموعة من المطالب غير الجدية، يعد نوعاً من أنواع التعسف

$$
\text { في ممارسة الحق في الإضراب. }
$$

وكذلك يعد تعسفاً فى ممارسة الإضراب الدعوة لإضر اب للمطالبة بمطالبات غير

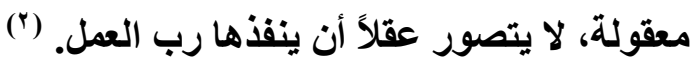

فممارسة الحق فى الإضراب يقيدها الالتزام بحسن النية والذى يقتضى أن تكون

المطالبات التى قام من أجلها الإضراب هى مطالبات معقولة، فالمطالبـات غير المعقولية

يمكن أن تتسبب في وصف ممارسة الإضراب بالتعسف فى استعمال هذا الحق. (r)

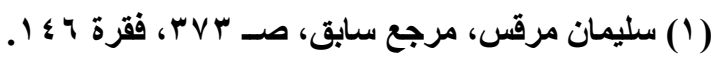

(2) Anne-Lise Mougel-ZABEL, Op.cit, P 217.

(3) Maxence VERVOORT, Op.cit, P 42. 


\section{الإطلب الثاني \\ أثر التهسف في ممارسة الإضراب}

يتمثل الجزاء على التعسف في استعمال الحقى فى التعويض عن الأضـرار

المترتبة عليه سواء اتخذ هذا التعويض صورة نقدية أو عينية. (1)

وبناءً على ذلك، فِان القاضي إذا قدر اعتبار دعوة النقابـة للإضراب أو تنظيمها

بشكل معين تعسفاً في ممارسـة الحق في الإضـراب يجـوز لـه أن يحكم بوقف هـذا

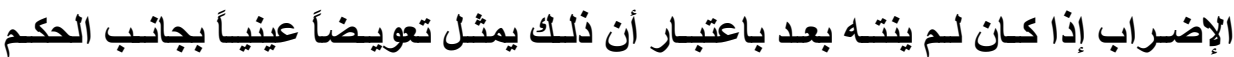
بالتعويض النقدي للمضرور عن الضرر الذى أصابه من هذا الإضراب. وممـا لا شـك فيـه أن تقدير وجـود حالـة مـن حساتلات التعسف في استعمال حق الق الإضر اب من جانب النقابة هو أمر دقيق جداً نظراً لأن حق الإضراب هو حق دستوري، لألك فإن القاضى عندما يقوم بتقدير مدى وجود تعسف في ممارسة الإضراب من عدمه يجب أن يضع فى اعتباره كل الظروف التى تم ممارسة الإضراب فى ظلها ومدى جديـة المطالب التى تم الدعوة للإضراب للمطالبة بها، وكذلك الضرر الذى يصبب المدعى مـع

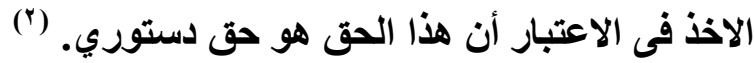
ومقياس التعويض هو الضرر المباشر، فالتعويض يقدر بمقدار الضرر المباشر الأى أحلثه سواء أكان هذا الضرر مادياً أو أدبياً، وسواء أكسان متوقعاً أو غير متوقع،

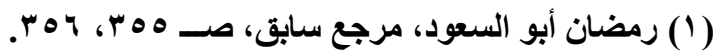
(2) Brill-Venkatasamy TARA, Op.cit. 
وسواء أكـان حسالًا أو مستقبلًا مسادام محققاً، ويشتثل الضرر المباشر على عنصرين

جوهريين هما الخسارة التى لحقت المضرور والكسب الأى فاته. (1) أي أن القاضسي سـيحكم بجبـر الـضرر المترتـب فقط على تعسف النقابـة في ممارسة الإضراب دون أن يحكم بجبر كامل الضرر المترتب على الإضراب، إلا إذا قدر القاضي أن الدعوة للإضراب كانت تعففاً من جانب النقابـة، فقي هذه الحالـة قد يحكم القاضي بجبر كامل الضرر المترتب على هذه الدعوة التعسفية للإضراب. فالمهم هنا هو أن القاضي سيحدد الضرر المترتب مباشرة على تعسف النقابـة في الدعوة للإضراب أو المترتب على تعسف النقابة في تنظيم الإضراب، وهذا الضرر هو الأي يحكم القاضي بجبره فقط، أمسا بـاقي الضرر المترتب على الإضراب فلا يحكم القاضـي بـالتعويض عنـه، فمقدار التعويض يكون على أسـاس مقدار الضرر المباشر المترتب على التعف في الدعوة للإضراب أو التعف في تنظيم الإضراب. 


\section{الفصل الثالث}

\section{المسؤولية المدنية للعاهل عن همارسة الإضراب}

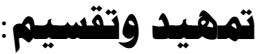

الحق الذي يُمنح للعمال في الإضراب يجب أن يقابله مسؤولية هؤلاء العمال في

حالة الممارسة غير المشروعه لهذا الحق. (1)

فخروج العامـل عن الضوابط المرسومة لممارسـة الحق في الإضراب قد تعد

خطأ، مما يؤدى إلى مسؤوليته عن الأضرار المترتبة على هذا الخطأ.

وكذلك من الممكن تصور تعسف العامل في ممارسـة الحق في الإضراب، ممـا

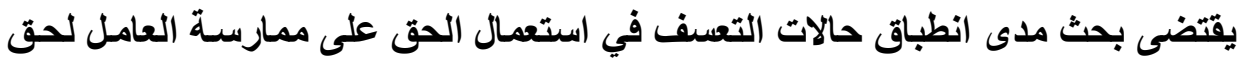

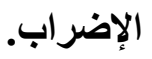

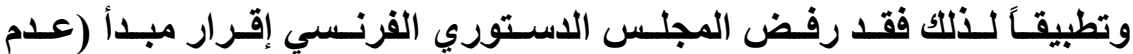

المسؤولية الجنائيـة أو المدنيـة) للعمـال المضربين عن العمل، وقرر عدم دسـتورية

النص على مبدأ عدم المسؤولية في التشريع، بالرغم من إقراره بأن الحق في الإضراب

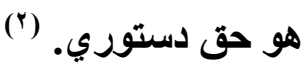

(1) Birame DIOUF, Op.cit, P 57.

(2) CC, décision $n^{\circ}$ 82- 144, 22 Octobre 1982, RCC, p. 61, et disponible sur : http://www.conseil-constitutionnel.fr/conseil-con..decision-n-82-144-dcdu-22-octobre-1982.8004.html. 
فقد وازن المجلس الاسـتورى بـين الحق الدستورى ومبـدأ المسوؤلية عـن ممارسة هذا الحق، فكون الحق دستورياً لا يمنع من إقرار المسؤولية القانونية عن

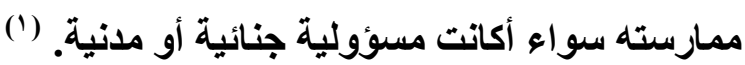
حتى نتناول هذه النقاط، فسوف نقوم بتقسيم هذا الفصل إلى: المبحث الأول: المسؤولية المدنيـة للعامـل عـن الممارســة غيـر المـشروعة للإضضراب المبحث الثاني: تعسف العامل فى ممارسة حق الإضراب.

(1) Didier Le PRADO, Les fondements constitutionnels et juridiques d'un droit à la réparation du préjudice corporel, Art disponible sur: www.courdecassation.fr, La date de mise en ligne est: 05-12-2006.

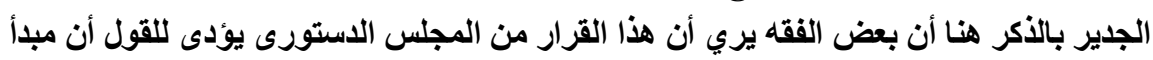
تعويض المضرور يرتفع لمصاف المبادئ الاستورية، انظر:-

Nicolas MOLFESSIS, Sur trois facettes de la jurisprudence du Conseil constitutionnel, Les Nouveaux Cahiers du Conseil constitutionnel, 2011/2, ${ }^{\circ}$ 31, p. 5-19.

Christophe RADÉ, "Liberté, égalité, responsabilité " dans la jurisprudence du Conseil constitutionnel, Cahiers du Conseil constitutionnel, $n^{\circ} 16$, juin 2004 , 


\section{المبحث الأول}

\section{المسؤولية المدنية للعاهل عن المهارسة غير المشروعة للإضراب}

إذا خرج العمال عن ضوابط ممارسة الإضراب، وترتب على ذلك أضرار بأي

شخص، فمن حق هذا المضرور أن يطالب بتعويض العمال له عن الضرر الذي أصابه، وهو مـايثير التساؤل عن طبيعة مسؤولية العامل عن الإضراب في حالة مـا إذا كان المضرور هو رب العمل، فهل المسؤولية تكون مسؤولية عقدية أم تقصيرية؟ فحتى نجيب عن هذا التساؤل فسوف نتناول أسـاس المسوؤية المدنية للعامل عن ممارسـة الإضراب عن العمل، ثم نتنـاول أركـان المسؤولية، وأخيرا نتــاول آثار المسؤولية، ويناء على ذلك فسوف نقوم بتقسيم هذا المبحث إلى: المطلب الأول: أساس المسؤولية.

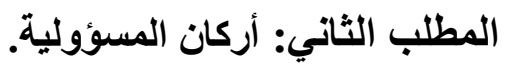
المطلب الثالث: أثر المسؤولية.

\section{المطاب الأول \\ أساس المسؤولية}

ذكرنـا ســابقًا أن هنــاك ضـو ابط لممارســة حـق الإضــراب، فـإذا التـزم العامـل

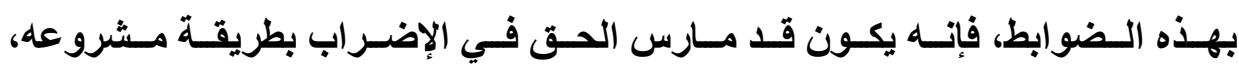

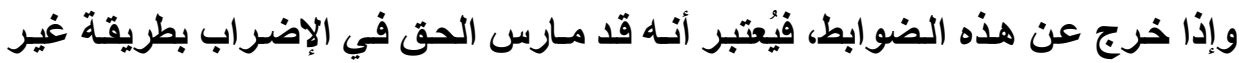

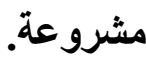


ولم يختلف الفقه الفرنسي على أساس مسؤولية العامل عن ممارسـة الحق فى الإضراب، فالققه الفرنسي يُجمع على أن أسساس مسؤولية العامل عن أضرار إضرابه عن العمل هو المسؤولية التقصيرية وليس المسؤولية العقدية سواء أكان المضرور هو الإني رب العمل أو غيره، ويختلف الفقه الفرنسي فى السند القانونى لذلك.

فيرى جانـب مـن الفقـه أن عقدـ العمـل يتوقف جزئيساً أنثـاء ممـارســة العامـل

للإضر اب، بحيث لا تكون هناك علاقة تبعية بين العامل ورب العمل، ولكن يظل العامل

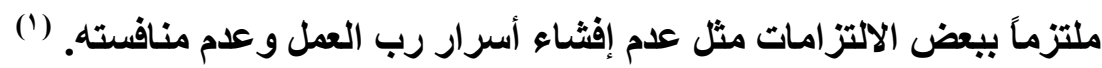

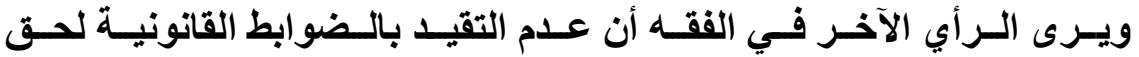
الإضر اب يعد خطأ تقصيريَّا يستوجب مساعلة العامل تقصيرياً وليس تعاقدياً؛ لأن العامل عندما يخـالف ضـوابط الحق في الإضـراب فهو يخـالف التزامـاً قانونيَّاً وليس التزامـاً (ن) عقديَّاً. ومحكـة النقض الفرنسية أكلدت في أحكامها على أن مسؤولية العامـل عن الأضرار المترتبـة عن إضرابه عن العمل هى مسؤولية تقصيرية أيـا كـان المضرور سواء أكان صاحب العمل أو العمـال الآخرين غير المضربين أو عملاء منشأة صـاحب

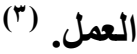

(1) Vincent Neuprez, Michel Deprez, Contrats de travail: l'essentiel, éd edipro, Belgique, 2013, p 140, $\mathrm{n}^{\circ} 206$.

- Jean MOULY, Droit du travail, éd Breal, Paris, 4 éd, 2008, P 131- 133.

- Jean-Emmanuel RAY, Op.cit, P 213 et S.

- Gaston NADEAU, Le statut juridique du salarié-gréviste Québécois, Presses de l'Université Laval, québec, 1981, $P 40$ et $\mathrm{S}$.

(2) Anne-Lise Mougel-ZABEL, Op.cit, P 349.

(3) Maxence VERVOORT, Op.cit, P 129. 
ويعد حكم (FONTAINE) هو أول حكم يصدر عن محكمة النقض الفرنسية

مقرراً مبدأ مسؤولية العمال المضربين عن أضرار الإضراب عن العمل؛ حيث أيد الحكم بالتعويض على ستة عمال قاموا بالإضراب عن العمل، وقاموا بإغلاق أبواب المصنع ومنع باقى العمال غير المضربين من القيام بالعمل بالمصنع مما دفع صاحب العمل لعدم دفع أجور كل العمال عن أيام الإضراب، فطالب العمال غير المضربين الحكم على الستة عمال المضربين عن العمل بدفع تعويض لهم يساوى أجر أيام الإضراب، وهو مـا أيدته

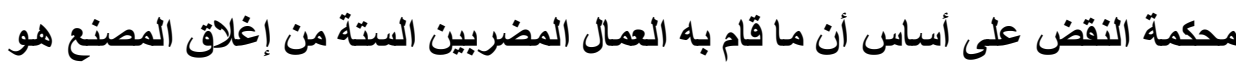

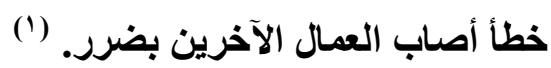

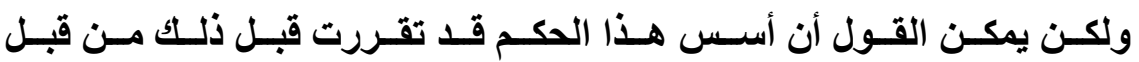
محكمة النقض الفرنسية عندما رفضت مـنح حصانة للعمـال المضربين عن العـل

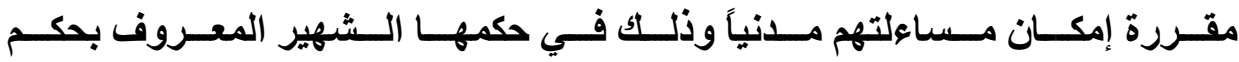

(`) (CORFU)

وقـد قـررت محكمـة الـنقض سـابقًا أن الحـق فـي الإضـراب هـو حـق فـردى

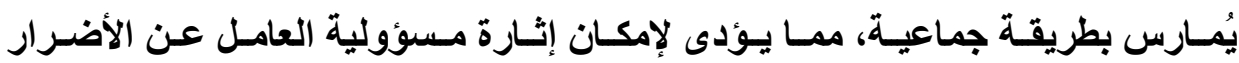

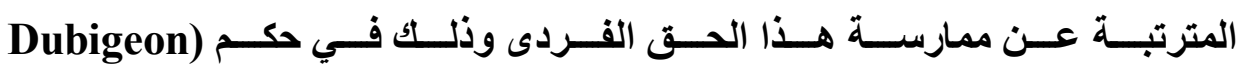

(r) .(-Normandie

(1) Cass. Soc, 8 décembre 1983, $N^{\circ}$ de pourvoi: 81-14238, Bull.soc, $n^{\circ}$ 598, et disponible sur: www.legifrance.gouv.fr

(2) Cass. Soc, 8 février 1972, $N^{\circ}$ de pourvoi: 71-40285, Bull.soc, $n^{\circ} 113, P$. 105. et disponible sur: www.legifrance.gouv.fr

(3) Cass. Soc, 9 novembre 1982, $N^{\circ}$ de pourvoi: 80-13958 80-14046 8014097, Bull.soc, $N^{\circ}$ 614. et disponible sur: www.legifrance.gouv.fr 


\section{المطاب الثاني

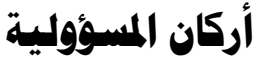

رأينـا في المطلب السـابق أن أسـساس مسؤولية العامـل عن أضـرار ممارســة الإضراب هو المسؤولية التقصيرية، فأي خطأ يترتب عليه ضرر يقتضى الحكم على المخطئ بتعويض المضرور أيا كان هذا الخطأ، فهذه القاعدة العامـة تنطبق على أيـة واقعة تمثل خطأ بما فيها واقعة الإضراب عن العمل. وحتى تتحقق مسؤولية العامل في هذه الحالة فيجب أن يتو افر ثنلاث أركان وهم الخطأ والضرر وعلاقة السبيية. فهل يمكن أن تتحقق هذه الأركان في حالة خروج العامل عن ضوابط ممارسـة الحق في الإضراب. سوف نجيب عن هذا السؤال من خلال تقسيم هذا المطلب إلى ثلاثة فروع:

$$
\text { الفرع الثاني: الضرر. }
$$

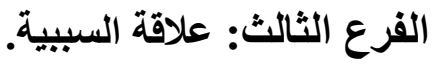




\section{الفرع الأول}

|lil|

دائمسا مـا يترتب على الإضراب أضرار لصساحب العمل، هذه الأضرار لا يمكن

مساعلة المضربين عليها إلا إذا كانت ناشـئة عن إضراب غير مشروع أو إذا تخليل

الإضر اب أعمال غير مشروعة تمثل خطأ. (1)

ووفقاً للقواعد العامة في القانون المدنى، فِان أي خطأ يترتب عليه ضرر يلزم

مرتكب الخطأ بالتعويض حتى ولو كان الخطأ بسيطاً، وهذه القاعدة من العمومية بحيث تنطبق على الإضراب عندما يتخلله خطأ أدى إلى ضرر.

إلا إن المـادة (L2511-1) مـن قانون العمل الفرنسي اشتثرطت ارتكـاب العامل

لخطأ جسيم أثناء الإضراب حتى يمكن توقيع جزاء الفصل عليه.

وبالرغم من أن نص المادة (L2511-1) من قانون العمل الفرنسي صريحة في

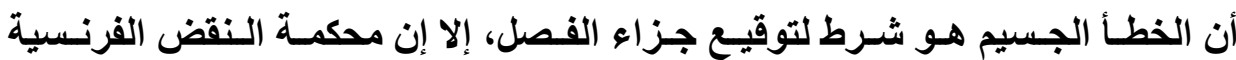

استقرت على اشتراط ارتكاب العامل لخطأ جسيم أثناء الإضراب، حتى يمكن توقيع أي

جزاء تأديبي آخر على العامل بما فى ذلك الإنذار. (؟)

(1) Pauline DISDIER, Les problèmes de responsabilité liés au droit de grève, Art disponible sur: www.comite-entreprises.eu, la date de mise en ligne est: 17 octobre 2012.

(2) Cass. Soc, 18 janvier 2017, $N^{\circ}$ de pourvoi: 15-19309, Non publié au bulletin, et disponible sur: www.legifrance.gouv.fr

- Cass. Soc, 12 janvier 2016, № de pourvoi: 14-10668, Non publié au bulletin, et disponible sur: www.legifrance.gouv.fr

- Cass. Soc, 9 mai 2012, $N^{\circ}$ de pourvoi: 10-24307, Bull.civ, $V$, ${ }^{\circ} 131$, et disponible sur: www.legifrance.gouv.fr.

$=$ 
ومن جانبه ، فإن قانون العمل المصري اعتبر أن عدم مراعاة العمـال للضوابط

التى تنظم الإضراب هو من قبيل الخطأ الجسيم الذى يجيز لرب العامل فصل العامل،

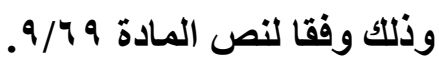

وتطلب قانون العمل لشرط الخطأ الجسيم يرجع إلى الطبيعة الدستورية لحق

الإضراب، حيث لا يكفي أن يرتكب العامل مجرد خطأ بسيط أثناء الإضراب حتى يمكن

إقامة مسؤوليته التأديبية عن هذا الخطأ، بل يجب أن يكون الخطأ جسيماً حتى تثور

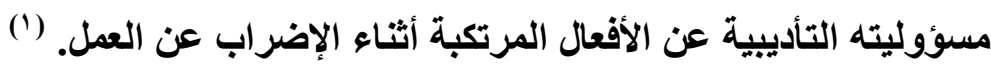

والغرض من هذا الدكم هو منح العامل حصانة تأديبية أثناء قيامـه بالإضراب،

بحيث أنه لا يُسأل تأديبيا عن الأخطاء البسيطة المرتكبة أثنـاء الإضراب، ولكن يُسأل

فقط عن الخطأ الجسيم، وذلك حتى لا تكون المسؤولية التأديبية سيفاً مسلطاً على رقاب

العمال المضربين عن العمل، فيكون ذلك عائقاً لممارسة هذا الحق الدستوري.

- Cass. Soc, 9 octobre 2012, $\mathrm{N}^{\circ}$ de pourvoi: 11-17829, Bull.civ, $\mathrm{V}, \mathrm{n}^{\circ} \mathbf{2 5 3}$, et disponible sur: www.legifrance.gouv.fr.

- Cass. Soc, 9 mars 2011, $N^{\circ}$ de pourvoi: 09-42150, Bull.civ, $V$, $n^{\circ} 69$, et disponible sur: www.legifrance.gouv.fr.

- Cass. Soc, 18 septembre 2007, $N^{\circ}$ de pourvoi: 06-41761, Non publié au bulletin, disponible sur: www.legifrance.gouv.fr.

- Cass. Soc, 16 décembre 1992, $\mathrm{N}^{\circ}$ de pourvoi: 91-41215, Bull.civ, V, $\mathrm{N}^{\circ}$ 592, p. 373. et disponible sur: www.legifrance.gouv.fr.

- Cass. Soc, 7 juin 1995, $N^{\circ}$ de pourvoi: 93-42789, Bull. Civ, V, No 181, p. 133. et disponible sur: www.legifrance.gouv.fr.

(1) Yacouba SANGARE, Les Sanctions en Droit du travail : étude comparative du droit français et du droit malien, thèse pour obtenir le grade de docteur d'etat en droit, faculté de droit, université de CergyPontoise, 2012, P 130. 


\section{| المقصود بالخطأ البسيميم *}

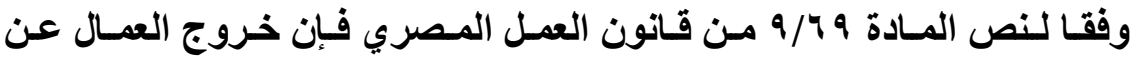
الضوابط التى تنظم حق الإضراب والواردة فى المواد من ب 9 ا ـ ـ 19 من قانون العمل، هو بمثابة الخطأ الجسيم الأى يجيز فصل العامل. فأي خروج عن الضوابط التي وضعها قانون العمل للإضراب يعد خطأ جسيماً، فمثلاً الخروج عن سلمية الإضراب يعد خطأ جسيماً، لأن المـادة ب 9 أ صريحة في أن الإضراب يجب أن يكون سلمياً.

وإذا كان قانون العمل الفرنسي قد اشترط الخطأ الجسيم كشرط لإقامـة مسؤولية العامل التأديبية عن الأخطاء المرتكبة أثناء الإضراب، فهو لم يحدد المقصود بهذا الخطأ الجسيم لممارسة الحق في الإضراب، فيقع على عاتق القضاء تحديد المقصود به. وقد استقرت محكمة النقض الفرنسية على أن الخطأ الجسيم للعامل المضرب عن العمل هو السلوك الأي يتميز بالخطورة مثل العنف من قبل العامل المضرب تجاه العمال غير المضربين أو عرقلة سير العمل بالمنشأة من قبل العامل المضرب. ( ) ويترتب على ذلك أن أي خطأ يرتكبه العامل المضرب عن العمل أثناء الإضراب، ولا يعد خطأ جسيماً لا يترتب عليه مسؤوليته التأديبية، فالعامل لا يمكن أن يُسأل إلا في

(1) Cass. Soc, 10 février 2009, $N^{\circ}$ de pourvoi: 07-43939, Non publié au bulletin, disponible sur: www.legifrance.gouv.fr.

- Cass. Soc, 16 novembre 1993, $\mathrm{N}^{\circ}$ de pourvoi: 91-41024, Bull civ, $\mathrm{V}, \mathrm{N}^{\circ}$ 268, p. 183, et disponible sur: www.legifrance.gouv.fr.

- Cass. Soc, 23 mai 1995, $N^{\circ}$ de pourvoi: 93-45159, Non publié au bulletin, disponible sur: www.legifrance.gouv.fr. 
فقانونـا العمل المصري والفرنسي يعترفـان للعامل المضرب بـالحق في ارتكـاب خطأ بسيط مقبول وفقا للظروف المحيطة بالإضراب، فالقانون قد منح العامل المضرب حصانة أثناء الإضراب تتمثل في عدم مساءلته تأديبياً عن أي أخطاء بسيطة يرتكبها أثناء الإضراب عن العمل.

\section{الفطأ كركن للامسؤولية}

إذا كـان قـانون العمل قد اشـترط الخطأ الجسيم كشرط لإقامـة مسؤولية العامل التأديبية عن الأخطاء المرتكبة في الإضراب، فهل يكون الخطأ الجسيم شرطاً لإقامـة المسؤولية المدنية عن أضرار الإضراب عن العمل؟

الإجابـة تكـون بـالنفي؛ وذلكـ لأن نـص المـادة (L2511-1) مـن قـانون العـل الفرنسي ونص المادة 9 9 /9 من قانون العمل المصري صريحتان في أن الخطأ الجسيم هو شرط لتوقيع جزاء الفصل، ولم يـأكر قـانون العمل الخطأ الجسيم كشرط لإقامـة

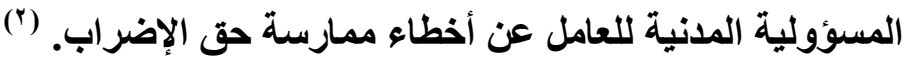

وحيث إن قانون العمل ـوهو قانون خـاص- لـم يضع تنظيمـاً خاصـاً لمسؤولية العامل المدنية عن ممارسة الحقى فى الإضراب، فيجب الرجوع هنـا إلى القواعد العامـة للمسؤولية المدنيـة الواردة فى القـانون المدنى والتى لا تشترط سـوى الخطأ البسيط لإقامة المسؤولية المدنية.

(1) Cass. Soc, 22 janvier 1992, $\mathrm{N}^{\circ}$ de pourvoi: 90-44249, Bull civ, $\mathrm{V}, \mathrm{N}^{\circ} \mathbf{1 9}$, p. 12, et disponible sur: www.legifrance.gouv.fr.

- Cass. Soc, 16 décembre 1992, $N^{\circ}$ de pourvoi: 91-41215, Bull civ, $V, N^{\circ}$ 592, p. 373, et disponible sur: www.legifrance.gouv.fr.

(2) Anne-Lise Mougel-ZABEL, Op.cit, P 349. 
كما أن محكمة النقض الفرنسية لم تشترط الخطأ الجسيم إلا لتوقيع الجزاءات

$$
\text { التأديبية على العامل والواردة فى قانون العمل. }
$$

وبالتـالى فارتكـاب العامـل لخطـأ سـواء أكسان بسيطاً أم جسيماً يـؤدى لإمكانيـة

إقامـة مسؤوليته المدنيـة طالمـا توافرت أركـان المسؤولية الأخرى من ضـرر وعلاقة

ولــلك فمكمـة الـنقض الفرنسية كانـت حريـصة على عـدم وصـف الخطـأ

بالخطأ الجسيم عندما تتــاول المسؤولية المدنيـة للعامل المضرب، وذلك حتى تـلل على أن الخطـأ الجسيم لـيس شـرطاً لإقامــة المسـؤولية المدنيـة للعامـل المـضرب عن أضرار إضرابه عن العمل، بـالرغم من أن الخطأ فى بعض هذه الأحكام كـان خطاً

(1) Blaise HENRY et Chaumette PATRICK, Chronique de Droit social, en: Revue juridique de l'Ouest, 1989-3, pp. 479-492.

- Maxence VERVOORT, Op.cit, P I 9.

(2) Cass. Soc, 19 décembre 1990, $n^{\circ}$ 89-14576, Bull.civ, $V, n^{\circ} 698$, p. 421, et disponible sur: www.legifrance.gouv.fr.

- Cass. Soc, 23 juin 1988, $n^{\circ}$ 86-12327, et disponible sur: www.legifrance.gouv.fr.

- Cass. Soc, 30 janvier 1991, $n^{\circ}$ 89-17332, Bull.civ, V, $n^{\circ}$ 40, p. 25, et disponible sur: www.legifrance.gouv.fr.

- Cass. Soc, 8 décembre 1983, $n^{\circ}$ 80-14322, Bull.civ, $V, n^{\circ} 602$, et disponible sur: www.legifrance.gouv.fr.

- Cass. Soc, 26 juillet 1984, $n^{\circ}$ 82-14355, Bull.civ, V, $n^{\circ}$ 331, et disponible sur: www.legifrance.gouv.fr.

- Cass. Soc, 30 mai 1989, $n^{\circ}$ 86-16765, Bull.civ, V. $n^{\circ} 405$, p. 244, et disponible sur: www.legifrance.gouv.fr. 


\section{"أمثلة للخطأ البسيم}

ويمكن القول إن خروج العمال عن أي ضـابط من ضوابط الإضراب المنصوص

عليها في قانون العمل المصري يعد خطأ جسيماً، فمثلاً قيام العمال بالإضراب ابل عن العمل

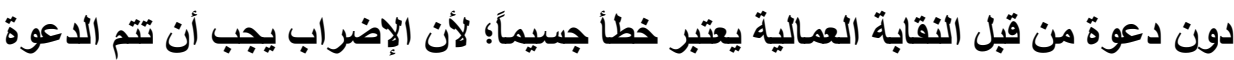

$$
\text { اليه من قبل النقابة حتى يكون إضر اباً مشروعاً. }
$$

كمـا أن أي خروج عن السلمية أثنـاء ممـارسـة الإضـراب يعد خطـأ جسيماً مـن

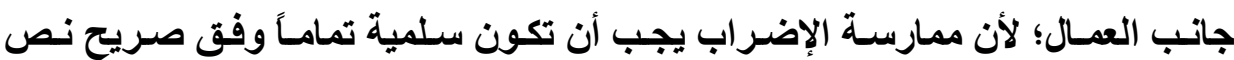

ويعد خطأ جسيماً رفض العمال المضربين عن العمل السماح لسيارات الشركة

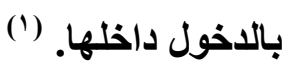

وكذلك يعد خطأ جسيماً منع العمال المضربين العمال غير المضربين من الدخول

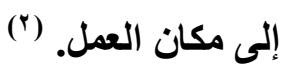

وقد استقرت محكمة النقض الفرنسية أن أي اعتداء ولو كان بسيطاً من قبل

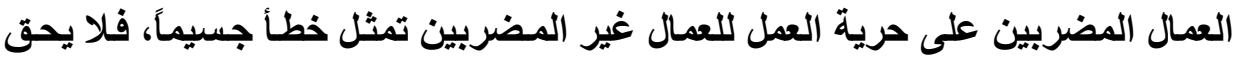

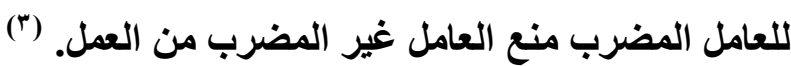

(1) Cass. Soc, 5 décembre 1989, $\mathrm{N}^{\circ}$ de pourvoi: 86-44301, Bull civ, $\mathrm{V}$, $\mathrm{N}^{\circ}$ 693, p. 417, et disponible sur: www.legifrance.gouv.fr.

(2) Cass. Soc, 13 janvier 1993, $\mathrm{N}^{\circ}$ de pourvoi: 90-45760, Bull civ, $\mathrm{V}, \mathrm{N}^{\circ} 7, \mathrm{p}$. 5 , et disponible sur: www.legifrance.gouv.fr.

- Cass. Soc, 17 décembre 2002, $N^{\circ}$ de pourvoi: 00-42115 00- 42136, Bull.civ, $V, N^{\circ} 388, p .384$, et disponible sur: www.legifrance.gouv.fr.

(3) Cass. Soc, 8 octobre 2014, $\mathrm{N}^{\circ}$ de pourvoi: 13-18873,Bull.civ, $V, \mathbf{n}^{\circ} 223$, et disponible sur: www.legifrance.gouv.fr.

$=$ 
بل إن هذا الفعل مجرم في المادة اسب ـ ا من قانون العقوبات الفرنسي، فيعاقب

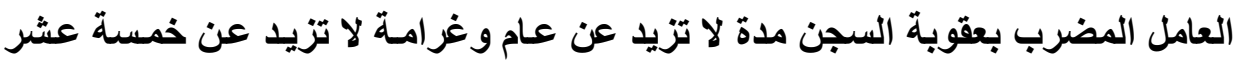
ألف يورو إذا اعتدى العامل المضرب على حرية العمل للعمال الآخرين.

ونفس الأمر فى قانون العقوبـات المصري، حيث جرم القانون الاعتداء على

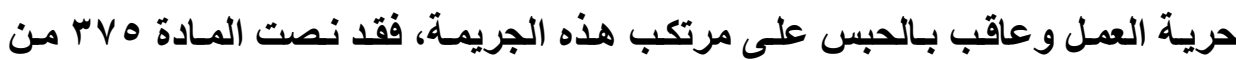
قانون العقوبات على (يعاقب بالحبس مدة لا تجاوز سنتبن ويغرامسة لا تزيـ علـى مائسة

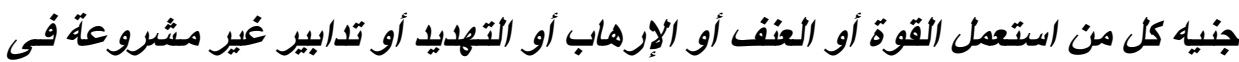

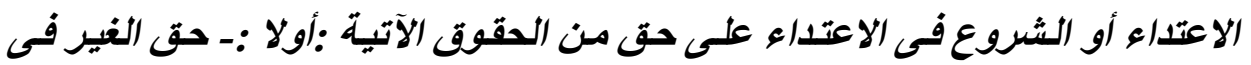

ويُعد خطأ جسيماً المشاركة فى إضراب غير مشروع، فالإضراب إذا (فتقد لأحد

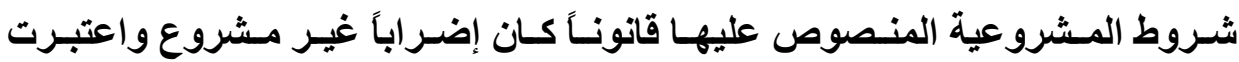

(المشاركة فيه خطأ جسيماً. (1)

فيُعد خطأ جسيماً الاشتر اك في إضـراب داخل مكـان العمـل للمطالبـة بمطالب

(ن) سياسية وليس المطالبة بمطالب مهنية.

- Cass. Soc, 10 février 2009, $N^{\circ}$ de pourvoi: 07-43939, Non publié au bulletin, disponible sur: www.legifrance.gouv.fr.

- Cass. Soc, 14 mai 2008, $N^{\circ}$ de pourvoi: 06-46095, Non publié au bulletin, disponible sur: www.legifrance.gouv.fr.

- Cass. Soc, 15 mai 2001, $N^{\circ}$ de pourvoi: 00-42200, Bull civ, $\mathrm{V}, \mathrm{N}^{\circ} 166$, $\mathrm{p}$. 131, et disponible sur: www.legifrance.gouv.fr.

- Cass. Soc, 5 juillet 1995, $\mathrm{N}^{\circ}$ de pourvoi: 93-46108, Non publié au bulletin, disponible sur: www.legifrance.gouv.fr.

(1) Cass. Soc, 25 juin $1987, N^{\circ}$ de pourvoi: 85-40250, Bull V, $N^{\circ} 420$, p. 266, et disponible sur: www.legifrance.gouv.fr.

(2) Cass. Soc, 23 mars 1953, $N^{\circ}$ de pourvoi: 53-01398, Bull.soc, $N^{\circ} 253, P$. 188 , et disponible sur: www.legifrance.gouv.fr

$=$ 
ومن الأخطاء الجسيمة التي يمكن أن يرتكبها العمال المضربون احتجـاز أفراد

داخل مكان العمل ومنعهم من الخروج منه مثل احتجاز عملاء المنشأة أو احتجاز العمال

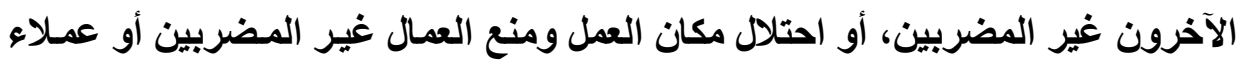

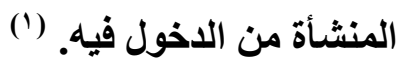

وهذا الاحتجاز للأثخاص يعد جريمه جنائية وفقا لنص المادة ؟ Y Y / من قانون

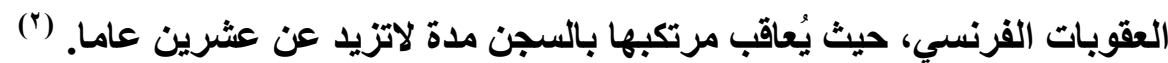

- Cass. Soc, 10 mars 1961, Bull.soc, $N^{\circ}$ 333, et disponible sur: www.legifrance.gouv.fr.

- Cass. Soc, 1 mars 1961, Bull.soc, $N^{\circ}$ 270, et disponible sur: www.legifrance.gouv.fr.

- Cass. Soc, 5 octobre 1960, Bull.soc, $N^{\circ}$ 818, et disponible sur: www.legifrance.gouv.fr.

- Cass. Soc, 29 janvier 1960, Bull.soc, $N^{\circ}$ 113, et disponible sur: www.legifrance.gouv.fr.

(1) Mathilde CARON, Grève dans le privé, Op.cit.

- Cass. Soc, 2 juillet 2014, $N^{\circ}$ de pourvoi: 13-12562, Bull.civ, $V, n^{\circ} 158$, et disponible sur: www.legifrance.gouv.fr

- Cass. Soc, 10 mars 1961, Bull.soc, $N^{\circ}$ 333, et disponible sur: www.legifrance.gouv.fr.

- Cass. Soc, 1 mars 1961, Bull.soc, $N^{\circ}$ 270, et disponible sur: www.legifrance.gouv.fr.

- Cass. Soc, 5 octobre 1960, Bull.soc, $N^{\circ}$ 818, et disponible sur: www.legifrance.gouv.fr.

- Cass. Soc, 29 janvier 1960, Bull.soc, $N^{\circ} 113$, et disponible sur: www.legifrance.gouv.fr.

(r) لمزيد من التفاصيل عن المسؤولية الجنائية للعامل عن ممارسة الحق فى الإضراب، انظر:

Maxime BAILLY, Essai sur le droit penal des conflits collectifs du travail, Thèse, Fac de Droit et de Science Politique d'Aix-Marseille,

UNIV PAUL CEZANNE - AIX-MARSEILLE III, 2011. 
وبقاء العمال المضربين في مكان العمل بعد قيام رب العمل بإصدار أوامره لهم

بعدم التواجد في مكان العمل أثناء الإضراب يعد خطأ جسيماً. (1)

أما قيام العمال المضربين بـاحتلال رمزى لمكان العمل دون التعدى على حريـة

العمال الآخرين فى العمل أو منعهم من العمل يعد خطأ غير جسيم. (r)

ويعد خطأ جسيماً قيام العمال بالإضراب دون إخطار رب العمل بالمطالب المهنية

التي يضريون من أجلها. (r)

وهناك كثير من صور الخطأ الأخرى التي من الممكن ارتكابها من قبل العمـال

أثناء الإضراب مثل الاعتداء على صاحب العمل أو الاعتداء على العمال غير المضربين

أو إتلاف أدوات العمل. (؛)

فوفقاً للمـادة الهـ/أ مكرر مـن قـانون العقوبـات المصري، فـإن كل مـن يعطل وسيلة من وسائل الإنتاج يُعاقب بعقوبة السجن.

(1) Cass. Soc, 30 avril 1987, $N^{\circ}$ de pourvoi: 84-41871 84-41873 84-42370, Bull civ, $V, N^{\circ} 238, p .152$, et disponible sur: www.legifrance.gouv.fr.

- Cass. Soc, 1 février 1978, $N^{\circ}$ de pourvoi: 76-40273, Bull. soc, $n^{\circ} 73$, P. 53, et disponible sur: www.legifrance.gouv.fr.

(2) Cass. Soc, 25 juin $1987, \mathrm{~N}^{\circ}$ de pourvoi: 85-40250, Bull civ , $\mathrm{V}, \mathrm{N}^{\circ} 420$, p. 266, et disponible sur: www.legifrance.gouv.fr.

(3) Cass. Soc, 30 juin 2015, $\mathrm{N}^{\circ}$ de pourvoi: 14-11077, disponible sur: www.legifrance.gouv.fr.

(4) Pauline DISDIER, Op.cit. 
ومن ناحية أخرى فقد يكون الإضراب فى ذاتـه مشروعاً والمطالب مشروعه، ويرتكب العــال أخطـاء أثنـاء ممارسـة هـا الإضـراب، في هـذه الحالـة يكـون العــال مسؤولين عن هذه الأخطاء دون أن يؤدى ذلك لوصف الإضراب بعدم المشروعية. ويقع على عاتق قاضى الموضوع تقدير مدى وجود خطأ من عدمه وذلك بالنظر في مشروعية الإضراب ذاته، فبإذا تخلف فيه أي شرط مـن شروط المشروعية كـان إضراباً غير مشروع وتكون المشاركة فيه خطأ. أما إذا توافرت كل شروط المشروعية كـان الإضراب مشروعاً، ولكن قد يكون

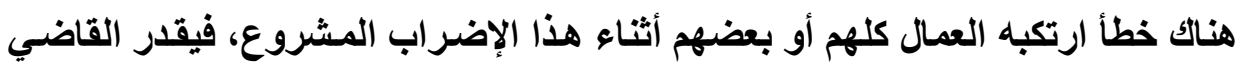
مدى وجود هذا الخطأ المصاحب للممارسة المشروعة للإضراب.

\section{الفرع الثاني}

\section{الضرر}

أثثير التساؤل عن الضرر المترتب عن ارتكـاب العمال المضربين لخطأ الاعتداء على حرية العمل للعمال غير المضربين بمنعهم من القيام بالعمل، فهل الضرر يصيب العمال غير المضربين، أم أن الضرر يصيب رب العدل؛ لأنها ملتزم بـفع أجور العمـال غير المضربين رغم عدم قيامهم بالعمل؟

فمكمة النقض الفرنسية (الدائرة الجنائية) قد قضت بأن الضرر المترتب على جريمة العمال المضربين في الاعتداء على حريـة العمل للعمـال غير المضربين ينقسم إلى ضرر مباشر وضرر غير مباشر، فالضرر المباشر هو الضرر الذى يصيب العمال

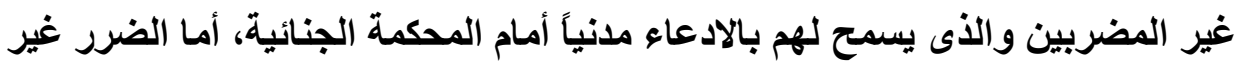
المباثر فهو الضرر الذى يصيب رب العمل في الخسارة التي تصيبه نتيجة دفع رواتب 
العمال غير المضربين رغم عدم قيامهم بالعمل، وهو ما لا يسمح له بالادعاء مدنياً أمسام

(1) المحكمة الجنائية.

إلا إن الدائرة الاجتماعية لمحكمة النقض الفرنسية أيدت الحكم بـالتعويض على املى

أحـد العــال المضربين الذى اعتدى على حريـة العمل لبـاقى العمـال غير المضربين

ومنعهم من دخول مكان العمل، فقد أيدت المحكمة الحكم عليه بتعويض رب العمل عن

أجور العمال في هذا اليوم. (r)

ونرى مع رأى في الفقهـ الفرنسي أن الاختلاف بين الدائرة الجنائية والـدائرة

الاجتماعيـة لمحكمـة النقض الفرنسية هو اختلاف إجرائسي وليس موضـوعى، فهنـاك

ضرر أصـاب رب العمل ـمن جريمـة العمـال المضربين فى الاعتـاء على حريـة العمل العل

للعمال غير المضربين- لا يحق لـه أن يدعى بهذا الضرر مدنياً أمسام المحكمة الجنائية

التي تنظر الدعوى الجنائية، ولكن يحق لـه رفع دعوى مدنية أصلية أمسام المحكمـة

المدنية للمطالبة بتعويض هذا الضرر. (r)

(1) Cass. crim, 15 mai 1987, $\mathrm{N}^{\circ}$ de pourvoi: 86-91015, Bull. crim 1987, $\mathrm{N}^{\circ}$ 198, p. 533, et disponible sur: www.legifrance.gouv.fr.

- Cass. crim, 27 novembre 1979, $N^{\circ}$ de pourvoi: 78-93150, Bull. crim 1987, $N^{\circ} 339$, et disponible sur: www.legifrance.gouv.fr.

(2) Cass. Soc, 8 février 1972, $N^{\circ}$ de pourvoi: 71-40285, Bull.Soc, $N^{\circ} 113, P$. 105, et disponible sur: www.legifrance.gouv.fr.

(3) Jean SAVATIER, L'irrecevabilité de l'action civile exercée par l'employeur devant les tribunaux répressifs pour entrave à la liberté du travail, D.S, 1981, P.148. 
ومن الأضرار المباشرة التي يمكن أن تصيب رب العمل هو تلف آلات المصنع

نتيجة لتحطيم العمال المضربين لهذه الآلات وتخريبها. (1) وكذلك فإن قيام العمال المضربين بالاعتداء على العمال غير المضربين قد يؤدى إلسى إصـابتهم بأضــرار جسمانية أو أضـرار أدبيـة، وكــلك الحسال إذا اعتـدى العمـال المضريون على عملاء منشأة رب العمل، فقد يصيبهم ذلك بأضرار مادية أو أدبية. الفرع الثالثث

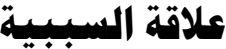

الأصل في القواعد العامـة للمسؤولية المدنية أنهـ يجب إثبـات ارتكاب المدعى عليه للخطأ حتى يمكن إسناد المسؤولية المدنية لـه، فلا يكفى إثبات أن المدعى عليه كان عضوا في المجموعة المرتكبة للخطأ حتى يمكن إسناد الخطأ إليه. (†) وبتطبيق هذه القاعدة على الأخطـاء المرتكبة أثنـاء الإضراب، فبإن المضرور يجب أن يثبت إرتكاب كل عامل مدعى عليه للخطأ الذي سبب الضرر لله والذى ارتكب أثـــاء ممارســة الإضـراب، ولا يكفـى أن يثبـت اشـتراك العامـل فـي الإضــراب غيـر

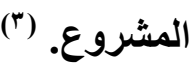

ولكن تطبيق هذه القاعدة على الإضراب غير المشروع سيؤدى إلى صعوبة

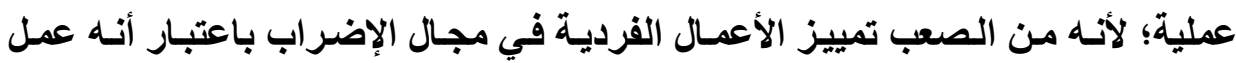

(1) Pauline DISDIER, Op.cit.

(2) Birame DIOUF, Op.cit, P 230.

(3) Pauline DISDIER, Op.cit. 
جماعى، لذلك سيكون من الصعب على المضرور إثبات علاقة السببية ببين خطأ كل عامل والضرر الأى أصابه. (1)

إلا إنه بالرجوع إلى أحكام محكمة النقض الفرنسية نجد أنها صـارمة في تطلب

إثبات علاقة السبيية بين خطأ كل عامل مشـارك في الإضراب والضرر الذى أصساب

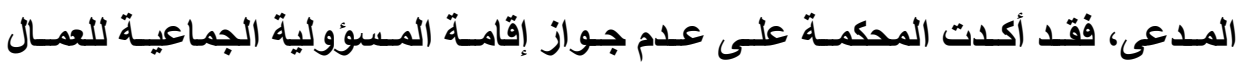

المسشاركين في الإضـراب، وأن المـضرور يجب أن يثبت الـدور الإيجـابي في الخطـأ

المسبب للضرر لكل شخص من المدعى عليهم، ولا يكتفى بإثبات اشتراك المدعى عليه

في الإضراب غير المشروع. (ץ)

(1) Birame DIOUF, Op.cit, P 231.

- Maxence VERVOORT, Op.cit, P 130.

(2) Cass. Soc, 18 janvier 2017, $\mathrm{N}^{\circ}$ de pourvoi: 15-22428 15-22430 15-22431 15-22432 15-22433 15-22434 $15-22435 \quad 15-22436 \quad 15-22437$ 15-22438, Non publié au bulletin, disponible sur: www.legifrance.gouv.fr.

- Cass. Soc, 18 septembre 2007, $N^{\circ}$ de pourvoi: 06-41761, Non publié au bulletin, disponible sur: www.legifrance.gouv.fr.

- Cass. Soc, 15 mai 2001, $N^{\circ}$ de pourvoi: 00-42200, Bull.Civ, V, No 166, p. 131, et disponible sur: www.legifrance.gouv.fr.

- Cass. Soc, 4 novembre 1992, $\mathrm{N}^{\circ}$ de pourvoi: 90-41899, Bull.civ, $\mathrm{V}, \mathrm{N}^{\circ}$ 529, p. 335, et disponible sur: www.legifrance.gouv.fr.

- Cass. Soc, 18 janvier 1995, $\mathbf{N}^{\circ}$ de pourvoi: 91-10476, Bull.Civ, V, No 27, p. 18 , et disponible sur: www.legifrance.gouv.fr.

- Cass. Soc, 9 mars 1989, $N^{\circ}$ de pourvoi: 87-40131, Bull.civ, V, $N^{\circ} 196$, p. 116, et disponible sur: www.legifrance.gouv.fr.

- Cass. Soc, 30 janvier 1991, $\mathrm{N}^{\circ}$ de pourvoi: 89-17332, Bull.civ, V, $\mathbf{N}^{\circ} 40$, p. 25, et disponible sur: www.legifrance.gouv.fr.

- Cass. Soc, 31 mars 1998, $N^{\circ}$ de pourvoi: 95-42086, Bull.civ, V, $N^{\circ} 180$, p. 131, disponible sur: www.legifrance.gouv.fr.

$=$ 
فقضاء محكمة النقض يدل على أن المسؤولية المدنية عن الأخطاء المرتكبة أثناء الإضراب هي مسؤولية شخصية رغم أن الإضراب هو بطبعه عمل جماعى. ويستطيع المضرور أن يثبت خطأ العامل المضرب عن العمل والضرر المترتب عليه وعلاقة السببية بينهما بجميع طرق الإثبات بما فى ذلك شهادة الثهود؛ وذلك لأن هذه وقائع مادية.

فيستطيع رب العملـمثلا- أن يثبت أن الخطأ الذى ارتكبه المضربون في احتلال مكـان العـل هو الذّى أدى إلى تعطل العـل خـلال سـاعات الإضـراب وحدوث الضرر المتمثل في الخسائر التي منى بها نتيجة تعطل العمل هذه الساعات وعدم قدرة العمـال

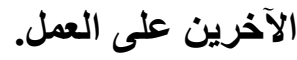
فقد أيدت محكمة النقض الحكم برفض طلب رب العمل بـإلزام العمـال المضربين بدفع تعويض له نتيجة قيامهم باحتلال مكان العمل مما منع العمـال غير المضربين من العمل؛ وذلك لأن المحكمـة وجدت أنسه على الرغم من ارتكاب خطأ مـن جاتب العمـال المضربين في احتلال مكان العمل، إلا إن ذلك لم يمنع العمال غير المضربين من العمل، وبالتالي تنتفى علاقة السببية بين خطأ العمال المضربين والضرر الذى يدعيـه رب

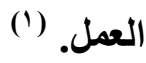

فمثلا إذا تسبب الإضراب الى شلل تـام في المنشأة ممـا يستحيل معه قيام بـاقى العمال بالعمل؛ لأن العمال المضربين في أقسام محوريـة داخل المنشأة، فإن عدم قدرة

- Cass. soc, 19 déc 1990, $\mathrm{N}^{\circ}$ de pourvoi: 89-14576: Bull. Civ, V, № 698, p. 421, et disponible sur: www.legifrance.gouv.fr.

(1) Cass. Soc, 19 octobre 1994, $\mathrm{N}^{\circ}$ de pourvoi: 92-11795, Non publié au bulletin, disponible sur: www.legifrance.gouv.fr. 
العمال غير المضربين عن العمل يكون ناتجاً عن الإضراب نفسه ولا يمكن أن ينتج عن خطأ العمال المضربين في منع العمال غير المضربين من الاخول إلى مكان العمل؛ لأنـه حتى لو لم يتم منعهم من الاخول فلن يستطيعوا القيام بالعمل. ومن ناحية أخرى فيجب أن نوضح أن العامل مسؤول فقط عن الضرر المترتب مباشـرة عن الخطأ الذي ارتكبه،، ولا يكون مسؤولاً عن الضرر المترتب عن خطـأ النقابة، إلا إذا اجتمع خطأ النقابة مع خطأ العامل وكان خطأ النقابة بسيطاً جداً بالنسبة الندان لخطأ العامل الجسيم، فهنا يستغرق خطأ العامل خطأ النقابـة ويُسأل العامل عن الضرر كله

\section{الإطلب الثالث \\ أثر المسؤولية}

إذا توافرت عناصر المسؤولية مسن خطأ وضرر وعلاقة سببية بينهما، فتقام مسؤولية العمال الذين ارتكبوا الخطأ أثناء ممارسة الحق في الإضراب دون تفرقة في

إقامة المسؤولية بين العامل الذى يكون له دور نقابى والعامل العادى الذى لا يلعب أي دور.

فقد أيدت محكمة النقض الفرنسية الحكم بالتعويض على أحد العمـال المشاركين في إضراب للمطالبة بأهداف سياسية؛ لأن المشاركة في الإضراب لأهداف سياسية هو

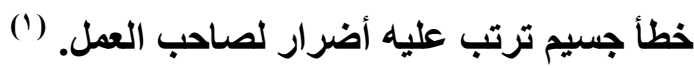

(1) Cass. Soc, 23 mars 1953, $\mathrm{N}^{\circ}$ de pourvoi: 53-01398, Bull.Soc, N. 253, P. 188 , et disponible sur: www.legifrance.gouv.fr. 
والمهم هنا هو التاكيد على أن التعويض يكون عن الضرر المترتب عن الخطأ في ممارسة الحق في الإضراب، أما أي أضرار أخرى فلا يُسأل عنها العامـل المضرب،

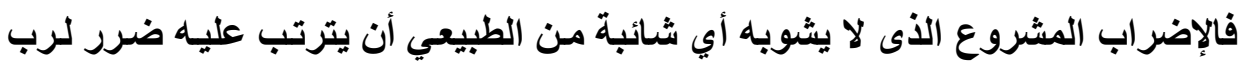
العمل، وبالتالي يجب على القاضي أن يحكم بالتعويض بالقدر الأي يجبر الأضرار التي يثبـ المسدعى علاقة السبيية بينها وبين الخطأ في ممارسـة الإضـراب، أمسا الضرر المترتب عن الإضراب نفسه فلا تعويض عنه. (1) وفى الواقع فإن مهمة القاضى تكون صعبة فى هذه الحالةة؛ لأن عليه أن يقوم بالتمبيز بين الأضرار المقبولة وغير المقبولة، ويقدر قيمة التعويض الأى يجبر الضرر غير المقبول دون الضرر المقبول. (广)

فقد أيلت محكمة النقض الفرنسية الحكم على سبعة عمـال مضربين بتعويض خمسة وثلاثين عاملاً غير مضرب بدفع أجورهم التى يرفض رب العمل دفعها؛ وذلك لأن العمال المضربين قاموا بـاغلاق أبواب المنشأة بالسلاسل الحديدية ومنعوا العمـال

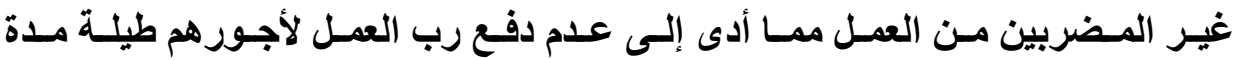

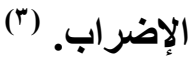

ويلاحظ هنا أن الحكم بالتعويض على مجموعه من العمـال لارتكـابهم خطأ أثنـاء ممارسة الإضراب يؤدى إلى تضامنهم فى الوفاء بمبلغ التعويض للمضرور، بحيث يحق

(1) Birame DIOUF, Op.cit, $P$ ror.

(2) Maxence VERVOORT,Op.cit, $P$ Ir'.

(3) Cass. Soc, 6 juin 1989, $N^{\circ}$ de pourvoi: 87-40738, Bull.Civ, V, $\mathrm{N}^{\circ} 425$, p. 257, et disponible sur: www.legifrance.gouv.fr. 
للمضرور الرجوع على أي منهم لاقتضاء مبلغ التعويض كاملاً، ثم يكون من حق العامل

الاى دفع المبلغ كاملاً أن يرجع على بقية العمال بنصيب كل منهم. (')

وإذا حكم القاضى على العمال بتعويض المضرور من الإضراب، فإن ذلك يمثل إرهاقا للعمال لأنهم فى الغالب يكونـون غير قادرين على القيام بدفع هذه التعويضات كلها، حيث إنها فى الغالب تكون باهظة، للألك يرى البعض بأنه يقتضى من المشرع التدخل لوضع حد أقصى للتعويض الذي يحكم بـه القاضى على العامـل فى حالة جبر الـضرر المترتب عن الإضـراب. فهـا الـرأى يـرى بـأن تطبيق القواعد العامـة فى في المسؤولية التقصيرية فى مجال التعويض عن الإضراب سوف يمثل عبئَاً ثقيلاً على العمال مما يؤدى إلى تقييد ممارسة العمال لحقهم الدستورى فى الإضراب.(؟) ولا نؤيد هذا الرأي، لأن وضع حد أقصى للتعويض فيه ظلم للمضرور، ويؤدى لعدم مسؤولية العامل عن جزء من الخطأ الذى ارتكبه، وهو ما يتعارض مع ما سبث أن حكم بـه المجلس الاسـتورى الفرنسـي بعدم دسـتورية أي نـص تشريعي يقرر عدم المسؤولية عن خطأ معين.

كما أن العامل يستطيع أن يتجنب الحكم عليه بالتعويض إن هو امتثل للضوابط التي نص عليها القـانون وامتثل لأوامر النقابـة الداعيـة للإضراب والمنظمـة لـه؛ لأن المسؤولية ستقع على عاتق النقابـة في هذه الحالة إذا هي ارتكبت خطأ في الدعوة ل للإضر اب أو تنظيمه.

(1) Cass. Soc, 8 décembre 1983, $N^{\circ}$ de pourvoi: 81-14238, Bull. Soc, $\mathrm{N}^{\circ} 598$, et disponible sur: www.legifrance.gouv.fr.

(2) Maxence VERVOORT, Op.cit, P r \& \&. 


\section{المبحث الثاني \\ تصسف العاهل فى همارسة الإضراب}

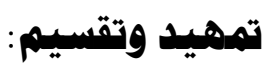

قد يمتثل العامل للضوابط التي قررها القانون لممارسة حق الإضراب، وفى هذه

الحالة تكون ممارسة حق الإضراب ممارسة مشروعة، إلا إنه رغم ذلك قد يترتب على التى

هذه الممارسة المشروعة أضرارٌ تصيب الغير نتيجة وجود بعض التعسف في فمي ممارسـة

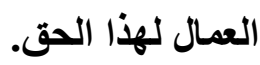

وفي هذا السياق أكدت محكمة العدل الأوروبية على أن الحق في الإضراب هو

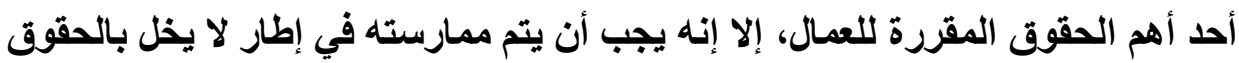

والحريات الأخرى مثثل حرية تقديم الخدمات. (1)

ولذلك رأي بعض الققه أن الحق في الإضراب بمقتضى هذا الحكم يـخل في

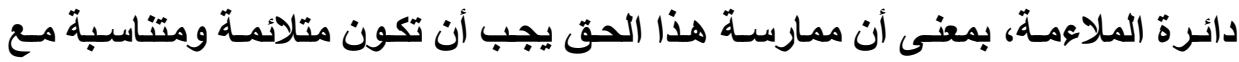

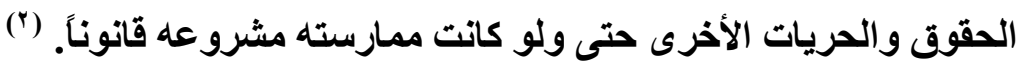

(1) CJCE (Gde Ch.), 18 décembre 2007, Laval un Partneri Ltd, C-341/05, disponible sur:

http://ec.europa.eu/dgs/legal_service/arrets/listepartheme_fr.htm.

(2) Joël CAVALLINI, Une action collective licite en droit interne peut être contraire à la liberté d'établissement consacrée par le traité de Rome, JCP S, 5 Février 2008 - $n^{\circ} 6$. 
فبمقتضى هذا الحكم يكون من الواجب على العمـال بحث مدى ملاعمـة ممارسـة الحق في الإضراب قبل الثروع فيه أو مدى ملاءمة الاستمرار في الإضراب بعد البداء

ولذلك قرر المجلس الدستورى الفرنسي منذ وقت بعيد أن إقرار الاستور للحق

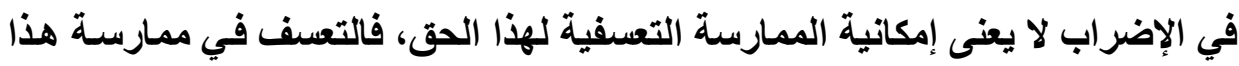

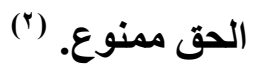

فبالرغم من أن الحق في الإضراب هو حق دستورى، إلا أنسه من الممكن أن

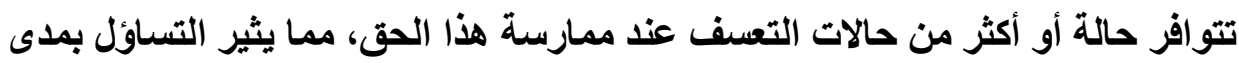

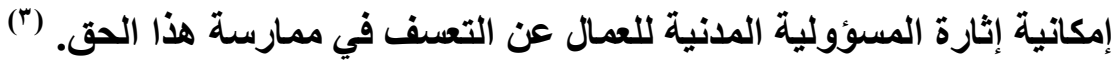
فرب العمل لا يحق لهه أن يوقع جزاءً تأديبياً على العامل في حالة الممارسـة المشروعه للحق في الإضراب، ولكن من المككن أن نتساعل عن مدى حق رب العمل

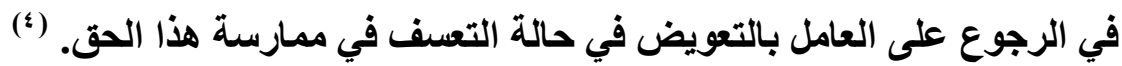
والواقع أن التمييز بين الممارسـة المشروعة التعسفية والممارسة المشروعة غير التعفية هو من الأمور الدقيقة جداً خاصة في نطاق ممارسة حق دستورى مثل الثئل

$$
\text { الحق في الإضراب. }
$$

(1) Jean-Pierre Marguénaud et Jean Mouly, La Cour européenne des droits de l'homme à la conquête du droit de grève, RDT, 2009, P 499.

(2) CC, décision $\mathrm{n}^{\circ} 01645,7$ juillet $1950, \mathrm{RCC}, \mathrm{p} .426$, et disponible sur : www.conseil-constitutionnel.fr

(3) Cathy NEUBAUER, Op.cit.

(4) Adrien LANCIAUX, Op.cit. 
فهل من الممكن الحكم على العامل بتعويض الأضرار المترتبة على إضرابه عن

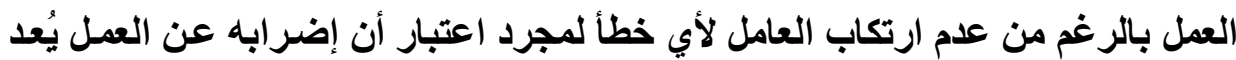

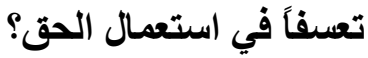

مما لاشك فيهـ أن الإجابـة على هذا التساؤل تختلف في القانون الفرنسي عن

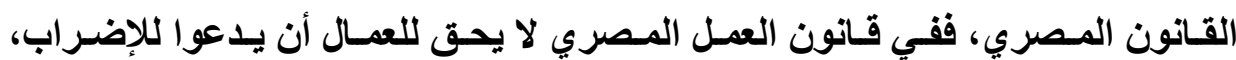

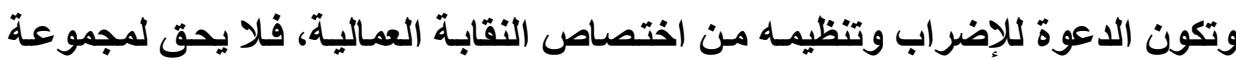

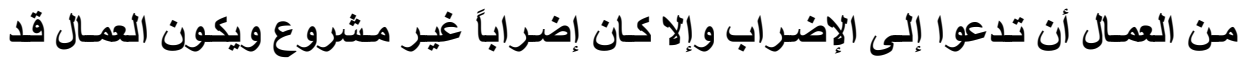
ارتكبوا خطأ تقصيريًً بممارستهم لهذا الإضراب، وبالتالي فلا يمكن أن نتسب للعمسال التعسف في استعمال حق الإضراب، وقد يُنسب التعسف للتقابـة العماليـةكمـا رأينـا

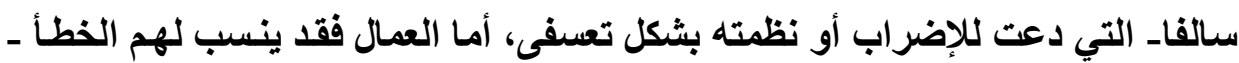

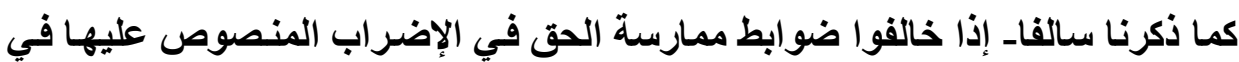

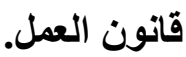

ويختلف الأمر بالنسبة للقانون الفرنسي، حيث يحق لمجموعة من العمالـ في

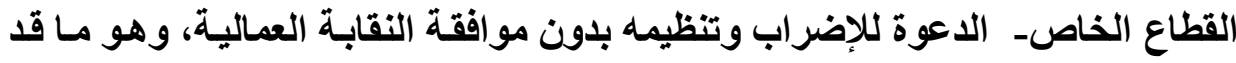

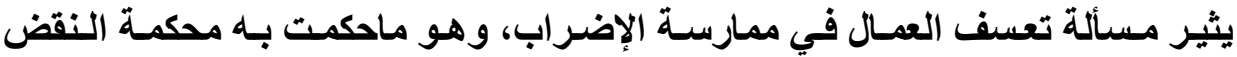
الفرنسية في كثير من الأحيان كما سنرى لاحقًا.

سنقوم في هذا المبحث باراسة حالات التعف في استعمال الحق ومدى إمكانية تطبيقها على الأضرار المترتبة على الممارسة المشروعة للحق في الإضراب من قبل

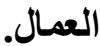
وحتى نتناول هذه المسألة، فسوف نقوم بتقسيم هذا المبحث إلى: المطلب الأول: حالات التعسف فى ممارسة الحق فى الإضراب. المطلب الثاني: أثر التعسف. 


\section{المطلب الأول}

\section{حالات التعسف فى مهارسة الحق فى الإضراب}

يجوز تقييد الحق في الإضراب إذا كانت ممارسة هذا الحق تمثل تعسفاً، أي أن

الممارسة التعسفية للحق في الإضراب محظورة حتى ولو كانت هذه الممارسـة لا تعتبر خطأ، فالتعسف في استعمال الحق هو أحد القيود التي يجب أن يتقيد بها الحق في

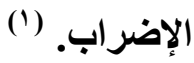

ولكن تظل هناك مشكله فى تحديد الحالات التى يعتبر فيها العامل المضرب عن

العمل متعفاً فى ممارسته لهذا الحق بالرغم من أنه لم يرتكب خطأ.

تطبيقًا للقواعد العامة في القانون المدني، فِان العامـل يعد متعسفاً في استعمال

حق الإضراب إذا قصد الإضرار بالغير، أو كانت المصالح التي يرمسي الى تحقيقها غير مشروعة، أو كان الضرر المترتب على ممارسـة هذا الحق تفوق المصلحة المترتبـة عليه.

\section{أولاًا تصد الإضرار بالغير:}

إذا كان قصد إحداث الضرر بـالغير هو العامل الأصلـي الذي غلب عند صـاحب

الحق وهو يستعمل حقه، اعتبر هذا تعسفاً، ولو كـان هذا القصد مصحوباً بنية جلب

المنفعة كعامل ثانوي، سواء تحققت هذه المنفعة أو لم تتحقى، ويكون تعسفاً ــ من بـاب

(1) Nicolas MOLFESSIS, Le Conseil constitutionnel et le droit privé, Ed L.G.D.J, 1998, p. 135. 
أولى- قصد إحداث الضرر غير المقترن بنية جلب المنفعة حتى لو تحققت هذه المنفعة عن طريق عرضي. (1) فإذا توافرت لدى العـال المضربين النية الواضحة للإضرار برب العدل، فبان الإضراب يكون تعسفيا، بشرط أن يكون الإضرار برب العمل هو الهـف الوحيد من

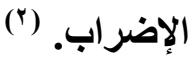
فقد اعتبرت محكمـة النقض الفرنسية أن العــال المضربين قد تعسفوا فى

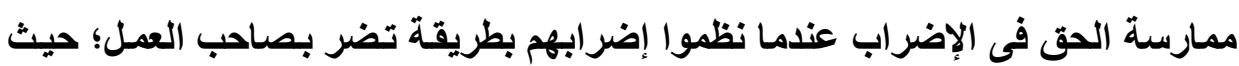
اتفقوا على انسحاب بعض العمـال المؤثرين فى كل قسم بحيث يتبقى مجموعة مـن العمال لا تستطيع العمل ممـا يؤدى للتوقف التـام للمنشأة، وفى ذات الوقت التزام رب

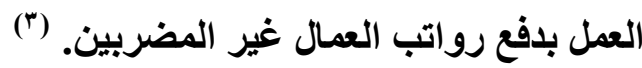
وقد يكون الإضراب تعسفياً إذا كانت ظروفه غير مواتية، أو تكرر في أوقات زمنية قصيرة دون ترك فرصـة لصاحب العمل للاستجابة لطلبـات الإضراب ممـا يتبين منه نية العمال للإضرار بصاحب العل. فقد ذكرنـا سـابقاً أن محكمـة النقض الفرنسية قد أقرت بمشروعية الإضـراب المتتابع، أي أن الإضراب لا يكون في كل مكـان العمل في آن واحد، وإنمـا يحدد وقت معين لكل قسم من أقسام العمل ليقوم بالإضراب بحيث ينتهى الإضراب في قسم ليبدأ في

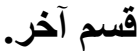

(1) السنهورى، الوسيط، مصادر الإلتزام، مرجع سابق، صـ 90V، فقرة ـ ؟4.

(2) Maxence VERVOORT, Op.cit, P I Y o.

(3) Cass. Soc, 11 juin 1981, $\mathrm{N}^{\circ}$ de pourvoi: 79-42013 79-42023, Bull.civ, $N$. 522, Et disponible sur: www.legifrance.gouv.fr 
فبالرغم من مشروعية هذا الإضراب إلا أن هنـاك رأي في الفقهـ الفرنسي يري بأن هذا الإضراب هو إضراب تعسفى مخـالف لمقتضيات حسن النية؛ وذلك لأن هذا الإضر اب يكون مدبر من قبل العمال للإضرار بصاحب العمل، فتوقف كل قسم من أقسام المنشأة عن العمل لمدة محددة يترتب عليه في الواقع عدم تقديم عمل مفيد في ذلك اليوم وحدوث إضطراب في المنشأة، في حين أن رب العدل ملزم بـدفع أجور العمـال كاملة عن هذا اليوم مع خصم جزع ضئيل جداً مساوى للوقت القليل المحدد للإضراب مما يسبب خسارة لرب العمل. (1) ومن ناحية أخرى فقد أقرت محكمة النقض الفرنسية بمشروعية الإضراب في قسم واحد فقط من أقسام المنشأة وهو القسم الرئيسي الذى يترتب علي توقفه توقف كل

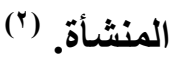
ولكنَّ جاتباً من الفقه الفرنسي يرى أن هذا الإضراب هو إضراب تعسفى؛ وذلك لأن العمـال بالمنششأة يتفقون على إضـراب عمـال هـا القسم فقط دون بقيـة العمـال، ويهدفون من ذلك إلى توقف المنشأة كلها، وفى ذات الوقت يلتزم رب العمل بدفع أجور العمال غير المضربين في كل الأقسام الباقية في كل أيام الإضراب بالرغم من أن هؤلاء العمال في الحقيقة لن يعملوا لتوقف القسم الرئيسي بالمنشأة.

(1) Roger LATOURNERIE, Op.cit, P 434.

(2) Cass. Soc, 15 janvier 1964, Bull.Civ. $N^{\circ} 47$, et disponible sur: www.legifrance.gouv.fr.

- Cass. Soc. 19 octobre 1994, $N^{\circ}$ de pourvoi: 91-20292, Bull.Civ. V, $N^{\circ} 281$ p. 190, et disponible sur: www.legifrance.gouv.fr.

(3) Birame DIOUF, Op.cit, P 225. 
فإضر اب عمـال قسم واحد فقط مـن اقسام المنشاة وهو القسم الرئيسي فيها والمحورى يُعد إضـرابًا مشروعاً، إلا أنـه قد يعد إضراباً تعسفيًَّ إذا ترتب عليهه عدم

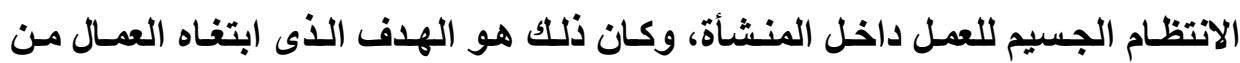
الإضراب، فيكونون قد قصدوا الإضرار برب العمل. (1) ثانيساً رجمان الضرر على المصلمة رجمانًا كبيراً: المعيار هنا موضوعي وهو معيار السلوك المألوف للثخص العادي، فليس من المألوف للشخص العادي أن يستعمل حقاً على وجه يضر بالغير ضرراً بليفاً، ولا يكون له في ذلك إلا مصلحة قليلة الأهمية لا تتناسب البتة مـع هذا الضرر، فيكون استعمال

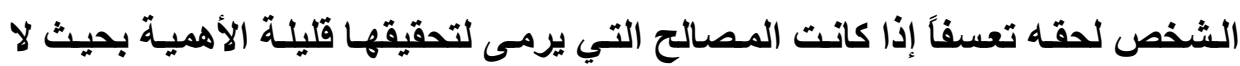
تنتاسب البتة مع ما يصيب الغير من ضرر بسبيها. (r) ومن أمثلة الإضراب الذي يترتب عليه أضرارٌ كبيرة قد تفوق المصلحة المترتبة

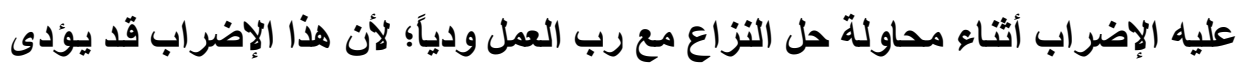
إلى فثل العلول الودية للنزاع وهو ما يُعد ضرراً كبيراً لصاحب العمل. فقد نصت المـادة (L2522-2) من قانون العمل الفرنسي على أنسه يجب على أطراف المنازعـة العماليـة أن يقدموا كل التسهيلات الممكنة للوسطاء الذين يقومـون بمحاولة حل النزاع حتى تنجح مهمتهم.

(1) Mathilde CARON, Grève dans le privé, Op.cit.

- Cass. crim, 20 avril 1982, Non publié au bulletin, disponible sur: www.legifrance.gouv.fr

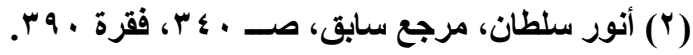


فهذا النص قد وضع التزامساً بحسن النية على عاتق أطراف النزاع من عمـال

ورب عمل بعدم وضع أية عراقيل أمام مهمة الوسيط الذى يحاول حل النزاع العمالى.

وهذا الالتزام يقتضى من طرفى النزاع التعاون مع الوسيطوتقديم كل المعلومات والمستندات التي تفيده في حل النزاع القائم وعدم القيام بأي أمر من شـأنه إفشـال هذه

(1) (لمهمة.

ولذلك فقد قررت محكمة النقض الفرنسية أن التظاهر بالتفاوض مع الوسيط من قبل أحد طرفى النزاع العمالى مع الإصرار على عدم الوصول لحل لهذا النزاع يتعارض مـع مبـأ حسن النية الذى يجب أن يتحلى بـه أطراف النزاع أثنـاء محاولـة التسوية (ن) الودية له مبله

فليس مـن الملائسم اللجوء للإضـراب أثنـاء محاولـة التسوية الوديـة لمنازعـات العمل الجماعية سـواء بطريـق الوسـاطة أو بطريـق التحكيم، حتى لا يُفشل الإضراب المحاولات الوديـة لتسوية النزاع، وقد يوصف هذا الإضراب بالتعسفى إذا كـان مـن الممكن أن يؤدي إلى فشل المحاولات الوديـة لتسوية النزاع؛ لأن ذلكك قد يُعتبر ضرراً يفوق المصلحة المبتغاة من الإضراب. (َ) ومـن ناحيـة أخرى فقــ اعتبرت محكمـة النقض الفرنسية أن قيـام المـضربين بتظيم الإضراب في صورة إضرابات متقطعة ومتكررة وقصيرة نوع من أنواع التعف في استعمال حق الإضراب؛ لأن العمال يقومون بالعمل سـاعة والإضراب سـاعة أخري

(1) Birame DIOUF, Op.cit, $P$ q V.

(2) Cass. Soc. 20 février 1991, $N^{\circ}$ de pourvoi: 87-41016, Bull. civ, $V, n^{\circ} 89$, p. 54. disponible sur: www.legifrance.gouv.fr.

(3) Birame DIOUF, Op.cit, P 90. 
مما يتسبب عنه خسائر لرب العمل أكثر من الإضراب المستمر؛ لأنها تعطل سير العمل في الشركة عن طريق تغيير ظروف العمل. (1)

فبالرغم من أن محكمة النقض الفرنسية قد أقرت بمشروعية الإضراب المتقطع، إلا أنها وصفت هذا الإضراب بالتعفى إذا ترتب عليه عدم الانتظام الجسيم للعمل داخل

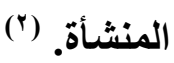

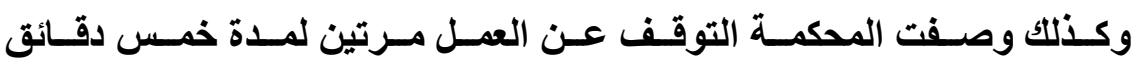

كل سـاعة بالإضراب التعسفى بشرط أن يترتب على ذلك عدم الانتظام الجسيم للعمل

(") بالمنشأة.

وكذلك الحال اعتبرت المحكمة التوقف اليومي عن العمل لمدد قصيرة لمدة شهر

كامل إضراباً تعسفيَّا إذا أدى لإضطراب جسيم داخل مكان العمل. (؛)

(1) Cass. Soc, 11 juin 1981, $N^{\circ}$ de pourvoi: 79-42013, Bull. $\mathrm{n}^{\circ} 522$.

- Cass. Soc, 18 avril 1963 , Bull. $n^{\circ}$ 316, et disponible sur: www.legifrance.gouv.fr.

(2) Cass. Soc, 25 janvier 2011, $\mathbf{N}^{\circ}$ de pourvoi: 09-69030, Bull. civ. $\mathrm{V}, \mathrm{n}^{\circ} 28$, Et disponible sur: www.legifrance.gouv.fr

- Cass. Soc, 10 juillet 1991, $\mathbf{N}^{\circ}$ de pourvoi: 89-43147, Bull. civ. $\mathrm{V}, \mathrm{N}^{\circ} 349$, p. 216, Et disponible sur: www.legifrance.gouv.fr

(3) Cass. Soc, 25 février 1988, $\mathrm{N}^{\circ}$ de pourvoi: 85-43293, Bull. civ. $\mathrm{V}, \mathrm{N}^{\circ} 133$, p. 88, Et disponible sur: www.legifrance.gouv.fr

(4) Cass. Soc, 7 avril 1993, $\mathrm{N}^{\circ}$ de pourvoi: 91-16834, Bull. civ. V, $\mathrm{N}^{\circ} 111$, $\mathrm{p}$. 77, Et disponible sur: www.legifrance.gouv.fr 
وقد اعتبرت محكمة النقض أن التوقف عن العمل المتكرر خلال شهرين متتاليين

هو تعسف في ممارسـة الحقى في الإضـراب طالمـا أدى إلى عدم انتظـام العمل داخل

(1) المنشأة.

وعـدم انتظــام العــل المقـصود هنــا ــ والـــى يـؤدى إلـى وصـف الإضــراب

المتقطع بالتعفى - هو عدم الانتظام الجسيم وليس عدم انتظام العمل البسيط، وعدم

الانتظـام الجسيم قد يكون متمـثلا فـى فقدان المنشـأة للعمـلاء تمامـاً بسبب الإضـراب

(ن) المتقطع. (ن)

والسبب في وصف محكمة النضض الفرنسية هذا الإضراب - في بعض الأحيـان-

بالإضراب التعفى هو أن الأضرار المترتبة عليه قد تفوق المصالح المبتغى تحقيقها

ثالثًا عدم مشروعية الصالح التى يرهى صاحب الهق إلى تهقيقها:

ليس من السلوك المسألوف للشخص العـادي أن يسعى إلى تحقيق مصالح غير

مشروعة تحت ستار أنه يستعمل حقاً له، فنلك يعد تعسفاً في استعمال هذا الحق؛ لأنـه.

يهدف من ورائه إلى تحقيق غرض غير مشروع.

(1) Cass. Soc, 26 février 1975, $N^{\circ}$ de pourvoi: 73-40841, Bull. Soc, $\mathrm{n}^{\circ}$ 95, $\mathrm{P}$. 86, Et disponible sur: www.legifrance.gouv.fr

(2) Mathilde CARON, Grève dans le privé, Op.cit.

- Cass. Soc, 4 novembre 1992, $\mathrm{N}^{\circ}$ de pourvoi: 90-41899, Bull. civ. V, $\mathrm{N}^{\circ}$ 529, p. 335, Et disponible sur: www.legifrance.gouv.fr 
فالمطالب التـي يطلبهـا المضربون مـن صـاحب العمل يجب أن تكون مطالب معقولة، فقد يكون الإضراب تعسفياً إذا كانت المطالب التي يطلبها العمال تعسفية، وهى تكون كذلك إذا كاتت من الصعب تلبيتها من قبل صاحب العمل، أو كاتت مطالبات لا تفيد العمال ولا تعود عليهم بنفع، فالمطالب التي لا تحقق مصلحة حقيقية للعمال تعد مطالب

وهمية غير مشروعه، حتى لو كانت في ظاهر ها مطالب مهنية. (') وبالتالي فالإضراب الذى يتضمن مطالب غير معقولـة أو غير نافعة للعمال يعد

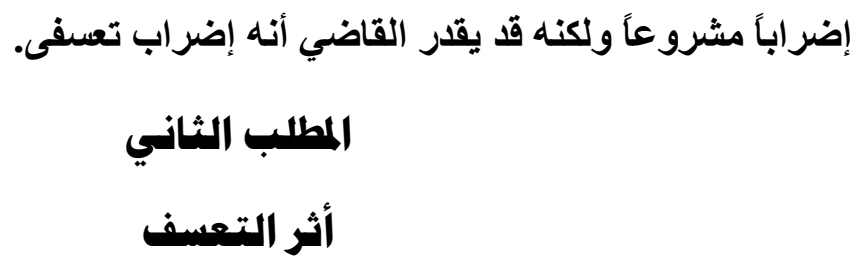

يقع على عاتق قاضى الموضوع تقدير مدى وجود تعسف فى ممارسة الحق فى الإضراب من عدمه وذلك فى ضوء المعايير التى وضعها القـانون المدنى للتعسف فى

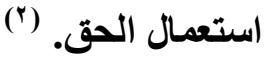
فمن المهم على القاضى أن يحدد اللحظة التى تحول فيها الإضراب إلى إضراب تعسفى، بحيث لا يكون العمال مسؤولين عن تعويض الضرر الأى ترتب عن الممارسـة غير التعفية للحق فى الإضراب ويكونون مسؤولين فقط عن تعويض الضرر المترتب عن الممارسة التعسفية لهذا الحق. ويجب أن يُلاحظ الفرق بين التعسف والخطأ، فالاعتداء على حرية العمل للعمـال الآخرين هو خطأ جسيم كما ذكرنا سالفا، ولا يُعد ذلك تعسفاً، كمـا أنها من ناحية أخرى

(1) Birame DIOUF, Op.cit, P 151.

(2) Maxence VERVOORT, Op.cit, P 126.

مجلت البحوث القانونيت والإقتصاديت 
فليس كل ضرر مترتب على الإضراب و يصيب صـاحب العمل يجعل ممارسـة الإضراب ممارسـة تعسفية، لأن الإضـراب غيـر التعسفى مـن الطبيعـي أن يترتب عليـه ضـرر

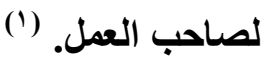

فالقاضي تقع عليه مهمة دقيقة في تحديد مدى اعتبـار ماقـام بـه العامل هو فعل

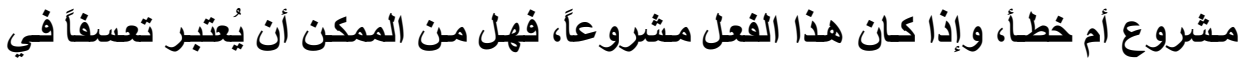

$$
\text { استعمال حق الإضراب أم لا. }
$$

والحقيقة أن هذا الأمـر دقيق جداً؛ لأن اعتبـار فعل مشروع أصـلاً صورة مـن

صور التعسف سيؤدى إلى الحكم على العامل بتعويض الضرر الذي ترتب على هذا

التعسف.

ويجب على القاضي أن يحدد السبب الذي جعله يعتبر هذا الفعل تعسفاً من جاتب

العمال، فإما أن العمال كانت لايهم النية الواضحة للإضرار برب العمل، أو أن المصالح

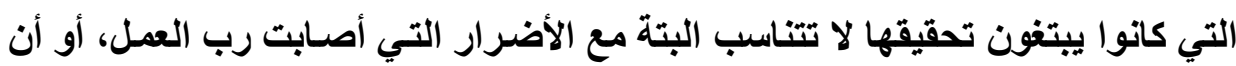

المطالب التي يطلبونها تعد غير معقولة مما يؤدى إلى القول بأن المصلحة المبتغاة هي

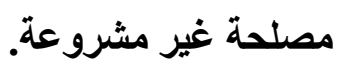

المهـم أن القاضـي يجب أن يحـد بلقـة صـورة التعسف في ممارســة العمـال

للإضراب، وأن يحكم بتعويض الضرر المترتب على هذا التعف فقط وليس تعويض كل الضرر الذي أصاب صاحب العمل، فعلاقة السببية بين الفعل التعفي والضرر يجب أن تتوافر، ويجب على القاضسي أن يحدد بلدة مقدار هذا الضرر الذي ترتب على هذا التعف، بحيث يلتزم العامل بتعويض هذا الضرر فقط دون غيره من أضرار أخرى.

(1) Maxence VERVOORT, Op.cit, P 124.

مجلت البحوث القانونيتة والإقتصاديت 


\section{الخاتمة}

تناولت الدراسة التي بين دفتي البحث موضوع (المسؤولية المدنية عن ممارسة الإضراب عن العمل)، وسوف نستعرض ما توصلت إليه من نتائج وتوصيات.

\section{أولاًا-النتائج:}

1 ـ الإضراب هو حق دستوري، إلا أن هذا الحق ليس حقاً مطلقًا و إنما هو حق مقيد فى ممارسـته بمجموعـه مسن الـشروط والـضوابط التـى تـضمن عـدم التجـاوز فـى ممارستّه.

وضوابط ممارسة الحق فى الإضراب تم النص عليها صراحة فى قانون العمل المصري، فهذا القانون قد نص على مجموعة من الشروطوالإجراءات لممارسـة هذا الحق.

r - من الممكن إثارة المسؤولية المدنية التقصيرية للنقابـة العمالية بالنسبة للأخطاء التي ترتكبها أثناء ممارسة دورها في الإضراب عن العمل إذا كان فعلها يمثل خطأ أصاب الغير بضرر، فالنقابـة العمالية تلعب دوراً محوريـاً في ممارسـة الحق في الإضراب؛ حيث أناط بها القانون الإعلان عن الإضراب وتنظيمه.

r- من الممكن إثارة مسؤولية النقابـة العمالية عن التعسف في ممارسـة الحق في الإضراب وذلك إذا انطبقت حالة من حسلات التعسف في استعمال الحق - التي نصت عليها المادة الخامسة من القانون المدني- على ممارسـة النقابـة للحق في الإضر اب.

ع - من الممكن إثارة المسؤولية المدنية التقصيرية للعمال عن الأخطاء التي يرتكبونها أثناء ممارسة الإضراب عن العمل إذا أدت هذه الأخطاء لأي ضرر يصيب الغير. 
هـ مـن الممكن إثارة مسؤولية العمـال عن التعسف في ممارسـة الحق في الإضراب وذلكا إذا انطبقت حالة من حالات التعفف في استعمال الحق على ممارسـة العمال للحق في الإضراب، وذلك في القانون الفرنسي، أما بالنسبة للقانون المصري فلا يتصور ذلكك لأن العمـال لايحق لهم اللدعوة للإضـراب أو تنظيمسه وإنمـا يتم ذلك بمعرفة النقابة العمالية التي أناط بها القانون ذلك.

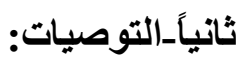
بعد أن انتهينا من هذه الاراسة، فإنتا نوصي بالآتي:1 ـ إنشاء نظـام تـأمين إجبارى من المسؤولية التى تقع على عـاتق العامل، وتتعلق بأضر ار تسبب فيها أثثاء أو بسبب العمل، سواء كـان المضرور هو رب العمل أو هون غيره، بحيث يـخل فيها الأضرار المترتبة عن الإضراب، فيتزم المؤمن بدفع التعويضات التى تترتب فى ذمة العامل فى أية حالة من تلك الأحوال. Y ـ الاهتمام بزيادة وعي العمال بالضوابط التى تنظم الحق فى الإضراب حتى يستقر فى

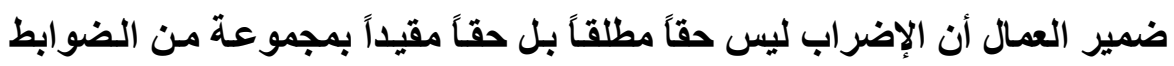
التي يرتب الخروج عليها آثار قانونية قد تصل لالتزام العامل بتعويض المضرور من هذا الإضراب.

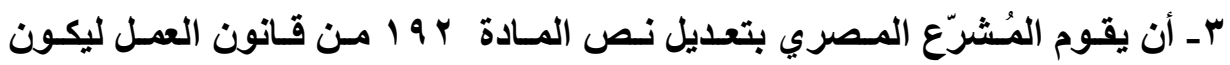
نـــها كـالآتى (للعمـال حق الإضــراب السلمى، ويكون إعلانهـ وتنظيمه من خلال منظماتهم النقابية دفاعا عن مصالحهم المهنية ، وذلك في الحدود وطبقا للضوابط والإجراءات المقررة في هذا القانون). 
ع ـ أن ينص المشرع المصري فى قانون العمل صراحة على حظر الدعوة من قبل

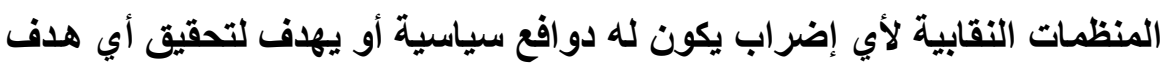

$$
\text { سياسي. }
$$

هـ أن ينص المشرع المصري صراحة على حظر الإضراب المتقطع لما فيه من أضرار

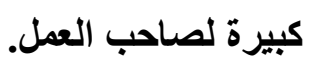

\ـ تفعيل تطبيق نص المادة ؛ ا من قانون النقابات العمالية والتى تنص على التزام

النقابة بإنشاء صندوق خاص لمواجهة آثار الإضراب، حتى يتم الاعتمـاد على التى مـوارد هذا الصندوق للوفـاء بـالتعويض الذَى يحكم بـه القضاء لجبر الأضرار التهاء

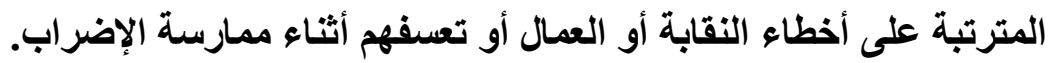




\section{قائمة المراجع}

\section{أولا- هراجع باللغة العربية:}

- إبراهيم الاسوقي أبو الليل، التظيم القانوني لعلاقات العمل الجماعية وفقا للقانون

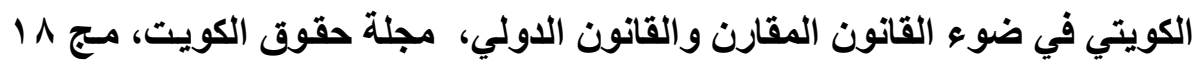

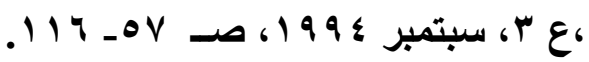

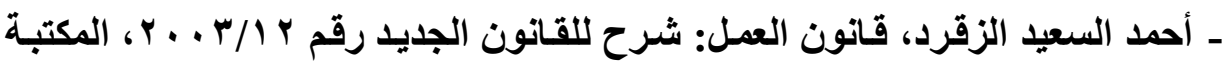

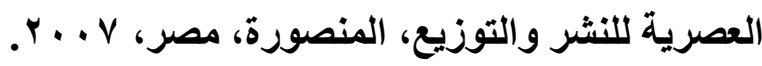

ـ أحمد حسن البرعي، قانون العمل و قضية التنمية الاقتصادية في مصر : دراسـة

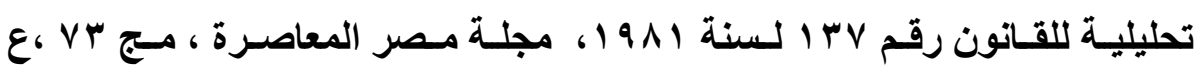

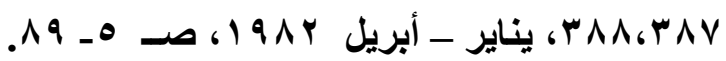

ـ أنـور سـلطان، المـوجز في النظريـة العامـة للالتزام: مصدادر الالتزام، دار الجامعـة

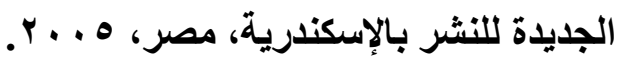

ـ السيد عيد نايل، مدى مشروعية الإضراب وأثره فى العلاقات التعاقدية، مكتبة سيد

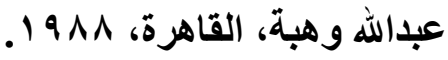

ـ رمضان أبو السعود، مصادر الالتزام، دار الجامعة الجديدة، الإسكندرية، V. . Y. ـ سـليمان مـرقس، الـوافي فـى شـرح القــانون المــنـي: الالتزامــات: الفعـل الـضـار

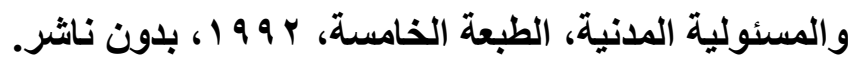
- سمير عبد السيد تناغو، مصادر الالتزام، . . . r، بلون ناشر. ـ صلاح على على حسن، تنظيم الحق فى الإضراب: دراسـة فى التشريعات العربية

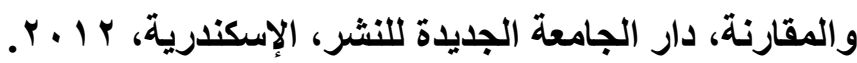


ـ عبد الرزاق أحمد السنهورى، الوسبط في شرح القـانون المدني الجديد، المجلـ

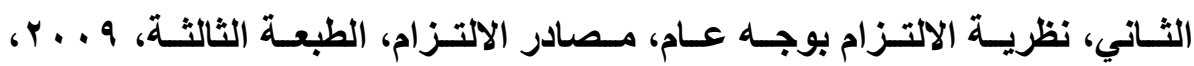

$$
\text { منشورات الحلبي الحقوقية، بيروت. }
$$

ـ عبد الكريم غالي، شروط ممارسة الإضراب في نظر القضاء المغربي، مجلة القانون

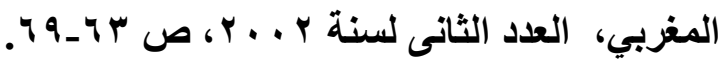

ـ محمد حسين منصور، النظرية العامة للالتزام: مصادر الالتزام، دار الجامعة الجديدة

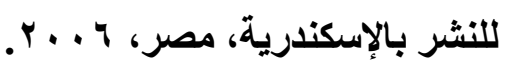

ـ محمد حسين منـصور، قـانون العمل، دار الجامعـة الجديـدة للنشر، الإسـكندرية،

$$
.11
$$

ـ محمود جمال الدين زكى، قانون العمل، مكتبة القاهرة الحديثة، به 19 ـ . ـ مصطفى أحمد أبو عمرو، التظظيم القـانونى لحق الإضـراب فى القـانون المصرى

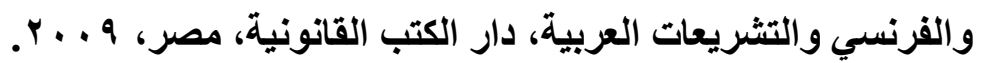

ـ مصطفى أحمد أبو عمـرو، علاقـات العمل الجماعيـة، دار الجامعة الجديدة للنشر، . . . .

ـ مصطفى الجمال، مصادر الالتزام، دار المطبوعات الجامعية بالإسكندرية، 999 1 .

\section{ثانيا- هراجع بالاغة الفرنسية:}

- Adrien LANCIAUX, La responsabilité delictuelle du syndicat à l'occasion d'un conflit collectif, Art disponible sur: www.legavox.fr, La date de mise en ligne est: 28/9/2012.

- Alain SUPIOT, Revisiter les droits d'action collective, Droit Social, 2001, n 7-8, pp. 687-704. 
- Anne-Lise Mougel-ZABEL, Prérogatives et responsabilités des institutions du personnel d'entreprise : contribution à la théorie des droits-fonctions, Thèse Présentée pour l'obtention du grade de Docteur en droit, Faculté de droit, université paris Est, 2010.

- Antoine JEAMMAUD, Les principes dans le droit français du travail, Droit social, Dalloz, 1982.

- Birame DIOUF, Les Responsabilités à l'occasion des conflits collectifs de travail : une étude du droit sénégalais des conflits collectifs à la lumière du droit français, Thèse pour le Doctorat d'Etat en droit, Fac de Droit, Univ de CergyPontoise, 2010.

- Blaise HENRY et Chaumette PATRICK, Chronique de Droit social, en: Revue juridique de l'Ouest, 1989-3, pp. 479-492.

- Brill-Venkatasamy TARA, La prévention des dommages et la cessation de la situation illicite en matière de conflits collectifs du travail : comparaison des droits anglais et français, en: Revue internationale de droit comparé, Vol. 46, $\mathrm{N}^{\circ} 4$ ، Octobredécembre 1994, pp. 1107-1131.

- Cathy NEUBAUER, L'abus du droit de grève, Art disponible sur:www.village-justice.com/articles/abus-droit-greve, $18612 . \mathrm{h}$ tml, La date de mise en ligne est: 5 janvier 2015. 
- Céline LAURICHESSE, La grève en droit international privé, Thèse Pour obtenir le grade de Docteur, Faculté de droit et de science politique, Université de Bourgogne, 2014.

- Christophe RADÉ, « Liberté, égalité, responsabilité » dans la jurisprudence du Conseil constitutionnel, Cahiers du Conseil constitutionnel, $n^{\circ} 16$, juin 2004.

- Clara SOUDAN, La Grève: étude comparative en droit français et en droit italien, Art disponible sur; www.uparis10.fr, La date de mise en ligne est: 14/02/2013.

- Didier Le PRADO, Les fondements constitutionnels et juridiques d'un droit à la réparation du préjudice corporel, Art disponible sur: www.courdecassation.fr, La date de mise en ligne est: 05-12-2006.

- Francisco Mananga, L'exercice du droit de grève et du droit de retrait par les personnels du secteur social et médico-social : une question d'équité, Journal du droit des jeunes, 2009/9, n ○289, p. 33-39.

- Gaston NADEAU, Le statut juridique du salarié-gréviste Québécois, Presses de l'Université Laval, québec, 1981.

- Jacques Le GOFF, Droit du travail et société: Les relations collectives du travail, PUR, 2002. 
- Jean DEPREZ, Grève de solidarité et pouvoir sanctionnateur du chef d'entreprise: vers un assouplissement des conditions de licéité de la grève de solidarité?, Rev Droit social, $\mathrm{N}^{\circ} 2, \mathrm{P}$ 143-152, février 1988.

- Jean MOULY, Droit du travail, éd Breal, Paris, 4 éd, 2008.

- Jean SAVATIER, L'irrecevabilité de l'action civile exercée par l'employeur devant les tribunaux répressifs pour entrave à la liberté du travail, D.S, 1981.

- Jean-Emmanuel RAY, Droit du travail: droit vivant, éd LIAISONS, paris, 17 éd, 2009.

- Jean-Pierre Marguénaud et Jean Mouly, La Cour européenne des droits de l'homme à la conquête du droit de grève, RDT, 2009, P 499.

- Jennifer PARASSOL, Le droit de grève, Art disponible sur: www.blogdegerardpicovschi.com, la date de mise en ligne est: 9 novembre 2006.

- Joël CAVALLINI, Une action collective licite en droit interne peut être contraire à la liberté d'établissement consacrée par le traité de Rome, JCP S, 5 Février 2008, $n^{\circ} 6$.

- Mathilde CARON, Grève dans le privé : conséquences pour les salariés, Les Cahiers Lamy, La revue des comités d'entreprise , ${ }^{\circ} 121,25 / 12 / 2012$. 
- Maxence VERVOORT, L'exercice du droit de grève dans le secteur privé, Thèse Pour obtenir le grade de Docteur en Droit, Faculté de droit et de science politique, Université de nice sophia-antipolis, 2015.

- Maxime BAILLY, Essai sur le droit penal des conflits collectifs du travail, Thèse, Fac de Droit et de Science Politique d'Aix-Marseille, UNIV PAUL CEZANNE - AIXMARSEILLE III, 2011.

- Michel de PONCINS, Le tabou du droit de grève, Le Québécois Libre, 15 février 2012, $\mathrm{N}^{\circ}$ 297, disponible sur:www.quebecoislibre.org.

- Nicolas MOLFESSIS, Sur trois facettes de la jurisprudence du Conseil constitutionnel, Les Nouveaux Cahiers du Conseil constitutionnel, 2011/2, ${ }^{\circ}{ }^{\circ}$ 31, p. 5-19.

- Nicolas MOLFESSIS, Le Conseil constitutionnel et le droit privé, Ed L.G.D.J, 1998.

- Paul DURAND, La Grève et le lock-out en droit français, en Collection du droit du travail: Le droit du travail dans la communauté, Luxembourg, 1961.

- Pauline DISDIER, Les problèmes de responsabilité liés au droit de grève, Art disponible sur: www.comiteentreprises.eu, la date de mise en ligne est: 17 octobre 2012. 
- Roger LATOURNERIE, Le droit français de la grève: étude théorique et pratique,Paris, Ed Sirey, 1972.

- Vincent Neuprez, Michel Deprez, Contrats de travail: l'essentiel, éd edipro, Belgique, 2013.

- Yacouba SANGARE, Les Sanctions en Droit du travail : étude comparative du droit français et du droit malien, thèse pour obtenir le grade de docteur d'etat en droit, faculté de droit, université de Cergy-Pontoise, 2012.

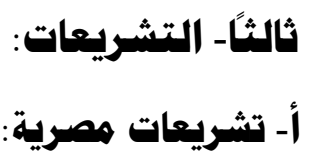

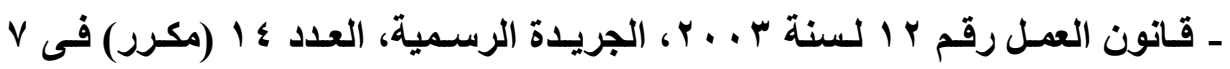

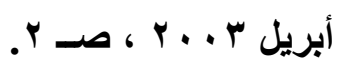

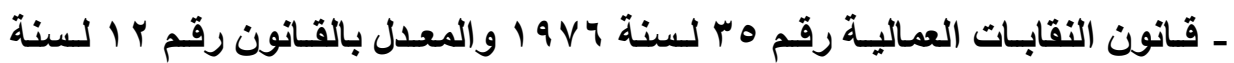

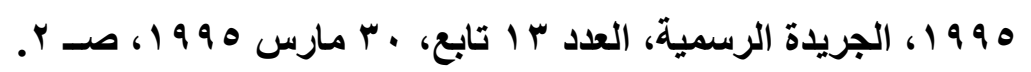

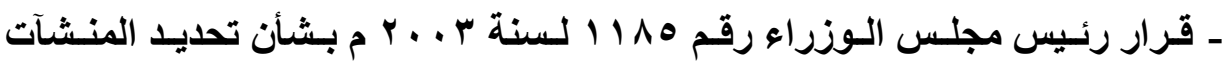

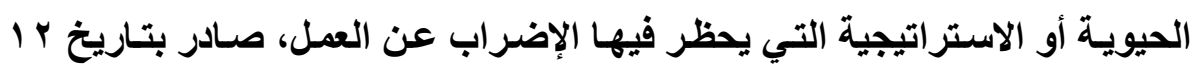

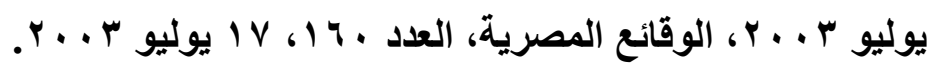

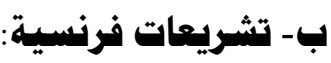

- Code du travail, Version consolidée au 1 février 2017, disponible sur: www.legifrance.gouv.fr 


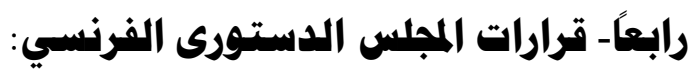

- CC, décision no 2012-650 DC du 15 mars 2012, J.O du 20 mars 2012, p 5028, texte $n^{\circ} 4$ Recueil, p. 149, et disponible sur: www.conseil-constitutionnel.fr.

- CC, décision $\mathrm{n}^{\circ}$ 01645, 7 juillet 1950, RCC, p. 426, et disponible sur : $\underline{\text { ww.conseil-constitutionnel.fr }}$

- CC, décision n ${ }^{\circ}$ 82- 144, 22 Oct 1982, RCC, p. 61, et disponible sur : http://www.conseil-constitutionnel.fr.

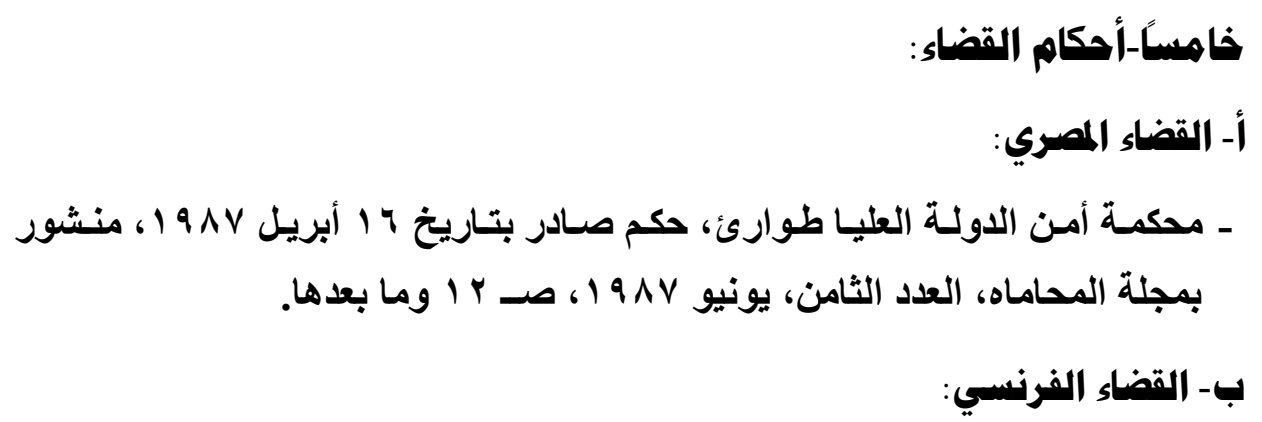

- Cass. Soc, 18 janvier 2017, $N^{\circ}$ de pourvoi: 15-22428 15-22430 15-22431 15-22432 15-22433 15-22434 15-22435 15-22436 15 22437 15-22438, Non publié au bulletin, disponible sur: www.legifrance.gouv.fr.

- Cass. Soc, 18 janvier 2017, $\mathrm{N}^{\circ}$ de pourvoi: 15-19309, Non publié au bulletin, et disponible sur: www.legifrance.gouv.fr

- Cass. Soc, 12 janvier 2016, $N^{\circ}$ de pourvoi: 14-10668, Non publié au bulletin, et disponible sur: www.legifrance.gouv.fr. 
- Cass. Soc, 30 juin 2015, $\mathbf{N}^{\circ}$ de pourvoi: 14-11077, disponible sur: www.legifrance.gouv.fr.

- Cass. Soc, 22 octobre 2014, $N^{\circ}$ de pourvoi: 13-19858 13-19859 13-19860, Bull.civ $V, n^{\circ}$ 246. Et disponible sur: www.legifrance.gouv.fr

- Cass. Soc, 2 juillet 2014, $\mathrm{N}^{\circ}$ de pourvoi: 13-12562, Bull.civ, $\mathrm{V}$, $n^{\circ} 158$, et disponible sur: www.legifrance.gouv.fr

- Cass. Soc, 8 octobre 2014, $\mathrm{N}^{\circ}$ de pourvoi: 13-18873,Bull.civ, V, $n^{\circ} 223$, et disponible sur: www.legifrance.gouv.fr.

- Cass. Soc, 9 mai 2012, $\mathrm{N}^{\circ}$ de pourvoi: 10-24307, Bull.civ, $\mathrm{V}, \mathrm{n}^{\circ}$ 131, et disponible sur: www.legifrance.gouv.fr.

- Cass. Soc, 9 octobre 2012, $\mathrm{N}^{\circ}$ de pourvoi: 11-17829, Bull.civ, $\mathrm{V}, \mathrm{n}^{\circ} \mathbf{2 5 3}$, et disponible sur: www.legifrance.gouv.fr.

- Cass. Soc, 25 janvier 2011, $N^{\circ}$ de pourvoi: 09-69030, Bull. civ. $\mathrm{V}, \mathrm{n}^{\circ} 28$, Et disponible sur: www.legifrance.gouv.fr

- Cass. Soc, 5 janvier 2011, $\mathrm{N}^{\circ}$ de pourvoi: 10-10685, Bull.civ $\mathrm{V}$, $N^{\circ} 1$. et disponible sur: www.legifrance.gouv.fr

- Cass. Soc, 9 mars 2011, $N^{\circ}$ de pourvoi: 09-42150, Bull.civ, V, $n^{\circ} 69$, et disponible sur: www.legifrance.gouv.fr.

- Cass. Soc, 10 février 2009, $N^{\circ}$ de pourvoi: 07-43939, Non publié au bulletin, disponible sur: www.legifrance.gouv.fr. 
- Cass. Soc, 21 octobre 2009, $N^{\circ}$ de pourvoi: 08-14490, Bull. civ. $\mathrm{V}, \mathrm{n}^{\circ}$ 225. et disponible sur: www.legifrance.gouv.fr.

- Cass. Soc, 14 mai 2008, $N^{\circ}$ de pourvoi: 06-46095, Non publié au bulletin, disponible sur: www.legifrance.gouv.fr.

- Cass. Soc, 30 janvier 2008, $N^{\circ}$ de pourvoi: 06-21781, Non publié au bulletin, disponible sur: www.legifrance.gouv.fr.

- Cass. Soc, 28 février 2007, $N^{\circ}$ de pourvoi: 06-40944, Bull.civ $\mathrm{V}, \mathrm{N}^{\circ}$ 33. Et disponible sur: www.legifrance.gouv.fr

-Cass. Soc, 23 octobre 2007, $N^{\circ}$ de pourvoi: 06-17802, Bull. civ. $\mathrm{V}, \mathrm{N}^{\circ} \mathbf{1 6 9}$.

- Cass. Soc, 18 septembre 2007, $N^{\circ}$ de pourvoi: 06-41761, Non publié au bulletin, disponible sur: www.legifrance.gouv.fr.

- Cass. CIV 2, 26 octobre 2006, $N^{\circ}$ de pourvoi: 04-11665, Bull. CIV, 2006, II, $\mathrm{n}^{\circ}$ 299, p. 275, et disponible sur: www.legifrance.gouv.fr.

- Cass. Soc, 2 février 2006, $N^{\circ}$ de pourvoi: 04-12336, Bull. civ. $\mathrm{V}, \mathrm{n}^{\circ}$ 52, p. 46.

- Cass. Soc, 22 juin 2004, $N^{\circ}$ de pourvoi: 02-15500 ,Bull.civ, V, $N^{\circ} 174$, p. 164, disponible sur: www.legifrance.gouv.fr.

- Cass. Soc, 29 janvier 2003, $N^{\circ}$ de pourvoi: 00-22290, Non publié au bulletin, disponible sur: www.legifrance.gouv.fr. 
- Cass. Soc, 17 décembre 2003, $\mathrm{N}^{\circ}$ de pourvoi: 01-46251, Bull.civ V, $\mathbf{n}^{\circ} 317, \quad$ p. 319 . et disponible sur: www.legifrance.gouv.fr

- Cass. Soc, 17 décembre 2002, $\mathrm{N}^{\circ}$ de pourvoi: 00-42115 0042136, Bull.civ, $V, N^{\circ} 388$, p. 384, et disponible sur: www.legifrance.gouv.fr.

- Cass. Soc, 15 mai 2001, $N^{\circ}$ de pourvoi: 00-42200, Bull.Civ, $\mathrm{V}, \mathrm{N}^{\circ} 166, \mathrm{p} .131$, et disponible sur: www.legifrance.gouv.fr.

- Cass. Soc, 18 décembre 2001, Bull. civ, $V, n^{\circ}$ 387, p. 311. et disponible sur: www.legifrance.gouv.fr.

- Cass. Soc, 26 janvier 2000, $N^{\circ}$ de pourvoi: 97-15291, Bull.civ, V, $\mathrm{N}^{\circ}$ 38, p. 28, Et disponible sur: www.legifrance.gouv.fr.

- Cass. Soc, 30 mars 1999, $\mathrm{N}^{\circ}$ de pourvoi: 97-41104, Bull.civ, $\mathrm{V}$, $\mathrm{N}^{\circ}$ 140, p. 101. Et disponible sur: $\underline{\text { www.legifrance.gouv.fr }}$

- Cass. Soc, 31 mars 1998, $N^{\circ}$ de pourvoi: 95-42086, Bull.civ, $\mathrm{V}, \mathrm{N}^{\circ} 180$, p. 131, disponible sur: www.legifrance.gouv.fr.

- Cass. Soc, 25 février 1998, $N^{\circ}$ de pourvoi: 95-45457, Non publié au bulletin, disponible sur: www.legifrance.gouv.fr

- Cass. Soc, 18 juin 1996, Bull. civ, V, No 243 p. 171. disponible sur: www.legifrance.gouv.fr 
- Cass.Soc, 13 novembre 1996, $\mathrm{N}^{\circ}$ de pourvoi: 93-42247, Bull civ. 1996, $\mathrm{V}, \quad \mathrm{N}^{\circ} 379, \quad$ p. 272 . disponible sur: www.legifrance.gouv.fr

- Cass. Soc, 17 juillet 1996, $\mathrm{N}^{\circ}$ de pourvoi: 94-42964, Et disponible sur: www.legifrance.gouv.fr

- Cass. Soc, 19 novembre 1996, $\mathrm{N}^{\circ}$ de pourvoi: 94-42631 9442635, Bull.civ V, $N^{\circ}$ 391, p. 280. et disponible sur: www.legifrance.gouv.fr

- Cass. Soc, 7 juin 1995, $\mathrm{N}^{\circ}$ de pourvoi: 93-43895, Bull.civ V, $\mathrm{N}^{\circ}$ 179, p. 131. et disponible sur: www.legifrance.gouv.fr.

- Cass.Soc, 29 mars 1995, $\mathrm{N}^{\circ}$ de pourvoi: 93-41863, Bull.civ, $1995 \mathrm{~V}, \mathrm{~N}^{\circ} 111$, p. 79, disponible sur: www.legifrance.gouv.fr.

- Cass. Soc, 7 juin 1995, $N^{\circ}$ de pourvoi: 93-42789, Bull. Civ, V, $\mathrm{N}^{\circ} 181$, p. 133. et disponible sur: www.legifrance.gouv.fr.

- Cass. Soc, 22 novembre 1995, $\mathrm{N}^{\circ}$ de pourvoi: 93-44017, Bull.civ V, $\mathbf{N}^{\circ}$ 307, $\mathbf{p} 220$ et disponible sur: www.legifrance.gouv.fr

- Cass. Soc, 7 juin 1995, $\mathrm{N}^{\circ}$ de pourvoi: 93-46448, Bull.civ V, $N^{\circ} 180$, p. 132. Et disponible sur: www.legifrance.gouv.fr

- Cass. Soc, 18 janvier 1995, $N^{\circ}$ de pourvoi: 91-10476, Bull.civ, $\mathrm{V}, \mathrm{N}^{\circ} 27$, p. 18, Et disponible sur: www.legifrance.gouv.fr. 
- Cass. Soc, 23 mai 1995, $N^{\circ}$ de pourvoi: 93-45159, Non publié au bulletin, disponible sur: www.legifrance.gouv.fr.

- Cass. Soc, 5 juillet 1995, $N^{\circ}$ de pourvoi: 93-46108, Non publié au bulletin, disponible sur: www.legifrance.gouv.fr.

- Cass. Soc, 19 octobre 1994, $N^{\circ}$ de pourvoi: 92-11795, Non publié au bulletin, disponible sur: www.legifrance.gouv.fr.

- Cass. Soc. 19 octobre 1994, $\mathrm{N}^{\circ}$ de pourvoi: 91-20292, Bull.Civ. $\mathrm{V}, \mathrm{N}^{\circ} 281$ p. 190, et disponible sur: www.legifrance.gouv.fr.

- Cass. Soc, 16 novembre 1993, № de pourvoi: 91-41024, Bull civ, $\mathrm{V}, \quad \mathrm{N}^{\circ} 268, \quad$. 183 , et disponible sur: www.legifrance.gouv.fr.

- Cass. Soc, 7 avril 1993, $N^{\circ}$ de pourvoi: 91-16834, Bull. civ. V, $N^{\circ} 111$, p. 77, Et disponible sur: www.legifrance.gouv.fr

- Cass. Soc, 13 janvier 1993, $\mathrm{N}^{\circ}$ de pourvoi: 90-45760, Bull civ, $\mathrm{V}, \mathrm{N}^{\circ} 7$, p. 5, et disponible sur: www.legifrance.gouv.fr.

- Cass. Soc, 4 novembre 1992, $N^{\circ}$ de pourvoi: 90-41899, Bull. civ. $\mathrm{V}, \quad \mathrm{N}^{\circ} 529, \quad$ p. $335, \quad \mathrm{Et}$ disponible sur: www.legifrance.gouv.fr

- Cass. Soc, 22 janvier 1992, $\mathrm{N}^{\circ}$ de pourvoi: 90-44249, Bull civ, $\mathrm{V}, \mathrm{N}^{\circ} 19, \mathrm{p} .12$, et disponible sur: www.legifrance.gouv.fr. 
- Cass. Soc, 16 décembre 1992, $\mathrm{N}^{\circ}$ de pourvoi: 91-41215, Bull.civ, V, $\mathrm{N}^{\circ}$ 592, p. 373. et disponible sur: www.legifrance.gouv.fr.

- Cass. Soc, 10 juillet 1991, $\mathrm{N}^{\circ}$ de pourvoi: 89-43147, Bull. civ. V, $\mathrm{N}^{\circ} 349$, p. 216, Et disponible sur: $\underline{\text { www.legifrance.gouv.fr }}$

- Cass. Soc, 30 janvier 1991, $\mathbf{N}^{\circ}$ de pourvoi: 89-17332, Bull.civ, $\mathrm{V}, \mathrm{N}^{\circ} 40$, p. 25, Et disponible sur: www.legifrance.gouv.fr.

- Cass. Soc. 20 février 1991, $N^{\circ}$ de pourvoi: 87-41016, Bull. civ, $\mathrm{V}, \mathrm{n}^{\circ}$ 89, p. 54. Et disponible sur: www.legifrance.gouv.fr.

- Cass. soc, 19 déc 1990, $N^{\circ}$ de pourvoi: 89-14576: Bull. Civ, $\mathrm{V}, \mathrm{N}^{\circ} 698, \mathrm{p} .421$, et disponible sur: www.legifrance.gouv.fr.

- Cass. Soc, 17 juillet 1990, $\mathrm{N}^{\circ}$ de pourvoi: 88-11937, Bull.CIV, V, $N^{\circ} 375$, p. 224, disponible sur: www.legifrance.gouv.fr.

- Cass. Soc, 7 février 1990, $N^{\circ}$ de pourvoi: 87-43566 87-44473 87-44488, Bull.civ $V$, $N^{\circ} 42$, p. 27. et disponible sur: www.legifrance.gouv.fr

- Cass. Soc, 21 juin 1989, $\mathrm{N}^{\circ}$ de pourvoi: 88-44240, Bull.civ V, $N^{\circ} 457$, p. 278. et disponible sur: www.legifrance.gouv.fr

- Cass. Soc, 11 juillet 1989, $N^{\circ}$ de pourvoi: 87-40727, Bull.civ V, $\mathrm{N}^{\circ}$ 509, p. 308. et disponible sur: www.legifrance.gouv.fr

- Cass. Soc, 9 mars 1989, $N^{\circ}$ de pourvoi: 87-40131, Bull.civ, V, $\mathrm{N}^{\circ} 196$, p. 116, et disponible sur: www.legifrance.gouv.fr. 
- Cass. Soc, 6 juin 1989, $\mathrm{N}^{\circ}$ de pourvoi: 87-40738, Bull.Civ, V, $\mathrm{N}^{\circ} 425$, p. 257, et disponible sur: www.legifrance.gouv.fr.

- Cass. Soc, 30 mai 1989, $n^{\circ}$ 86-16765, Bull.civ, V. n 405, p. 244, et disponible sur: www.legifrance.gouv.fr.

- Cass. Soc, 5 décembre 1989, $N^{\circ}$ de pourvoi: 86-44301, Bull civ, $\mathrm{V}, \mathrm{N}^{\circ} 693$, p. 417, et disponible sur: www.legifrance.gouv.fr.

- Cass. Soc, 24 mars 1988, $N^{\circ}$ de pourvoi: 85-43604, Non publié au bulletin. disponible sur: www.legifrance.gouv.fr

- Cass. Soc, 23 juin 1988, $N^{\circ}$ de pourvoi: 86-12327, Non publié au bulletin, disponible sur: www.legifrance.gouv.fr.

- Cass. Soc, 25 février 1988, $\mathbf{N}^{\circ}$ de pourvoi: 85-43293, Bull. civ. V, $\mathrm{N}^{\circ}$ 133, p. 88, Et disponible sur: www.legifrance.gouv.fr

- Cass.Soc, 17 décembre 1987, $N^{\circ}$ de pourvoi: 84-44339, Non publié au bulletin, disponible sur: www.legifrance.gouv.fr.

- Cass. Soc, 25 juin 1987, $\mathrm{N}^{\circ}$ de pourvoi: 85-40250, Bull civ , V, $\mathrm{N}^{\circ} 420$, p. 266, et disponible sur: www.legifrance.gouv.fr.

- Cass. crim, 15 mai 1987, $\mathrm{N}^{\circ}$ de pourvoi: 86-91015, Bull. crim 1987, $\mathrm{N}^{\circ} 198, \quad$ p. 533 , et disponible sur: www.legifrance.gouv.fr.

- Cass. Soc, 21 janvier 1987, $N^{\circ}$ de pourvoi: 85-13295, Bull.CIV, $\mathrm{V}, \mathrm{N}^{\circ} 27, \mathrm{p} .15$, et disponible sur: www.legifrance.gouv.fr. 
- Cass. Soc, 30 avril 1987, $N^{\circ}$ de pourvoi: 84-41871 84-41873 8442370, Bull civ, $\mathrm{V}$, $\mathrm{N}^{\circ}$ 238, p. 152, et disponible sur: www.legifrance.gouv.fr.

- Cass. Soc, 10 décembre 1986, $N^{\circ}$ de pourvoi: 83-41502, Bull.civ V, $\mathbf{N}^{\circ}$ 585, p. 444. Et disponible sur: www.legifrance.gouv.fr

- Cass. Soc, 27 novembre 1985, $N^{\circ}$ de pourvoi: 82-43649, Bull.civ IV, $\mathbf{n}^{\circ}$ 559, p. 405. et disponible sur: www.legifrance.gouv.fr

- Cass. Soc, 7 novembre 1984, $\mathrm{N}^{\circ}$ de pourvoi: 82-41441, Bull.civ $\mathrm{V}, \mathrm{N}^{\circ}$ 418. et disponible sur: $\underline{\text { ww.legifrance.gouv.fr }}$

- Cass. Soc, 26 juillet 1984, $n^{\circ}$ 82-14355, Bull.civ, V, $n^{\circ} 331$, et disponible sur: www.legifrance.gouv.fr.

- Cass. Soc, 8 novembre 1984, $N^{\circ}$ de pourvoi: 82-14816, Bull.civ, V, $n^{\circ}$ 423, Et disponible sur: www.legifrance.gouv.fr.

- Cass. Soc, 8 décembre 1983, $N^{\circ}$ de pourvoi: 81-14238, Bull.soc, $n^{\circ}$ 598, et disponible sur: www.legifrance.gouv.fr

- Cass. Soc, 8 décembre 1983, $n^{\circ}$ 80-14322, Bull.civ, $V, n^{\circ} 602$, et disponible sur: www.legifrance.gouv.fr.

- Cass. Soc, 14 janvier 1982, $\mathrm{N}^{\circ}$ de pourvoi: 79-42669, Bull.soc $n^{\circ} 16$, et disponible sur: www.legifrance.gouv.fr. 
- Cass. Soc, 9 novembre 1982, $\mathrm{N}^{\circ}$ de pourvoi: 80-13958 8014046 80-14097, Bull.Soc, $N^{\circ} 614$, et disponible sur: www.legifrance.gouv.fr.

- Cass. Soc, 9 novembre 1982, $\mathrm{N}^{\circ}$ de pourvoi: 80-16929, Bull.soc, $\mathrm{N}^{\circ} 615$, Et disponible sur: www.legifrance.gouv.fr.

- Cass. crim, 20 avril 1982, Non publié au bulletin, disponible sur: www.legifrance.gouv.fr

- Cass. Soc, 11 juin 1981, № de pourvoi: 79-42013 79-42023, Bull.civ, $n^{\circ}$ 522, Et disponible sur: www.legifrance.gouv.fr

- Cass. Soc, 26 février 1981, $N^{\circ}$ de pourvoi: 79-41359 79-41376, Bull.Soc, $n^{\circ}$ 161, Et disponible sur: www.legifrance.gouv.fr

- Cass. crim, 27 novembre 1979, № de pourvoi: 78-93150, Bull. crim 1987, $n^{\circ} 339$, et disponible sur: www.legifrance.gouv.fr.

- Cass. soc. 25 octobre 1979, $\mathrm{n}^{\circ}$ 78-13528, Bull.Soc, $n^{\circ}$ 786. et disponible sur: www.legifrance.gouv.fr.

- Cass. Soc, 1 février 1978, $\mathrm{N}^{\circ}$ de pourvoi: 76-40273, Bull. soc, $n^{\circ} 73$, P. 53, et disponible sur: www.legifrance.gouv.fr.

- Cass. Soc, 26 février 1975, $\mathrm{N}^{\circ}$ de pourvoi: 73-40841, Bull. Soc, $n^{\circ}$ 95, P. 86, Et disponible sur: www.legifrance.gouv.fr

- Cass. Soc, 8 avril 1974, $N^{\circ}$ de pourvoi: 73-40450, Bull.civ V, $n^{\circ} 223$, P. 211. Et disponible sur: www.legifrance.gouv.fr

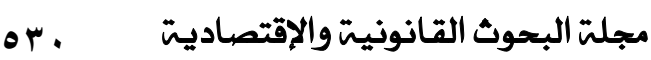


- Cass. Soc, 8 février 1972, $N^{\circ}$ de pourvoi: 71-40285, Bull.soc, $\mathbf{n}^{\circ}$ 113, P. 105. et disponible sur: www.legifrance.gouv.fr

- Cass. Soc, 30 mars 1971, $N^{\circ}$ de pourvoi: 69-40333, Bull.civ V, $N^{\circ} 265$ P. 221. et disponible sur: www.legifrance.gouv.fr

- Cass. Crim, 23 octobre 1969, $\mathrm{N}^{\circ}$ de pourvoi: 68-91860, Bull. Crim, $n^{\circ} 267$, et disponible sur: www.legifrance.gouv.fr.

- Cass. Soc, 23 janvier. 1969, Bull. civ. V, p. 41, n50. et disponible sur: www.legifrance.gouv.fr.

- Cass.Soc, 21 juin 1967, Bull. Civ, $n^{\circ}$ 498. disponible sur: www.legifrance.gouv.fr.

- Cass. Soc, 4 mai 1966, $N^{\circ}$ de pourvoi: 82-41441, Bull.civ V, $N^{\circ}$ 411, p 347. et disponible sur: www.legifrance.gouv.fr

- Cass. Soc, 16 juillet 1964, , Bull.Civ.IV, n ${ }^{\circ}$ 620, p 508, et disponible sur: www.legifrance.gouv.fr.

- Cass. Soc, 15 janvier 1964, Bull.Civ. $n^{\circ}$ 47, et disponible sur: www.legifrance.gouv.fr.

- Cass. Soc, 18 avril 1963 , Bull. $n^{\circ}$ 316, et disponible sur: www.legifrance.gouv.fr.

- Cass.Soc, 3 octobre 1963, Bull. civ. IV, p. 534, n $^{\circ} 645$. Et disponible sur: www.legifrance.gouv.fr.

- Cass. Soc, 13 décembre 1962, Bull.civ, IV, n 904, Et disponible sur: www.legifrance.gouv.fr. 
د/سامع عبد الواحد التهامى

العدد 79 ( أغسطس r.19)

- Cass. Soc, 10 octobre 1962, Bull. Civ, n 702 . Et disponible sur: www.legifrance.gouv.fr

- Cass. Soc, 10 mars 1961, Bull.soc, $n^{\circ}$ 333, et disponible sur: www.legifrance.gouv.fr.

- Cass. Soc, 1 mars 1961, Bull.soc, $n^{\circ}$ 270, et disponible sur: www.legifrance.gouv.fr.

- Cass. Soc, 14 janvier 1960, Bull. IV, $n^{\circ} \leqslant r$, p. ${ }^{\top} \bullet$. Et disponible sur: www.legifrance.gouv.fr

- Cass. Soc, 5 octobre 1960, Bull.soc, $n^{\circ}$ 818, et disponible sur: www.legifrance.gouv.fr.

- Cass. Soc, 29 janvier 1960, Bull.soc, $n^{\circ} 113$, et disponible sur: www.legifrance.gouv.fr.

- Cass. Soc, 23 mars 1953, $N^{\circ}$ de pourvoi: 53-01398, Bull.soc, ${ }^{\circ}$ 253, P. 188, et disponible sur: www.legifrance.gouv.fr

ج- القضاء الأوروبي:

- CJCE (Gde Ch.), 18 décembre 2007, Laval un Partneri Ltd, C-341/05, disponible sur:

http://ec.europa.eu/dgs/legal_service/arrets/listepartheme_fr.h tm. 


\section{قائمة المفتصرات}

\begin{tabular}{|l|l|}
\hline Art & Article. \\
Bull & Bulletin des arrêts de la cour de cassation. \\
Bull.Civ & Bulletin de la cour de cassation (chambre civile). \\
Bull.Soc & Bulletin des arrêts Cour de Cassation section sociale. \\
C & Contre. \\
Cass & Cour de cassation \\
Cass.Civ & Cour de cassation (chambre civile). \\
Cass. Crim & Cour de cassation (chambre criminelle). \\
Cass.Soc & Cour de cassation (chambre sociale). \\
C.C. & Conseil Constitutionnel. \\
Ch & Chambre. \\
CJCE & Cour de Justice des Communautés Européennes. \\
D.S & Recueil Dalloz Sirey. \\
éd & Edition. \\
edipro & Édition professionnelle (belgique). \\
Fac & Faculté. \\
Ibid & Au même endroit. \\
JCPS & La Semaine Juridique Edition Social. \\
JORF & Journal officiel des lois et décrets. \\
L.G.D.J & Librairie générale de droit et de jurisprudence. \\
No & Numéro. \\
Op.cit & Ouvrage précité. \\
P & Page. \\
\hline
\end{tabular}

مجلت البحوث القانونيت والإقتصاديت 
د/ سامـح عبد الواحد التهامى

العدد 79 ( أغسطس 19 r. ) )

\begin{tabular}{|l|l|}
\hline PUR & Presses universitaires de Rennes. \\
RCC & Recueil des décisions du Conseil constitutionnel. \\
RDT & Revue de droit du travail (Dalloz). \\
Rev & Revue. \\
S & Suivant. \\
T & Tome. \\
Univ & Université. \\
Vol & Volume. \\
عدلد & مدحة \\
\hline
\end{tabular}

مجلتّ البحوث القانونيت والإقتصاديت به 